\title{
Arquitetura da informação pervasiva
}

\author{
Henry P. C. de Oliveira \\ Silvana A. B. G. Vidotti \\ Virgínia Bentes
}

OLIVEIRA, HPC, VIDOTTI, SABG, and BENTES, V. Arquitetura da informação pervasiva [online]. São Paulo: Editora UNESP; São Paulo: Cultura Acadêmica, 2015, 117 p. ISBN 978-857983-667-1. Available from SciELO Books $<$ http://books.scielo.org $>$.

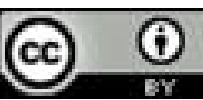

All the contents of this work, except where otherwise noted, is licensed under a Creative Commons Attribution 4.0 International license.

Todo o conteúdo deste trabalho, exceto quando houver ressalva, é publicado sob a licença Creative Commons Atribição $\underline{4.0}$.

Todo el contenido de esta obra, excepto donde se indique lo contrario, está bajo licencia de la licencia Creative Commons Reconocimento 4.0. 


\section{Arquitetura da INFORMAÇÃO PERVASIVA}


CONSELHO EDITORIAL ACADÊMICO

Responsável pela publicação desta obra

\author{
Maria Claudia Cabrini Grácio \\ Edberto Ferneda \\ Helen Castro Silva Casarin \\ José Augusto Chaves Guimarães
}




\section{HENRY P. C. DE OLIVEIRA SILVANA A. B. G. VIDOTTI VIRGÍNIA BENTES}

\section{Arquitetura dA INFORMAÇÃO PERVASIVA}


(C) 2015 Editora Unesp

\section{Cultura Acadêmica}

Praça da Sé, 108

01001-900 - São Paulo - SP

Tel.: (0xx11) 3242-7171

Fax: (0xx11) 3242-7172

www.culturaacademica.com.br

feu@editora.unesp.br

CIP - BRASIL. Catalogação na Publicação

Sindicato Nacional dos Editores de Livros, RJ

O51a

Oliveira, Henry Poncio Cruz de

Arquitetura da informação pervasiva [recurso eletrônico] / Henry Poncio Cruz de Oliveira, Silvana Ap. Borsetti Gregorio Vidotti, Virgínia

Bentes. - 1. ed. - São Paulo : Cultura Acadêmica, 2015.

recurso digital

Formato: epub

Requisitos do sistema: Adobe Acrobat Reader

Modo de acesso: World Wide Web

Inclui bibliografia

ISBN 978-85-7983-667-1 (recurso eletrônico)

1. Sistemas de recuperação da informação - Arquitetura. 2. Tecnologia da informação - Administração. 3. Sistemas de recuperação da informação - Administração. 4. Gerenciamento de recursos da informação. 5. Sistemas de informação gerencial. 6. Livros eletrônicos. I. Vidotti, Silvana Ap. Borsetti Gregorio. II. Pinto, Virgínia Bentes. III. Título.

15-27090

CDD: CDD: 658.4038

CDU: 005.94

Este livro é publicado pelo Programa de Publicações Digitais da Pró-Reitoria de Pós-Graduação da Universidade Estadual Paulista "Júlio de Mesquita Filho" (Unesp)

Editora afiliada:

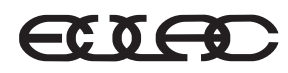

Asociación de Editoriales Universitarias de América Latina y el Caribe

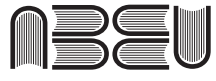

Associação Brasileira de Editoras Universitárias 
Aos nossos familiares, dedicamos. 


\section{Agradecimentos}

Agradecemos às pessoas que contribuíram para a construção desta obra, especialmente à Profa. Fabiana Lazzarin, por nos emprestar suas competências em normalização de textos científicos.

Agradecemos especialmente à Profa. Dra. Ana Alice Rodrigues Pereira Baptista (Universidade do Minho, Porto - Portugal), à Profa. Dra. Silvana Drumond Monteiro (Universidade Estadual de Londrina, Londrina - Brasil), ao Prof. Dr. Guilherme Ataíde Dias (Universidade Federal da Paraíba, João Pessoa - Brasil) e à Profa. Dra. Plácida Leopoldina Ventura Amorim da Costa Santos (Universidade Estadual Paulista - Unesp, Marília - Brasil), pelas contribuições. 


\section{SUMÁRIO}

Prefácio $\quad 11$

1 Notas científicas e tecnológicas 15

2 Arquitetura da informação 43

3 Arquitetura da informação pervasiva 75

Referências 107 


\section{Prefácio}

Prefaciar um livro é uma tarefa que demanda responsabilidade e, principalmente, confiança no conjunto de saberes apresentados na obra. Nesse sentido, não tive nenhuma dúvida em escrever este texto, pois endosso as ideias que são discutidas em Arquitetura da informação pervasiva e sinto-me orgulhoso por assumir essa função de prefaciador.

O resultado final de um texto está diretamente relacionado com a experiência dos autores na abordagem do tema tratado. Os autores deste livro são pesquisadores experientes na área da Ciência da Informação e versados nos diversos temas que orbitam a Arquitetura da Informação. O professor Dr. Henry Poncio Cruz de Oliveira é um jovem pesquisador que tem demonstrado muita competência na área da Arquitetura da Informação - considero-o também um erudito nos mais variados assuntos que emergem a partir do diálogo das tecnologias de informação com a Ciência da Informação. Com relação à Profa. Dra. Silvana Aparecida Borsetti Gregório Vidotti, destaco-a como uma pioneira no trato das interseções da Ciência da Informação com as tecnologias da informação e, possivelmente, é a pesquisadora que mais contribuiu para o estudo e a disseminação da Arquitetura da Informação no Brasil. A Profa. Dra. Virgínia Bentes é pesquisadora e bibliotecária, possui vasta experiência na aplicação 
das tecnologias da informação no fazer bibliotecário - mais especificamente nas atividades relacionadas com a representação da informação. Destaco também seu interesse na aplicação da Arquitetura da Informação no âmbito da saúde.

Esta obra está estruturada em três capítulos. O primeiro contextualiza as dinâmicas sociotecnológicas pertinentes ao mundo contemporâneo. Conceitos interessantes são discutidos e explicados, como a semântica associada a ambientes informacionais digitais e ambientes de informação digital. O livro tem como foco a Arquitetura da Informação Pervasiva, mas também discute a ciência da informação de forma aprofundada em virtude de a informação ser um fenômeno nuclear a todas as atividades humanas, o que contribui para nortear os leitores iniciantes nesta área do conhecimento.

O segundo capítulo apresenta a Arquitetura da Informação sob diversos aspectos. Os autores inicialmente discutem o tema por um viés epistêmico, traçam as suas origens e realizam uma contextualização espaçotemporal. $\mathrm{O}$ capítulo ainda se dedica à discussão da Arquitetura da Informação sob quatro diferentes abordagens - arquitetural, sistêmica, informacional e pervasiva.

O terceiro capítulo dá nome ao livro. O pioneirismo da obra é evidente e os autores foram muito felizes na elaboração deste material. Arriscaria em dizer que em língua portuguesa, até o momento, inexistem outros trabalhos bibliográficos que versem sobre o tema Arquitetura da Informação Pervasiva. Assim, é patente a contribuição que os autores deixam para a Ciência da Informação e a Arquitetura da Informação de uma maneira mais ampla.

A maior parte dos trabalhos existentes sobre a Arquitetura da Informação volta-se para a construção e avaliação de ambientes informacionais digitais que se estruturam sob a égide da abordagem informacional. Isso não tem nenhum problema, mas esses trabalhos não são adequados para abordar os desafios que surgem quando da fusão do ciberespaço - tal qual como proposto por William Gibson - com os espaços informacionais físicos.

Recomendo a leitura de Arquitetura da informação pervasiva não apenas para estudantes, profissionais e pesquisadores que tra- 
balhem com Ciência da Informação e Arquitetura da Informação, mas também para todos que militem em áreas como a ciência da computação, comunicação, arquitetura, design gráfico e outras.

Boa leitura!

Guilherme Ataíde Dias 


\section{1 \\ Notas CientífICAS E teCNOLÓGICAS}

As mudanças tecnológicas consequentes da Revolução Industrial têm modificado o cotidiano de universidades, centros de pesquisa, governos, empresas, bibliotecas, arquivos, museus e demais setores da sociedade. Tais modificações estão vinculadas aos avanços da técnica e da tecnologia, e propiciam a produção e o uso de artefatos tecnológicos cada vez mais integrados ao cotidiano das pessoas. Cresce a produção de ambientes de informação, bem como a interação entre os sujeitos, dos sujeitos com as organizações e entre as próprias organizações. Esses ambientes necessitam ser projetados considerando, além das questões tecnológicas, as necessidades, os comportamentos, a cultura, a história e as subjetividades dos sujeitos que os acessam e usam.

Emerge um movimento tecnológico de integração de ambientes analógicos com ambientes digitais, por meio da criação de camadas informacionais que os intersecionam, facilitando a experiência do sujeito nesses ambientes. Temos visto ainda um fenômeno ecológico em que uma mesma informação deve estar acessível em um ambiente analógico, em um website, em um aplicativo para tablets, em um aplicativo para smartphones ou em uma televisão digital. Compreendemos que essa informação necessita amoldar-se ao contexto e ao dispositivo utilizado para acessá-la, o que torna mais comple- 
xas as questões arquiteturais da informação em cada ambiente, em cada dispositivo e gera a necessidade de repensar a experiência tecnológica para torná-la mais integrada e holística.

Nesse contexto, a Arquitetura da Informação e os aspectos informacionais e tecnológicos que permeiam os setores da sociedade pós-moderna constituem produto de um contínuo processo de evolução histórica e cultural marcado pelo avanço da técnica e pelo desenvolvimento tecnológico que subsidia a construção de ferramentas, produtos e processos informacionais.

Essa realidade suscitou a realização deste livro como contributo à área de Ciência da Informação. A presente obra deriva e ao mesmo tempo revisita o processo de pesquisa que gerou a tese de doutorado intitulada Arquitetura da informação pervasiva, de autoria de Henry Pôncio Cruz de Oliveira. Em função das demandas informacionais e arquiteturais solicitadas atualmente, a referida pesquisa problematizou a Arquitetura da Informação do ponto de vista teórico-metodológico. A partir de um olhar criterioso sobre o objeto de investigação, utilizou-se uma metodologia fenomenológica-sistêmica para construir um conhecimento teórico sobre a Arquitetura da Informação Pervasiva.

O presente livro visa a apresentar os fundamentos teóricos de uma Arquitetura da Informação Pervasiva enquanto demanda informacional e tecnológica da pós-modernidade. Este livro é um produto científico que contribuirá diretamente com pesquisas em desenvolvimento na área de Ciência da Informação, com apoio do CNPq, ${ }^{1}$ que envolvem a Universidade Federal da Paraíba (UFPB), a Universidade Estadual Paulista "Júlio de Mesquita Filho" (Unesp) e a Universidade Federal do Ceará (UFC).

1 Projeto MCTI/CNPQ/Universal Processo n. 459.853/2014-7. Projeto PQ n. 312.544/2013-8. Projeto MCTI/CNPQ/Universal Processo n. 486.147/2011-8. Edital CNPq - CHSSA Processo n. 407.149/2012-0. PQ 308443/2010-1. PQ- 307299/2012-0. Projeto MCTI/CNPQ/Universal 456624/2014-7. Edital CNPq - Humanas Processo n. 406.054/2012-6. 


\section{Cientificidade pós-moderna}

As mudanças sociotecnológicas que se intensificaram historicamente têm provocado um debate analítico e terminológico para classificar/categorizar a sociedade atual. Nesse sentido, o termo pós-modernidade tem sido adotado como expressão para referenciar, representar e caracterizar a sociedade atual, bem como as modificações ocorridas nas últimas quatro décadas do século XX. (Bauman, 1997; Hall, 2006; Habermas, 1990; Lyotard, 1993).

Categorizar a sociedade em função de características que diferenciam o atual arranjo político, econômico, social e cultural é um desafio enfrentado por diversos estudiosos e gera, além da expressão pós-modernidade, expressões como sociedade da informação (Bell, 1973), sociedade do conhecimento (Squirra, 2005), sociedade da aprendizagem (Pozo, 2004), modernidade líquida (Bauman, 2003), hipermodernidade (Lipovetsky; Charles, 2004), modernidade tardia (Giddens, 2002), aldeia global (Mcluhan, 1972), entre outras.

Segundo Oliveira (2014), essas terminologias são tentativas teóricas de categorizar e diferenciar com certo nível de precisão um contexto antropológico e sociocultural marcado por fortes mudanças no campo das ciências, das artes, das tecnologias, das identidades, das subjetividades e que produzem novas concepções de espaço, tempo e movimento. Diante do rol de possibilidades teórico-conceituais, defendemos o termo sociedade pós-moderna, em função das aplicações da noção de pós-modernidade na Ciência da Informação e na Arquitetura da Informação, lugares de pesquisa fundamentais para a construção deste livro. Vale salientar que ao adotarmos a pós-modernidade como plano de referência não pretendemos problematizar e discutir as diferentes correntes que descrevem a pós-modernidade, porém nos parece razoável descrever o que compreendemos como pós-modernidade.

O que chamamos de pós-modernidade diz respeito a uma contínua e complexa tentativa de ruptura com as visões iluministas e da Revolução Industrial, que estruturaram o modelo moderno de 
pensar, de fazer ciência, de racionalizar educação, de organizar a sociedade, de disseminar informação e de produzir tecnologia.

Gatti (2005) esclarece que o debate sobre a pós-modernidade intensificou-se a partir da segunda metade do século XX. A autora supracitada assevera que tal século "[...] construiu caminhos históricos da sociedade e de seus conhecimentos que acabaram por problematizar as grandes utopias e modelos de análise produzidos nos séculos anteriores [...]", na consagrada era da modernidade (Gatti, 2005, p.596). Adotar a pós-modernidade como referência discursiva significa contrapor, desconstruir, desamarrar, (re)pensar as noções de tempo e espaço, sujeito e objeto, técnica e tecnologia, objetividade e subjetividade, identidade, arte, ciência e senso comum, rompendo com o modo binarista de categorizar o que se apresenta como realidade.

Para François Lyotard (1993), a pós-modernidade se define pela incredulidade em relação aos metarrelatos, ou seja, pelo rompimento com as grandes narrativas que objetivavam invocar explicações universais, únicas, válidas e correspondentes à realidade.

Entretanto, não é possível falar em ciência pós-moderna sem refletir e delinear as concepções científicas consolidadas na modernidade, o que implica compreender como as ciências se modificam a partir da construção/desconstrução/reconstrução de paradigmas. Kuhn (2003) nos ajuda a compreender que um paradigma é aquilo que os membros de uma comunidade partilham e, inversamente, uma comunidade científica consiste em pessoas que partilham um paradigma. Do ponto de vista etimológico, a palavra paradigma vem da expressão grega paradeigma, que significa: exemplar, mostrar (déiknumi) uma coisa fazendo referência (pará) à outra coisa. Ou seja, o paradigma é um modelo que nos permite ver uma coisa em analogia a outra (Kuhn, 2003).

O pensamento de Kuhn (2003) nos permite compreender que a construção, manutenção e/ou ruptura de paradigmas, concebidos como partilha ideológica dos sujeitos que produzem ciência, é um processo sócio-histórico contínuo e tensionado por questionamentos e tentativas de dar respostas aos problemas relacionados aos 
diversos objetos/fenômenos de investigação. Assim, o que chamamos de modernidade, pós-modernidade ou qualquer outra categorização da sociedade ou da ciência é na realidade um tensionamento de paradigmas que tentam preservar sua validade e fragilizar a validade de outros paradigmas que se apresentem antagonistas (Oliveira, 2014).

O modelo de racionalidade que orienta a ciência moderna firma-se a partir da revolução científica do século XVI propiciada pelo desenvolvimento das ciências naturais. O paradigma moderno propicia a ruptura com os modelos dogmáticos e de autoridade (teocentrismo). As crises social e moral do fim da Idade Média e os vestígios nascentes da sociedade industrial fazem o paradigma moderno avançar no campo científico por meio da produção de um conhecimento baseado na observação sistemática, na objetividade e na experimentação. Em tal perspectiva, a matemática fornece à ciência moderna os requisitos para a análise e estruturação lógica de investigação. Nesse sentido, conhecer está relacionado a quantificar, e o que não pode ser mensurado é cientificamente irrelevante (Santos, 1988). Essa conjuntura se vincula ao pensamento iluminista do século XVIII, cultivando um solo adequado para o surgimento das ideias positivistas, ${ }^{2}$ dominantes na modernidade.

Outro ponto a ser pensado na perspectiva da modernidade é a noção de sujeito, marcada pelas ideias de centralidade, individualidade, integralidade, soberania e racionalidade (Hall, 2006). O sujeito desenhado na ótica moderna e positivista tudo pode conhecer, desde que existam as condições adequadas para a produção deste conhecimento.

2 Este termo foi empregado pela primeira vez por Saint-Simon para designar o método exato das ciências e sua extensão para a filosofia. Foi adotado por Augusto Comte para a sua filosofia e, graças a ele, passou a designar uma grande corrente filosófica que, na segunda metade do século XIX, teve numerosíssimas e variadas manifestações em todos os países do mundo ocidental. A característica do positivismo é a romantização da ciência, sua devoção como único guia da vida individual e social do homem, único conhecimento, única moral, única religião possível (Abbagnano, 2007, p.767). 
O paradigma moderno dinamiza o desenvolvimento das ciências naturais e, em virtude do sucesso da matemática aplicada ao mundo físico, cogita-se sua aplicação em qualquer outro campo de produção do conhecimento. Em tal contexto, especula-se, para os métodos matemáticos e estatísticos, igual sucesso no campo das ciências sociais (Brookes, 1980).

A consequência de tal pretensão é a existência de uma tensão paradigmática no cerne das ciências sociais, produzindo um movimento de oscilação em torno de dois eixos, um de adoção dos pressupostos teórico-metodológicos das ciências naturais e outro de defesa de uma identidade teórico-metodológica própria, justificada pela complexidade dos objetos de investigação das ciências sociais (Oliveira, 2014).

O primeiro eixo funciona como uma possibilidade de elevação e reconhecimento das ciências sociais por meio da adequação aos pressupostos positivistas a partir de uma analogia sistemática feita entre as ciências sociais e as ciências naturais. Nesse sentido, as premissas positivistas aplicadas às ciências sociais entendem que a sociedade é regida por leis invariáveis, independentes da vontade e da ação humana. Defende ainda a existência de uma relação de analogia entre a realidade social e a realidade físico-natural, o que justificaria a utilização dos métodos, conceitos e linguagem oriundos das ciências naturais nas investigações das ciências sociais. Dentro dos contornos modernos, as ciências sociais devem primar pela a observação e pela explicação causal dos fenômenos de forma objetiva, livre de juízos de valor, de noções prévias e de posturas ideológicas (Löwy, 1987).

Embora o modelo de racionalidade científica com pressupostos positivistas da modernidade perdure até os dias de hoje, ele expressa sinais de fragilidade e crise no contexto acadêmico e social. "São hoje muitos e fortes os sinais de que o modelo de racionalidade científica [...] atravessa uma profunda crise [...]” (Santos, 1988, p 54).

O segundo eixo teórico-metodológico que faz oscilar as ciências sociais acredita em uma proposta idiossincrásica, cuja defesa argu- 
mentativa se baseia na tese de que a experiência social e humana é fundamentalmente subjetiva. Por conseguinte, os comportamentos humanos e fenômenos sociais são contrários aos fenômenos naturais (Santos, 1988). Essa visão sugere que os métodos quantitativos cedam lugar aos métodos qualitativos no processo de investigação científica.

A crise do modelo racionalista estabelece um contexto de transição e anúncio de um paradigma emergente, que tem sido denominado pós-modernidade por estar marcado por singularidades que estabelecem diferenças fundamentais em relação ao paradigma moderno (Oliveira, 2014).

Embora não seja trivial superar a modernidade enquanto modelo de racionalidade (Habermas, 1990), a história registra o declínio das relações dicotômicas na produção do conhecimento e emergência de outro paradigma. Segundo Santos (1988), o conhecimento do paradigma emergente tende assim a ser um conhecimento não dualista, um conhecimento que se funda na superação de distinções tão familiares, óbvias e insubstituíveis, como natureza/cultura, natural/artificial, vivo/inanimado, mente/matéria, observador/observado, subjetivo/objetivo, coletivo/individual, animal/pessoa.

Para a pós-modernidade todo conhecimento científico-natural é científico-social, todo conhecimento é total e local, todo conhecimento é autoconhecimento e todo conhecimento científico visa a constituir-se num novo senso comum, o que desconstrói as bases epistêmicas da modernidade (Santos, 1988).

A relação entre ciência e senso comum é outro ponto que merece reflexão. A emergência de um paradigma pós-moderno promove uma revisão, uma ressignificação e uma nova valoração do senso comum.

Estamos de novo regressados à necessidade de perguntar pelas relações entre a ciência e a virtude, pelo valor do conhecimento dito ordinário ou vulgar que nós, sujeitos individuais ou coletivos, criamos e usamos para dar sentido às nossas práticas e que a ciência 
teima em considerar irrelevante, ilusório e falso; e temos finalmente de perguntar pelo papel de todo o conhecimento científico acumulado no enriquecimento ou no empobrecimento prático das nossas vidas, ou seja, pelo contributo positivo ou negativo da ciência para a nossa felicidade. (Santos, 1988, p.47)

A pós-modernidade desconstrói a rigidez identitária do sujeito moderno com certa radicalidade. Para Hall (2006), a globalização influencia na formação das identidades culturais e produz um sujeito pós-moderno desprovido de uma identidade fixa, essencial ou permanente. As identidades são compreendidas como móveis, fluidas, mutáveis e reguladas pelos diversos sistemas culturais que nos entornam. O sujeito desenhado na pós-modernidade é uma tessitura complexa de diversos fragmentos indentitários.

Na compreensão de Santos (1987), as fissuras que temos apresentado em relação ao pensamento moderno tornaram-se mais visíveis justamente em função do grande avanço do conhecimento produzido pela modernidade. A identificação dos limites e das insuficiências estruturais do paradigma científico moderno é o resultado do grande avanço no conhecimento que ele propiciou. $\mathrm{O}$ aprofundamento do conhecimento permitiu ver a fragilidade dos pilares em que ele se funda (Santos, 1987, p.24).

De extrema relevância para os estudiosos da Ciência da Informação é a percepção de que, no interior do que chamamos de pós-modernidade, existe um cenário irreversível de expansão dos mercados informacionais baseados em grandes estruturas de dados que necessitam ser gerenciados/processados por aparatos computacionais e disseminados de forma facilitada pelas estruturas de telecomunicações. Tal processamento de dados permite que a informação digital seja acessada e usada no cotidiano dos sujeitos, dos diversos grupos sociais, das organizações e dos governos (Oliveira, 2014). Trata-se necessariamente de uma revolução tecnológica atrelada a avanços na técnica e na tecnologia. 


\section{Técnica, tecnologia e revolução tecnológica}

Para Castells (1999), uma revolução se anuncia pelo acontecimento de eventos importantes e faz uma marcação espaçotemporal capaz de indicar a proximidade de um novo momento, uma nova era, um novo modelo de sociedade. $\mathrm{O}$ autor defende que no final do século XX presenciamos momentos dessa natureza, o que implicou uma transformação de nossa cultura material por meio de um paradigma tecnológico organizado em torno do desenvolvimento da técnica e das tecnologias, em especial as tecnologias de informação e comunicação.

Tal revolução, justificada por sua penetrabilidade em todas as esferas da atividade humana, promovendo mudanças irreversíveis na economia, na cultura e na sociedade de modo geral, foi construída ao longo da história e pode ser evidenciada no rol de apontamentos históricos (Castells, 1999). Em forma de síntese, apresentamos tais apontamentos históricos por entender que seu traçado se associa às noções de técnica e tecnologia, fundamentais para contextualizar o lugar que a informação e a Arquitetura da Informação ocupam na sociedade pós-moderna.

Uma revolução de natureza tecnológica se vincula a um conjunto de significados atribuídos à técnica e à tecnologia, o que nos impele a distinguir, teoricamente, as categorias supracitadas. Ao tratar do impacto epistemológico da tecnologia, Agazzi (1997) as distingue em função de divergências semânticas e falta de padronização no uso desses termos em diferentes países. Nesse sentido, Agazzi (1997, p.1, tradução nossa) argumenta que

[...] existem idiomas como o inglês, onde se utiliza habitualmente "tecnologia", e praticamente não se usa, salvo em um sentido pouco usual (em geral, para designar as maneiras concretas e especiais de realizar uma determinada operação) a palavra "técnica”. Em espanhol e italiano, assim como em outros idiomas, ao contrário, se utilizam ambos os termos com significado similar. É por isso que me proponho a aproveitar esta dupla possibilidade 
para tomar o termo "técnica" em sentido muito geral e o termo "tecnologia" em um sentido mais particularizado.

Oliveira (2014) assevera que no Brasil também se percebe o efeito polissêmico sobre os termos técnica e tecnologia, inclusive as variações dependem da área do conhecimento que discursa sobre tais categorias. Para explicitar as noções de técnica e tecnologia adotadas neste livro, recorremos às reflexões filosóficas de Evandro Agazzi e do brasileiro Álvaro Vieira Pinto (Agazzi, 1997; Pinto, 2005).

O italiano Evandro Agazzi, discursando num seminário intitulado El Impacto Epistemológico de la Tecnología, na Universidade de Sevilla, argumenta que a técnica diz respeito a um conjunto de conhecimentos eficazes que o homem tem desenvolvido ao longo dos séculos para melhorar seu modo de vida, de modo que a técnica é tão antiga quanto a própria humanidade (Agazzi, 1997). Essa perspectiva dialoga com as noções gregas de téchne encontradas em Platão e em Aristóteles, evidenciando os aspectos materiais da técnica enquanto legado de conhecimentos e habilidades que se adaptam conforme as sociedades se modificam.

Analisando a tecnologia do ponto de vista etimológico, Agazzi (1997) destaca o sufixo "logia" e afirma que "[...] quando aparece o sufixo "logia" se quer indicar a existência de uma certa doutrina elaborada, uma teoria acerca do assunto em questão [...]", nesse caso a técnica (Agazzi, 1997, p.1, tradução nossa). Para Oliveira (2014), a tecnologia diz respeito ao que ocorre no interior da trajetória da técnica ao produzir, sobretudo na civilização ocidental, conhecimentos teóricos hábeis para justificar e viabilizar a replicação de certos aparatos ou modos de fazer, considerados eficazes.

O estudioso Álvaro Vieira Pinto, no livro intitulado O conceito de tecnologia, faz uma crítica que diferencia as tecnologias e a técnica. $\mathrm{O}$ autor recorre à Grécia antiga para investigar raízes semânticas do termo téchne, adverte que tal compreensão não pode ser reduzida a um simples processo ou ao modo de se fazer as coisas. Tal 
reducionismo deve ser evitado, pois consiste em um modo humano de realizar ações maquínicas (Pinto, 2005).

Pinto (2005) assevera que a técnica, de forma alguma, é um tema recente do pensamento filosófico, em nenhuma época e em relação a nenhum objeto o homem deixou de agir tecnicamente. Portanto, o que vemos nos dias atuais não traz nenhum ineditismo sobre a técnica, a não ser a intensificação quantitativa da produção técnica, bem como os impactos observáveis na sociedade. Esclarece ainda que o processo de aceleração da produção técnica é consequência do advento da Revolução Industrial e da consolidação do modelo capitalista de produção.

Para Oliveira (2014), o pensamento de Álvaro Vieira Pinto contribui para a superação da visão simplista de técnica como um simples modus faciendi, ${ }^{3}$ reconhece o homem como sujeito que atua sobre a história por meio da construção de produtos materiais baseados na técnica enquanto artefato histórico. Pinto (2005) também reconhece que o termo tecnologia é marcado pela polissemia, pela ausência de uma definição inequívoca e apresenta algumas possibilidades conceituais.

Nesse sentido, também recorre à análise etimológica e relaciona uma tecnologia às teorias, à ciência, ao estudo, à discussão feita sobre a técnica. Assim, a tecnologia imbrica nas habilidades para o fazer, nas profissões e nos modos gerais de produzir artefatos de forma sistematizada.

Segundo Pinto (2005), há acepção que estabelece uma equivalência direta e objetiva entre tecnologia e técnica, sendo esse sentido adotado com frequência e largamente usado no cotidiano, sobretudo quando é desnecessária uma precisão conceitual maior. Na visão de Oliveira (2014), trata-se de uma noção ingênua e simplista sobre o fenômeno tecnológico.

3 A expressão latina modus faciendi pode ser traduzida como modo de fazer, modo de agir. Disponível em: <http://www.leituradiaria.com.br/pequeno-dicionario-de-expressoes-em-latin/>. Acesso em: 8 mai. 2013. Disponível em: $<$ http://aulete.uol.com.br/modus\%20faciendi>. Acesso em: 8 mai. 2013. 
Outra vertente conceitual, ligada à anterior, trata a tecnologia como "[...] o conjunto de todas as técnicas das quais dispõe uma sociedade, em qualquer fase histórica de seu desenvolvimento [...]" (Pinto, 2005, p.220). Essa acepção é útil para compreender que todas as sociedades são tecnológicas. Ademais, tem sido utilizada largamente para avaliar o grau de avanço das forças produtivas de uma sociedade.

A tecnologia é uma construção teórico-reflexiva realizada sobre a técnica enquanto qualidade do ato produtivo; trata-se de uma ciência da técnica que suscita reflexões epistemológicas sobre os concretos desdobramentos maquínicos na sociedade; é uma construção que se materializa como uma ideologia da técnica, pode produzir dominação, exclusão social, impactar as condições gerais de trabalho, modificar comportamentos e influenciar formas de pensar, executar e avaliar a técnica; é um fenômeno que engloba a técnica, os sujeitos e os produtos tecnológicos como componentes essenciais (Oliveira, 2014).

A tessitura conceitual realizada, neste livro, sobre a técnica e a tecnologia objetivou criar um plano de fundo adequado retomar os apontamentos do sociólogo Manuel Castells sobre a Revolução Tecnológica (Castells, 1999).

Para conceber uma revolução tecnológica centralizada na geração/processamento/transmissão da informação é necessário considerar os efeitos da Revolução Industrial iniciada nos fins do século XVIII e expandida no século XIX. A inserção de tecnologias como a máquina a vapor, fiadeira, Cort na metalurgia, desenvolvimento da eletricidade, produtos químicos com base científica, difusão do telégrafo e invenção do telefone instauraram uma lógica de celeridade nas transformações tecnológicas jamais vista na história (Castells, 1999). Reforçando o caráter revolucionário, o autor supracitado defende que

[...] Foram, de fato, "revoluções" no sentido de que um grande aumento repentino e inesperado de aplicações tecnológicas transformou os processos de produção e distribuição, criou uma enxurrada de novos produtos e mudou de maneira decisiva a localização 
das riquezas e do poder no mundo, que, de repente, ficaram ao alcance dos países e elites capazes de comandar o novo sistema tecnológico. O lado escuro dessa aventura tecnológica é que ela estava irremediavelmente ligada a ambições imperialistas e conflitos interimperialistas. (Castells, 1999, p.71)

Avançando nas mudanças propiciadas pela Revolução Industrial destacamos as macromudanças da microengenharia que propiciaram o desenvolvimento da eletrônica no interior da física, promovendo radicais implicações no processamento de dados. Fazemos referência aqui ao contexto de invenção transistor em 1947, pelos físicos John Bardeen, Walter Houser Brattain e William Bradford Shockley, na empresa Bell Laboratories, no estado americano de New Jersey (Castells, 1999).

A partir da invenção do transistor utilizando a química dos semicondutores, ${ }^{4}$ foi possível realizar o processamento de impulsos elétricos em alta velocidade e do modo binário de interrupção representado por dois níveis de tensão elétrica, ${ }^{5}$ bem como a amplificação de sinais elétricos. A invenção do transistor provoca um desdobramento fundamental na microeletrônica: a criação dos circuitos integrado ${ }^{6}$ em 1957 pelo engenheiro Jack Kilby, fato que implicou uma evolução acelerada no campo da técnica para produzir circuitos integrados em larga escala, considerando o efeito de miniaturização desses circuitos, melhor dissipação de calor por meio de seus invólucros e aumento na taxa de processamento de sinais por unidade de tempo (Castells, 1999).

4 Os elementos químicos Ge (germânio) e Si (Silício) são as bases utilizadas na indústria para produção de diodos e transistores.

5 Os estados binários 0 e 1 são representações utilizadas na eletrônica digital para o processamento de sinais elétricos com níveis de tensão de aproximadamente 0 e 5 Volts, respectivamente.

6 Conhecidos genericamente por chips, os circuitos integrados são encapsulamentos constituídos de milhões de transistores associados para dar uma finalidade ao circuito eletrônico. Como exemplos, temos circuitos integrados que funcionam como portas lógicas, amplificadores operacionais, entre outros. 
Em 1971, o engenheiro Ted Holff inventou os circuitos integrados e beneficiou a difusão da microeletrônica. Empresas como a Intel intensificaram pesquisas nas bases semicondutoras de silício para melhorar a capacidade de integração ${ }^{7}$ de circuitos em apenas um chip, a capacidade de memória ${ }^{8}$ e a velocidade ${ }^{9}$ de processamento nos circuitos (Castells, 1999).

Oliveira (2014) assevera que o avanço das técnicas empregadas na indústria microeletrônica é a base para o desenvolvimento de computadores capazes de fazer cálculos matemáticos. Anterior ao transistor, o electronic numerical integrator and computer (Eniac), criado em 1946 no Instituto de Tecnologia de Massachusetts (MIT) por John Eckert e John Mauchly, considerado o primeiro computador do mundo, consistia em um equipamento que pesava em torno de 30 toneladas, possuía aproximadamente 70 mil resistores e 18 mil válvulas a vácuo com consumo muito alto de energia elétrica (Castells, 1999).

Os projetos de computador que usavam válvula ou relés eletromecânicos eram inviáveis por causa do espaço, da necessidade de troca contínua de válvulas ou relés e do alto consumo de energia elétrica. Essa realidade gerou um contexto em que a microeletrônica provocou "uma revolução dentro da revolução" (Castells, 1999, p.79). Referimo-nos à invenção do microprocessador em 1971 e seu impacto na arquitetura de computadores da época, visto que os microprocessadores puderam incluir em um único chip a estrutura arquitetural de um computador rudimentar, provocando uma metarrevolução que gerou a noção de microcomputadores (Oliveira, 2014).

A evolução dos microcomputadores firmou-se em função do desenvolvimento de estruturas de hardware e de sistemas operacionais para o mercado dos computadores pessoais. Desde a década de 1980, as estruturas de hardware têm passado por um refinamento

7 Medida em mícrons. 1 mícron = milionésima parte de uma polegada.

8 Medida em Bytes (B).

9 Medida em Hertz $(\mathrm{Hz})$. 
contínuo para diminuir custos com matéria-prima, aumentar desempenho e reduzir as dimensões ocupadas pelo hardware (Oliveira, 2014).

Nas telecomunicações ocorreram eventos importantes para gerar o atual cenário tecnológico, sobretudo com a criação da tecnologia de comutação de pacotes. ${ }^{10} \mathrm{Na}$ década de 1990, os avanços que garantiram a comunicação de pacotes digitais via fibra ótica promoveram um aumento considerável na capacidade de linhas de transmissão de dados. Acrescente-se as transmissões de dados por radiodifusão, via satélite, via micro-ondas, por cabeamento e por banda de telefonia móvel (Castells, 1999).

O avanço no campo das telecomunicações propiciou a criação e a consolidação da internet que,

[...] nas três últimas décadas do século XX foram consequência de uma fusão singular de estratégia militar, grande cooperação científica, iniciativa tecnológica e inovação contratual. A internet teve origem no trabalho de uma das mais inovadoras instituições de pesquisa do mundo: a Agência de Projetos de Pesquisa Avançada - Arpa - do Departamento de Defesa dos Estados Unidos. [...] Quando mais tarde, a tecnologia digital permitiu o empacotamento de todos os tipos de mensagens, inclusive de som, imagens e dados, criou-se uma rede que era capaz de comunicar seus nós sem usar centros de controle. A universalidade da linguagem digital e a pura lógica de redes dos sistemas de comunicação geraram as condições para a comunicação global horizontal. (Castells, 1999, p.82)

Apenas no início da década de 1990, foi possível começar a superar as dificuldades de uso da internet e as limitações para transmissão de pacotes de dados. Uma criação tecnológica importante foi a world wide web (www) que introduziu um novo paradigma na organização dos ambientes de informação da internet por meio da

10 Resultam das tecnologias de nós ou comutação de pacotes os diversos equipamentos comutadores/multiplexadores como hubs, switches e roteadores. 
adoção de uma linguagem hipertextual para apresentação da informação em rede, tal fato é resultado de pesquisas coordenadas por Tim Berners Lee (Oliveira, 2014).

Segundo Castells (1999), a linguagem de marcação de hipertexto (HTML), o protocolo TCP/IP, o protocolo de transferência de hipertexto (HTTP), o localizador uniforme de recursos (URL), o primeiro navegador chamado de World Wide Web ou Nexus foram artefatos utilizados pelo grupo liderado por Tim Berners Lee para viabilizar o acesso às informações disponíveis na internet.

Nessa bricolagem histórica é importante destacar o fenômeno de popularização da telefonia móvel, liderada pela Nokia e pela Ericsson nos fins dos anos 1990 e que se expandiu até a atualidade. Firtman (2010) define os dispositivos móveis a partir de características específicas. Para este autor, eles devem conter a maioria das seguintes características:

- ser portátil, para ser carregado pelo usuário;

- ser pessoal, cada pessoa tem seu próprio dispositivo com customizações e normalmente não se compartilha sua utilização;

- uso all time, o usuário pode estar com o dispositivo o tempo todo;

- ser fácil de usar em diversas condições e locais;

- ser conectável, ou seja, deve ser possível conectar na internet quando necessário.

Os recortes trazidos a partir das observações de Manuel Castells (1999) e Oliveira (2014) demonstram que a expansão técnica e tecnológica ocorreu no interior de um processo histórico, cultural e social em que a informação ocupa lugar de centralidade. Os inventos tecnológicos supracitados não ocorreram de forma neutra, ao contrário, são resultantes de contextos históricos, culturais e, sobretudo, econômicos. $\mathrm{O}$ advento dos computadores pessoais e dos dispositivos móveis gera anualmente uma receita de bilhões de dólares nos países desenvolvidos e em desenvolvimento. Entretanto, não há um equacionamento no acesso a estes bens materiais e simbólicos, de modo que é possível observar processos de limitação ou exclusão digital e social relacionados aos produtos tecnológicos. 
O processo dinâmico de avanço tecnológico, informacional e de comunicação tem criado uma diversidade de ambientes de informação, sejam analógicos, digitais ou híbridos, e gerado a necessidade de reflexões teórico-práticas que favoreçam a experiência dos sujeitos quando buscam informações por meio de aparatos tecnológicos.

\section{Ambientes de informação digital e ecologias informacionais complexas}

Os ambientes de informação digital são uma macrocategoria com ampla tipologia, que engloba sites, bibliotecas digitais, repositórios institucionais, periódicos eletrônicos, museus digitais, sistemas de gestão eletrônica de documentos, entre outros. Porém, nos diversos ambientes de informação digital e também nos ambientes analógicos, nem sempre é possível encontrar a informação que se deseja ou realizar a atividade que se objetiva em função de uma inadequada organização e representação da informação, o que compromete a experiência de interação nesses produtos do engenho tecnológico (Oliveira, 2014).

Acessar e usar a informação de natureza digital, que se tornou insumo fundamental para o desenvolvimento social, político e econômico dos países, é fator relevante para o desenvolvimento humano na pós-modernidade. Referindo-se à informação digital num plano de problematização filosófica, o estudioso português Fernando Ilharco assevera que tal fenômeno surge no contexto da emergência de um novo tipo de informação gerada, gerida, manipulada, armazenada, distribuída pela tecnologia. Surge como uma nova aproximação entre o homem e o mundo, isto é, como um novo paradigma no âmbito do qual se visa descrever e entender a informação digital e tecnológica, bem como questionar os próprios fundamentos do que é, do que existe e do que somos nós, homens no mundo tecnológico (Ilharco, 2003).

Ampliando a noção de informação digital, Oliveira e Vidotti (2012, p.275) acrescentam que a informação digital é representada 
por meio da " [...] linguagem binária e armazenada em suportes digitais, independentemente das características de volatilidade do suporte, cujo acesso e uso se dão através de equipamentos computacionais (hardware e software) [...]". E ainda afirmam que a representação da informação em linguagem binária torna viável a transmissão de dados em equipamentos computacionais e de telecomunicações.

No âmbito da pós-modernidade, a informação digital tem sido organizada, representada, armazenada e disponibilizada no que, a priori, chamaremos de lugares informacionais. O termo "lugares" deriva da palavra grega loci, e é utilizado nesta argumentação em função de sua amplitude de significados e por estar em consonância com a compreensão, apresentada por Aristóteles, de que os lugares são objetos dos raciocínios dialéticos e retóricos, são assuntos comuns à ética, à política, à física e a outras disciplinas (Abbagnano, 2007), em nosso caso diz respeito à Ciência da Informação que se interessa em investigar os lugares próprios ${ }^{11}$ da informação. $\mathrm{Na}$ literatura da Ciência da Informação os lugares da informação têm sido chamados de espaços, ambientes, sistemas, repositórios, bibliotecas, arquivos, museus, entre outros (Oliveira, 2014). As autoras Camargo e Vidotti (2011) defendem que esses lugares devem ser chamados de ambientes informacionais digitais e destacam as semelhanças que tais ambientes teriam com ambientes informacionais tradicionais, embora se diferenciem destes últimos por armazenar a informação de natureza digital.

Embora autores como Camargo e Vidotti (2011), Oliveira e Vidotti (2012), Santos e Vidotti (2009) tenham utilizado em seus estudos o termo ambientes informacionais digitais fazendo referência aos diversos lugares que armazenam e facilitam o acesso às informações de natureza digital, sobretudo no contexto da internet

11 Os lugares comuns não têm objeto específico, por isso não aumentam o conhecimento das coisas; os lugares próprios, entretanto, utilizam-se especialmente de proposições oportunamente escolhidas e contribuem para o conhecimento das ciências (Abbagnano, 2007). 
e da web, Oliveira (2014) propõe um deslocamento sintático para aproximar o termo da Ciência da Informação.

Baseado nas reflexões teóricas da pesquisadora alemã Ingetraut Dahlberg (1978) sobre a teoria do conceito, Oliveira (2014) entende que a expressão "ambientes informacionais digitais" concentra o seu núcleo conceitual no termo ambientes, de modo que os termos informacionais e digitais são qualificadores e fazem alusão ao núcleo conceitual. Segundo o mesmo autor, o termo em questão remete a objetos gerais e constituem um conceito também geral, que delimita/classifica/categoriza ambientes por sua natureza/ função de comportar a informação digital, englobando todos os tipos/modelos/padrões de ambientes que se encaixam nesse arranjo (Dahlberg, 1978).

Para Oliveira (2014) a forma de dar título aos lugares pós-modernos da informação digital pode ser mais representativa para a área de Ciência da Informação se for adotado o termo "ambientes de informação digital”. O autor supracitado afirma que os termos "ambientes informacionais digitais" e "ambientes de informação digital" possuem diferenças conceituais e semânticas. O primeiro tem apenas o termo "ambientes" como núcleo conceitual; o segundo tem dois elementos que se constituem núcleos conceituais, "ambientes e informação". Trata-se de uma diferença que tem implicações semânticas. No primeiro termo existe uma relação hierárquica entre os elementos constituintes que direciona atenção para o termo ambientes; já a segunda acepção divide as atenções com mais equidade para os fragmentos ambientes e informação, tornando o termo digital um qualificador da informação e pode qualificar também o ambiente como digital. Ainda, o pesquisador demonstra interesse nos estudos sobre os lugares que contêm informação digital, na tentativa de melhor alinhar os estudos arquiteturais que tratam dos ambientes de informação digital à Ciência da Informação. Para tanto sugere um tratamento equânime aos elementos "ambiente" e "informação" no conceito: ambientes de informação digital.

Adotamos o termo "ambientes de informação digital", como uma alternativa conceitual para os lugares de informação de natu- 
reza digital. Ademais, independentemente da análise conceitual e do conceito adotado, os ambientes de informação digital são uma realidade que penetrou em todos os setores da sociedade, todos os campos do conhecimento e no cotidiano das pessoas, fazendo parte inclusive do que Oliveira (2014) chama de Ecologia Informacional Complexa.

De forma recorrente, o termo ecologia aparece em estudos na área de Ciência da Informação e também nos estudos iniciais sobre Arquitetura da Informação Pervasiva. Em parceria com Larry Prusak, Thomas Davenport discute os processos de gestão da informação considerando as ecologias informacionais como uma forma de qualificar a conjuntura informacional e tecnológica dos anos 1990.

Quando começamos a pensar nas muitas relações entrecruzadas de pessoas, processos, estruturas de apoio e outros elementos do ambiente informacional de uma empresa, obtemos um padrão melhor para administrar a complexidade e a variedade do uso atual da informação. Também poderíamos descrever a ecologia da informação como administração holística da informação ou administração informacional centrada no ser humano. O ponto essencial é que essa abordagem devolve o homem ao centro do mundo da informação [...] (Davenport, 1998, p.21, grifo do autor).

Sobre a citação acima, Oliveira (2014) comenta que, embora Davenport estivesse envolto aos problemas organizacionais e de gestão da informação da década de 1990, seu pensamento acerca da ecologia informacional tem fundamentos que podem ser aplicados na contextura da Arquitetura da Informação Pervasiva. Ainda assevera que sua visão sobre ecologia era uma metáfora usada para dar respostas holísticas a problemas já marcadas pela complexidade. Para Davenport (1998) a ecologia da informação, além de exigir um modo holístico de pensar, tem quatro atributos-chave:

- integração dos diversos tipos de informação em espaços, em ambientes, com sujeitos e com tecnologias;

- reconhecimento de mudanças evolutivas; 
- ênfase na observação e na descrição de elementos essenciais e indispensáveis ao funcionamento ecológico;

- ênfase no comportamento pessoal e informacional.

A Arquitetura da Informação concentra, nos dias atuais, esforços para tratar objetos e fenômenos com uma estrutura informacional ecológica, sistêmica e complexa. A estrutura informacional ecológica diz respeito ao conjunto de espaços, ambientes, canais, mídias, tecnologias e sujeitos com seus comportamentos, todos interligados e conectados de maneira holística pela informação. A ecologia é organizada de forma sistêmica, é um todo articulado por suas partes. Considerando a heterogeneidade das partes e que os sujeitos atuam em/sobre cada parte, as relações intra e extraecológicas são complexas no sentido moriniano do termo, ou seja, a ecologia é uma estrutura sistêmica complexa (Oliveira, 2014).

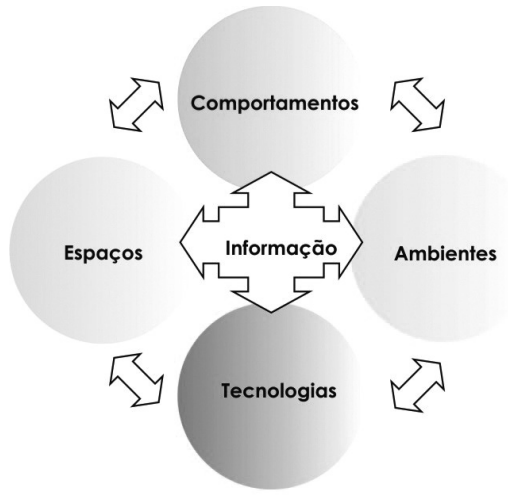

Figura 1 - Estrutura básica das Ecologias Informacionais Complexas. Fonte: Oliveira (2014).

Assim, os ambientes informacionais digitais são componentes das ecologias informacionais complexas, compreendidas como um conjunto de espaços e ambientes (analógicos, digitais ou híbridos), tecnologias e sujeitos, todos interligados e conectados de maneira holística por meio da informação. 


\section{Ciência da informação}

O que aumenta significativamente a relevância da Ciência da Informação nos dias atuais é a centralidade que a informação ocupa em todos os campos da sociedade. A Ciência da Informação é um campo que se conecta historicamente com diversos eventos. Ao investigar marcações históricas para a CI, Freire (2006) aponta a contribuição da utopia planetária de Otlet e La Fountaine como vestígios originários da Ciência da Informação, principalmente pela contribuição de Otlet que expande o conceito de documento para uma gama de produtos informacionais que surgem com a revolução industrial (Oliveira, 2014).

Sobre o marco oficial da denominação Ciência da Informação, Freire (2006) argumenta que data do início da década de 1960, a partir de eventos promovidos pelo Georgia Institute of Technology, nos Estados Unidos, do qual também participaram cientistas, escritores e filósofos estrangeiros. Como consequência natural do crescimento da produção científica e que redundara na multiplicação dos periódicos científicos, os eventos discutiram a criação de tecnologias informacionais.

Borko (1968) percebe a Ciência da Informação como uma disciplina. Para esse autor, cuja visão se tornou clássica na área, a CI tem a função de fornecer um corpo para a informação que melhorará instituições no que diz respeito aos procedimentos dedicados à acumulação e à transmissão do conhecimento (Borko, 1968).

O olhar de Saracevic (1996) sobre a Ciência da Informação traz contribuições para que ela seja compreendida como um campo científico com as seguintes características fundamentais: a interdisciplinaridade, a ligação inexorável com as tecnologias e a participação ativa e deliberada na sociedade da informação. Oliveira (2014) defende que a partir da tríplice caracterização proposta por Saracevic (1996) podemos ligar a Ciência da Informação à Arquitetura da Informação, estabelecer um link entre a Ciência da Informação e as tecnologias pervasivas, e reinterpretar a sociedade da informação, apresentando-a como sociedade pós-moderna. 
Para Leis (2005), a característica interdisciplinar é uma condição fundamental do ensino e da pesquisa na sociedade contemporânea e pode ser definida como um ponto de cruzamento entre atividades com lógicas diferentes, com o objetivo de minimizar análises fragmentadas e as sínteses simplificadoras.

A Ciência da Informação é per se um campo interdisciplinar, que questiona a (hiper) especialização da modernidade. Na Ciência da Informação há um diálogo constante com diversas áreas do conhecimento, como biblioteconomia, arquivologia, computação, comunicação, administração, psicologia e linguística. Esse diálogo não a enfraquece enquanto ciência e disciplina, mas permite ampliar seus horizontes científicos para mais bem investigar seu objeto: a informação (Oliveira, 2014).

Borko (1968) também reconhece o caráter interdisciplinar da CI. Para ele, trata-se de uma ciência interdisciplinar que investiga as propriedades e o comportamento da informação, as forças que a governam, o fluxo e o uso da informação, e suas técnicas, tanto manuais como mecânicas, para processar informação de fácil armazenamento, recuperação e disseminação.

Existem objetos de investigação que "[...] revelam-se tão complexos que só podem ser tratados e solucionados por uma abordagem multi, inter ou transdisciplinar [...]" (Japiassu, 2006, p.26). A nosso ver, é o caso da CI, que se expande numa perspectiva inter/ transdisciplinar.

A transdisciplinaridade ocorre porque a racionalidade científica é incapaz de desvelar inúmeras facetas da realidade, e é necessário validar outras formas de conhecer (diversidade epistemológica) e correlacionar conhecimentos (pluralidade epistemológica) segundo uma nova racionalidade capaz de apreender a complexa realidade (Calegare; Silva Junior, 2012).

A compreensão de Calegare e Silva Junior (2012) está alinhada ao pensamento de Hilton Japiassu sobre transdisciplinaridade e ao pensamento de Edgar Morin sobre complexidade. Além disso, coaduna com as práticas de investigação na Ciência da Informação, que busca compreender a geração, construção, disseminação, ges- 
tão, armazenamento, recuperação, arquitetura, encontrabilidade, usabilidade e acessibilidade da informação. A CI trata a informação numa perspectiva multifacetada e poliepistemológica que exige a inter/transdisciplinaridade como estratégia para compreensão da realidade informacional.

Sobre a característica relacional da Ciência da Informação com a tecnologia e seu papel na sociedade da informação, Saracevic (1996) argumenta que o imperativo tecnológico determina a CI, como ocorre também em outros campos e impõe a transformação da sociedade moderna em sociedade da informação, era da informação ou sociedade pós-industrial.

$\mathrm{Na}$ Ciência da Informação, o debate sobre a epistemologia, as teorias e as metodologias próprias da CI são alvo de dissenso. Nesse ponto, concordamos com Lena Vânia Pinheiro (2005), que resolve essa questão remetendo a CI para fora do círculo das ciências modernas e positivistas. Complementamos o pensamento da autora inscrevendo a CI no âmbito do paradigma da pós-modernidade. Pinheiro (2005, p.38-39) ressalta:

Como ciência social que é, a Ciência da Informação apresenta singularidades próprias de seu objeto de estudo, por si só, de acentuado grau de abstração e complexidade e pela subjetividade que perpassa o ciclo de transferência da informação, aí compreendida a geração de conhecimento, a sua subsequente representação em informação, por sua vez organizada, processada, recuperada, disseminada, disponível na Internet e utilizada, num ininterrupto processo - moto contínuo. As críticas que lhe são feitas como disciplina científica, de fragilidade conceitual e teórica aos resultados de aplicações de leis, parecem responder a exigências naturalistas e positivistas anacrônicas e inadequadas à natureza da Ciência da Informação. Os muitos e relevantes estudos teóricos analisados neste trabalho refutam a fragilidade conceitual assinalada por diversos autores. Pelo contrário, há um sério e fértil empreendimento teórico, e clara evolução de conceitos, princípios, hipóteses e métodos. 
A crítica de Pinheiro (2005) nos ajuda a perceber que as exigências de adequação ao paradigma moderno para recebimento do status de ciência moderna não são concretizáveis no campo da CI. Tal realidade não a torna uma ciência menor ou uma não ciência, mas nos faz vê-la como ciência pós-moderna. Dentro da CI, o diálogo inter/transdisciplinar com teorias e metodologias de outras disciplinas não a fragiliza, mas potencializa a superação dos modelos científicos lineares, hiperespecializados e tradicionalistas.

Gonzalez de Gomez (2000) ressalta o caráter poliepistemológico na CI. A autora argumenta que a metodologia da Ciência da Informação deve dar conta desse aspecto poliepistemológico e fluido do termo "informação" como fenômeno, processo ou construção que se vincula aos diversos extratos de realização. Essa característica da Ciência da Informação também pode ser percebida na contribuição de Capurro (2003) que defende na Ciência da Informação a existência de três paradigmas distintos que não se excluem, nem se extinguem no processo histórico da Ciência da Informação, mas aparecem com mais ou menos força em determinados momentos históricos e dependendo do enfoque dado aos problemas informacionais. Esses diferentes paradigmas estão fundamentados em posturas teóricas e metodológicas também distintas e constituem-se epistemologicamente de forma plural.

Capurro (2003) defende a tese de que a Ciência da Informação nasce em meados do século XX com um paradigma físico, questionado por um enfoque cognitivo idealista e individualista, sendo este por sua vez substituído por um paradigma pragmático e social.

Para Capurro (2003), a Ciência da Informação inicia-se com uma teoria de Recuperação de Informação fundamentada numa epistemologia fisicista. No tocante à informação, esse paradigma acredita que há um objeto físico que o emissor transmite ao receptor. Esse paradigma é tomado como modelo em Ciência da Informação, o que resulta na analogia entre a veiculação física de um sinal e a transmissão de uma mensagem. A crítica mais contundente a esse paradigma é a exclusão do papel ativo do sujeito cognoscente no processo de recuperação da informação. O paradigma físi- 
co parece ser o que melhor adequaria a Ciência da Informação aos pressupostos da modernidade, mas esse paradigma não possibilita que os problemas informacionais científicos sejam adequadamente abordados por meio de análises qualitativas ou mistas, sobretudo quando a ação dos sujeitos é um elemento fundamental para a compreensão dos problemas informacionais (Oliveira, 2014).

Em certa contraposição ao paradigma físico aparece o paradigma cognitivo. A priori a Ciência da Informação tem relação com os suportes físicos da informação, mas, na realidade, seu fim é recuperação da própria informação, o que influencia diretamente o paradigma cognitivo proposto por Brookes (1980), que dialoga com a teoria dos três mundos de Popper. Brookes (1980) elege o terceiro mundo de Popper como um mundo de "objetos inteligíveis", ou também "conhecimento sem sujeito cognoscente", o mundo dos cientistas da informação. Nesse contexto, há de se destacar a contribuição de Farradane ao mostrar que grande parte da área da Ciência da Informação é cognitiva, isto é, "[...] trata com processos de pensamento, uma das mais difíceis áreas de investigação" (Farradane, 1980, p.75).

Ainda dentro do debate em relação aos paradigmas da Ciência da Informação, é preciso destacar o paradigma social, que surge com uma postura crítica e evidencia os limites do paradigma cognitivo. Para os cognitivistas da informação, a informação é entendida como algo separado do usuário e depositada num mundo numênico, o terceiro mundo de Popper. Frohmann (1995), baseando-se em Wittgeinstein e Foucault, critica o paradigma cognitivo como idealista e associal. No paradigma social, o avanço fundamental ocorre em relação ao objeto de investigação da CI, que é ampliado para o estudo das relações entre os discursos, as áreas do conhecimento e os documentos em relação ao acesso de distintas comunidades de sujeitos.

Questionando os paradigmas da Ciência da Informação, propostos por Capurro, Silva e Ribeiro (2006) acreditam que a Ciência da Informação atravessa um momento de enfraquecimento de um paradigma custodial, caracterizado pelo patrimonialismo, histori- 
cismo e tecnicismo e que cede lugar a um paradigma pós-custodial, de cunho informacional e científico.

Para Malheiro e Ribeiro (2011), a informação no paradigma pós-custodial é um fenômeno humano e social que se dissemina por meio dos processos de criação-seleção natural. Os autores defendem ainda que:

- a custódia e preservação devem estar vinculadas ao acesso público da informação;

- a materialização em qualquer suporte é um epifenômeno;

- o incessante e natural dinamismo informacional se opõe ao "imobilismo" documental;

- o imperativo de indagar, compreender e explicitar (conhecer) a informação social, por meio de modelos teórico-científicos cada vez mais exigentes e eficazes.

Tratando de aspectos teórico-funcionais, os autores supracitados defendem a informação social como objeto que deve ser investigado em sintonia com as ciências sociais, para compreender o social e o cultural nos processos informacionais de gestão de qualquer entidade ou organização.

Vechiato (2013) assevera que as características dos paradigmas custodial e pós-custodial estão suficientemente amadurecidas e vêm sendo defendidas há mais de uma década em Portugal na tentativa de demonstrar a importância de um ponto de vista alternativo para as ações teóricas e para a práxis da Ciência da Informação. Tal amadurecimento fez com que Silva (2006) produzisse uma definição de informação compreendida como fenômeno, considerando a complexidade que abordamos neste livro e tomando-a como fenômeno humano e social.

No âmbito da Ciência da Informação [a informação] [...] tem uma dupla funcionalidade semântica. Refere um fenómeno humano e social que compreende tanto o dar forma a ideias e a emoções (informar), como a troca, a efectiva interacção dessas ideias e emoções entre seres humanos (comunicar). E identifica um objecto científico, a saber: conjunto estruturado de representações mentais 
e emocionais codificadas (signos e símbolos) e modeladas com/ pela interacção social, passíveis de serem registadas num qualquer suporte material (papel, filme, banda magnética, disco compacto etc.) e, portanto, comunicadas de forma assíncrona e multidireccionada. (Silva, 2006, p.150)

No conceito apresentado, a informação é compreendida com dupla funcionalidade semântica - as facetas humana e social que Silva (2006) apresenta estão alinhadas à compreensão de informação que foi apropriada pela Arquitetura da Informação ao longo de sua história. A preocupação dos arquitetos da informação com a tríade conteúdo, contexto e comportamento do usuário subjaz o entendimento de que a informação é um fenômeno social, por isso os conteúdos devem ser contextualizados e deve ser dada atenção aos comportamentos dos sujeitos. A informação é de fato um fenômeno humano e social, que exige um olhar poliepistemológico, norteado pela compreensão da complexidade e que suscita a produção de conhecimentos multifacetados, o que contribui para uma Ciência da Informação pós-moderna, poliepistemológica, dinâmica, flexível com preocupações voltadas aos fenômenos informacionais que por natureza são complexos. 


\section{2 \\ ARQuitetura da INFORMAÇÃo}

Os objetos de pesquisa de um campo científico ou disciplinar podem ser lidos, visualizados, interpretados, conhecidos ou investigados a partir de enfoques etimológicos, epistemológicos, cronológicos, sociológicos, filosóficos, empíricos, entre outros. Abordando a cientificidade da Arquitetura da Informação, recorremos às ideias de Macedo (2005, p.143) em relação ao enquadramento da Arquitetura da Informação no âmbito da ciência. Sobre esse tema a autora assevera que a Arquitetura da Informação tem características de uma disciplina que se estabeleceu no contexto da ciência pós-moderna. A ciência moderna implicava a necessidade de existência de uniformidades básicas e regularidades empíricas acerca do fenômeno que engloba o objeto de estudo de uma área, assim como a utilização de um método científico rigoroso, geralmente quantitativista, para investigá-lo. Na pós-modernidade, tais pressupostos têm sido repensados.

Os valores de universalidade e certeza têm dado lugar à pluralidade e à complexidade. Nessa conjuntura, a Arquitetura da Informação se estabelece com uma natureza inter/transdisciplinar, com seus métodos, modelos e teorias derivados do diálogo com outras disciplinas. 
O que Macedo (2005) expôs sobre a interdisciplinaridade, sobre a complexidade e sobre o diálogo com métodos e teorias de outras disciplinas se alinha ao discurso que escrevemos neste livro sobre a Ciência da Informação, visto que os atuais problemas informacionais e tecnológicos são complexos e exigem o diálogo inter/transdisciplinar.

Nessa linha de entendimento, Albuquerque (2010, p.133) discute a fundamentação e caraterização da AI como disciplina e a concebe como um programa de investigação epistemológica da realidade que busca identificar e relacionar, no mínimo e necessariamente, quatro dimensões no problema tratado: forma, contexto, manifestação e significado. Para o autor supracitado, a AI pode adotar duas abordagens: uma orientada para o objeto, quando o propósito é analisar o fenômeno; outra orientada ao produto, quando o propósito é criar um produto para atuar sobre o fenômeno.

Vemos nesse conceito um esforço para situar a Arquitetura da Informação no campo das Ciências e assim delimitar as formas de abordagem da AI diante dos objetos de investigação. Numa reflexão epistêmica sobre a Arquitetura da Informação, Albuquerque e Lima-Marques (2011, p.68) afirmam:

Como disciplina, o termo Arquitetura da Informação refere-se a um esforço sistemático de identificação de padrões e criação de metodologias para a definição de espaços de informação, cujo propósito é a representação e manipulação de informações; bem como a criação de relacionamentos entre entidades linguísticas para a definição desses espaços de informação.

Concordamos com as visões de Macedo (2005), Albuquerque (2010) e Albuquerque e Lima-Marques (2011) sobre a Arquitetura da Informação e acrescentamos a percepção de que existem abordagens regulares na AI. Para tanto, baseamo-nos em León (2008) e Resmini e Rosati (2011). A ação dialógica feita com os autores supracitados é adequada, pois a interdisciplinaridade evidenciada na AI, bem como a presença de diferentes abordagens que a orien- 
taram desde seu início até os dias atuais, avigoram suas características de disciplina científica pós-moderna, com uma constituição epistemológica fluida, versátil e adaptável, permitindo que a AI ofereça respostas mais eficientes aos complexos e mutáveis problemas sociotécnicos da pós-modernidade.

A Arquitetura da Informação tem se apresentado como uma práxis profissional e como um campo de estudos com foco na solução de problemas relacionados ao acesso e uso do vasto quantitativo de informações disponíveis (Resmini; Rosati, 2011). Todavia, a Arquitetura da Informação não se cristalizou em uma perspectiva única, não se fundamentou na influência de apenas um ramo disciplinar e epistemológico (Oliveira, 2014). Nesse sentido, León (2008) e Resmini e Rosati (2011) discutem o transcurso da AI por meio de enfoques ou visões que a influenciaram, destacando a importância da arquitetura, do design de informação, dos sistemas de informação, da Ciência da Informação e, mais recentemente, da computação ubíqua e do design de serviços, como vetores que influenciaram a Arquitetura da Informação ao longo do tempo.

As visões de León (2008) e Resmini e Rosati (2011) evidenciam características pós-modernas na Arquitetura da Informação. León (2008) faz uma revisão crítico-histórica sobre a AI que é complementada pelos estudos de Resmini e Rosati (2011) ao abordarem a mais recente perspectiva da AI, abrangendo qualidades do que é pervasivo e ubíquo. Os autores mencionados têm lastro discursivo na Ciência da Informação e seus subsídios nos permitem ampliar as possibilidades de aplicação da AI em vários cenários da sociedade pós-moderna.

\section{Articulando histórias e conceitos}

Dialogando com Negroponte (2008), Pake (1985), Hearst (2009), Wurman (1996), entre outros autores, León (2008) faz uma revisão histórica e crítica sobre o uso do termo arquitetura nos contextos tec- 
nológicos, indicando que o termo começa a ser usado em contextos computacionais, mais especificamente pela empresa IBM por volta de 1959. Vestígios do uso do termo são encontrados em 1962 no livro Planning a Computer System: Project Stretch, editado por Werner Buchholz. Nessa obra, discute-se a arquitetura de computadores como arte de determinar as necessidades dos usuários em conjunturas organizacionais. Ainda na literatura técnica da IBM, vemos o termo arquitetura ser usado em 1964 numa analogia a estrutura conceitual e ao comportamento funcional, diferenciando-se da organização e do fluxo dos dados, do design lógico e da implementação física (Amdahl; Blaauw; Brooks, 1964). Ainda no mapeamento dos vestígios do termo arquitetura em assuntos tecnológicos, ressaltamos o seu uso, em 1967, pelo Grupo de Arquitetura de Máquinas do MIT fundado por Nicholas Negroponte (León, 2008).

Sobre o aparecimento do termo Arquitetura da Informação, Pake (1995) citado por León (2008) e por Resmini e Rosati (2011) discorre sobre a criação, em Julho de 1970, da Xerox Palo Alto Research Center (PARC) e de um grupo de cientistas especializados em ciências naturais e Ciência da Informação que receberam a incumbência de criar uma Arquitetura da Informação aplicável aos artefatos tecnológicos criados pela Xerox. Segundo Resmini e Rosati (2011) esse grupo foi responsável por um número significativo de contribuições no campo que chamamos hoje de Interação Humano-Computador (IHC).

A segunda evidência histórica do termo Arquitetura da Informação, segundo León (2008), se encontra nos trabalhos de Richard Saul Wurman, entre os quais está um artigo, escrito com Joel Katz e intitulado "Beyond Graphics: The Architecture of Information", em outubro de 1975. Esse texto foi publicado pelo AIA Journal, numa conferência ocorrida em 1976, durante o evento do American Institute of Architecture (AIA), que naquele ano tinha como tema The Architecture of Information. ${ }^{1}$

1 León (2008) ressalta que o termo Arquitetura da Informação é usado de duas formas: architecture of information e information architecture. Embora tenham 
A terceira evidência do uso do termo "arquitetura de informação", utilizando a terminologia information architecture é encontrada em um conjunto de artigos publicados na década de $1980{ }^{2}$ A noção de AI usada pelos autores desses artigos diz respeito à Arquitetura da Informação como artefato para o design e construção de sistemas de informação, ${ }^{3}$ abordando-a numa perspectiva de aplicação prática (León, 2008).

Antes da publicação da obra de Rosenfeld e Morville (1998), a tese de doutorado de Weitzman (1995) foi publicada pelo MIT abordando a Arquitetura da Informação com o seguinte título: The architecture of information: interpretation and presentation of information in dynamic environments (León, 2008). Nessa tese, Weitzman (1995) inclui a Xerox no rol das primeiras corporações a abordar a noção de estrutura de informação e usar o termo Arquitetura da Informação como campo propulsor para os negócios corporativos (Resmini; Rosati, 2011).

Desenhando um traçado cronológico para a AI, León (2008) destaca que entre 1996 e 1998 autores como Wurman (1996), Cook (1996), Kahn e Lenk (1998), Nielsen (1998) e Rosenfeld e Morville (1998) publicaram livros com contribuições importantes para substanciar a AI. Entre os quais destacamos a contribuição de Rosenfeld e Morville (1998), bibliotecários e cientistas da informação que, por meio da obra Information Architecture for the World Wide Web, construíram possibilidades de aplicação da AI em contextos web utilizando o arcabouço de conhecimentos acumulados pela biblioteconomia e Ciência da Informação.

ligeiras diferenças sintáticas, ambas as formas significam a mesma coisa, sendo que a primeira é usada em contextos mais formais, e a segunda é uma forma mais coloquial.

2 Os artigos aos quais nos referimos podem ser encontrados na base de dados Lisa: Wetherbe e Davis (1983); Vogel e Wetherbe (1984); Dickson e Wetherbe (1985); Brancheau e Wetherbe (1986); Wetherbe (1987); Brancheau, Stucher e March (1989); Vogel e Wetherbe (1991).

3 Information system design. 
Mapeando publicações sobre a AI nos anos 2000, Tramullas (2003) assevera que outros artigos e livros sobre AI foram escritos e, entre eles, destacam-se os autores Jesse James Garret, Susan Batley, Christina Wodtke, Earl Morrogh, Peter van Dijk, Louis Rosenfeld e Peter Morville e outros.

As aproximações históricas feitas até aqui podem ser sintetizadas na cronologia feita por León (2008), considerando o intervalo entre os anos 1970 e os dias atuais.

Wetherbe, Vogel, Davis. Dickson,

Brancheou, Zackman

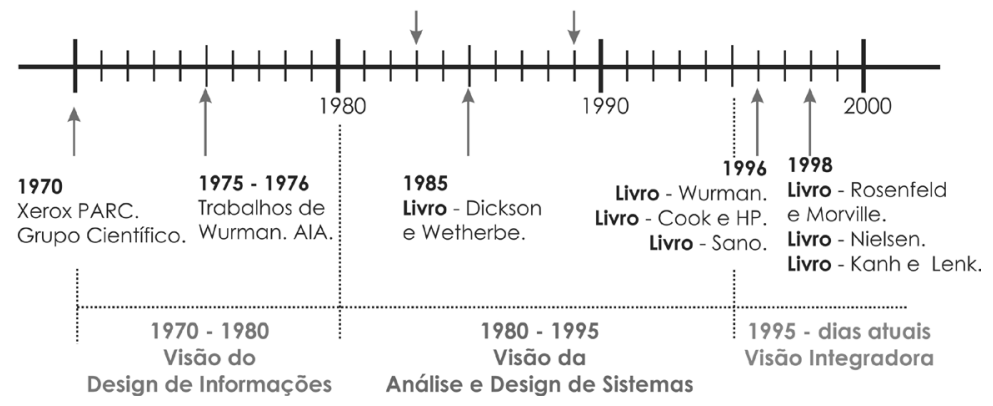

Figura 2 - Cronologia da AI entre os anos 1970 e 1998 segundo León Fonte: Adaptada de León (2008).

A timeline de León (2008) nos permite visualizar três visões que influenciam a AI ao longo de sua história, referimo-nos ao que León chama de visão do design de informação (de 1970 a 1980), visão da análise e design de sistemas (1980 a 1995) e visão integradora (a partir de 1995). O que este autor chama de visões, nós chamamos de abordagens que potencialmente influenciaram os estudos e as práticas da AI ao longo dos anos. Ainda sobre a timeline, percebemos um traçado relativamente rígido e que separa as visões ou abordagens da AI. Defendemos a ideia de que essas visões ou abordagens podem, sobretudo nos momentos de transição, se mesclar, se interconectar e até se sobrepor. Defendemos ainda que nenhuma abordagem é revogada ou totalmente extinta, embora, dependendo da força com a qual uma nova abordagem se impõe, a 
abordagem anterior se enfraqueça e seja invisibilizada no processo histórico (Oliveira, 2014).

Os estudiosos Resmini e Rosati (2011) fazem uma releitura da timeline de León (2008) conforme apresentamos na Figura 3.

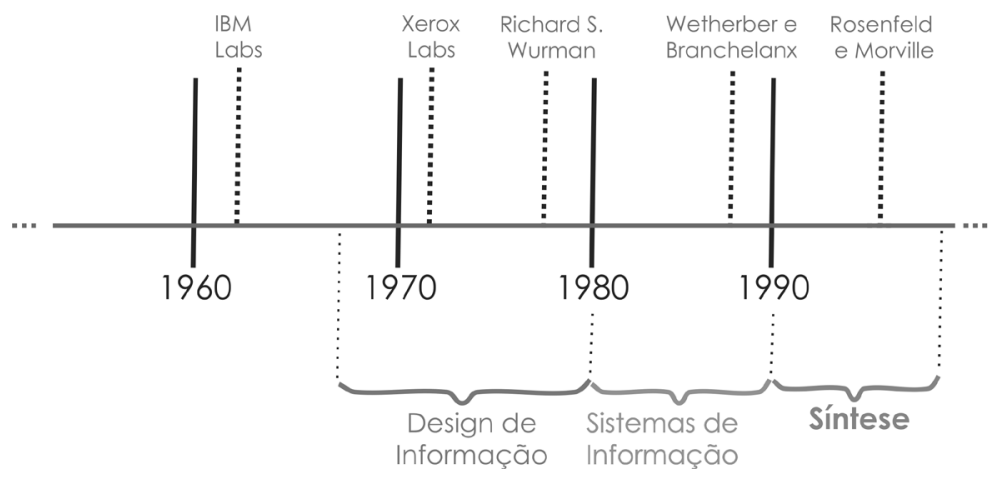

Figura 3 - Cronologia para Arquitetura da Informação até os anos 2000.

Fonte: Adaptada de Resmini e Rosati (2011).

Oliveira (2014) compara as Figuras 2 e 3, percebe que Resmini e Rosati (2011) concordam com León (2008) em relação ao momento em que a visão do design de informação cede lugar aos sistemas de informação como norteador dos estudos e práticas em AI. Ainda comparando as timelines, Oliveira (2014) afirma que os autores divergem ligeiramente quanto à transição dos sistemas de informação para uma visão sintético-integradora, com marcação em 1990 para León (2008) e 1995 para Resmini e Rosati (2011). Embora percebamos suaves divergências entre as timelines, há concordância quanto às abordagens.

Resmini e Rosati (2011) trazem um acréscimo ao traçado histórico e cronológico da AI, conforme evidenciamos na Figura 4. O período denominado síntese na Figura 3 recebe novos rótulos na Figura 4, de modo que a visão integradora é particionada em duas visões: AI clássica e AI pervasiva e ubíqua. 


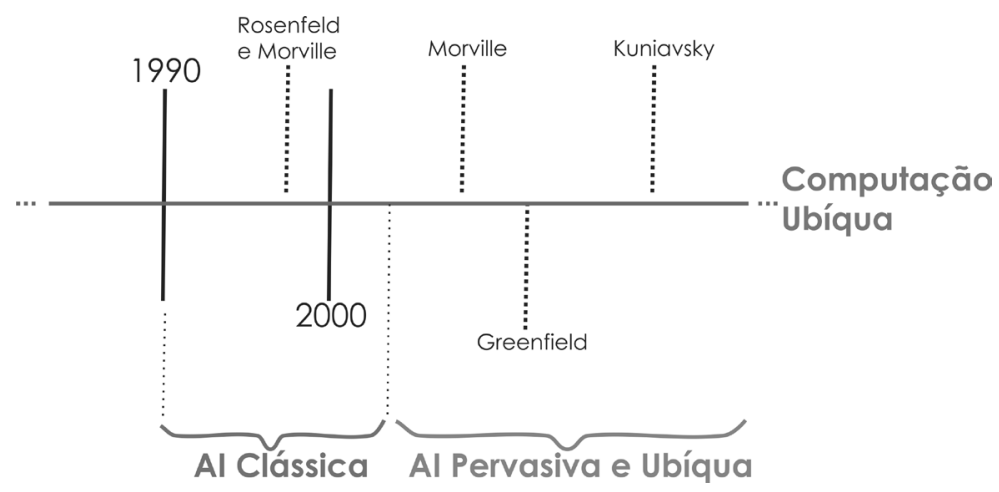

Figura 4 - Cronologia com Arquitetura da Informação Pervasiva.

Fonte: Adaptado de Resmini e Rosati (2011).

Resmini e Rosati (2011) rotulam como "clássicos" os estudos e as práticas de AI ocorridos entre os anos 1990 e 2000. Apresentam os vestígios de um processo de modificação teórica e prática da AI num movimento de resposta aos novos problemas informacionais que transcendem os limites e os contextos web, esses autores chamam esse movimento de AI pervasiva e Ubíqua (Oliveira, 2014).

Compreendemos que os processos de construção, manutenção e ruptura dessas abordagens são compartilhados pelos sujeitos que atuam na Arquitetura da Informação. São ainda uma espécie de norteador das atividades científicas. As análises feitas por León (2008) e Resmini e Rosati (2011) delineiam uma história para a AI, contada considerando a influência de campos disciplinares como arquitetura, design, Ciência da Informação, sistemas de informação, computação ubíqua e design de serviços, campos que se vinculam à $\mathrm{AI}$ em seu transcurso, constituindo as abordagens que apresentamos na Figura 5. Contudo, a inter/transdisciplinaridade possibilitou diálogos da AI com campos como a ergonomia, a usabilidade, a psicologia organizacional, a ciência da computação, as ciências cognitivas, o desenho industrial, o design gráfico, a sociologia, a antropologia, entre outras (Macedo, 2005; Dillon, 2003).

Reconhecemos que a atuação inter/transdisciplinar da AI quebra as fronteiras disciplinares e traz à AI uma fluidez identitária. No entanto, alguns desses campos atuam sobre a $\mathrm{AI}$ ao ponto de 
vermos, de forma evidente e recorrente, seus elementos conceituais presentes nos principais conceitos da Arquitetura da Informação. São esses campos e seus núcleos conceituais, presentes de forma manifesta e recursiva na AI, que geram o que chamamos de abordagens da AI, conforme mapa conceitual desenvolvido por Oliveira (2014) e apresentado na Figura 5.

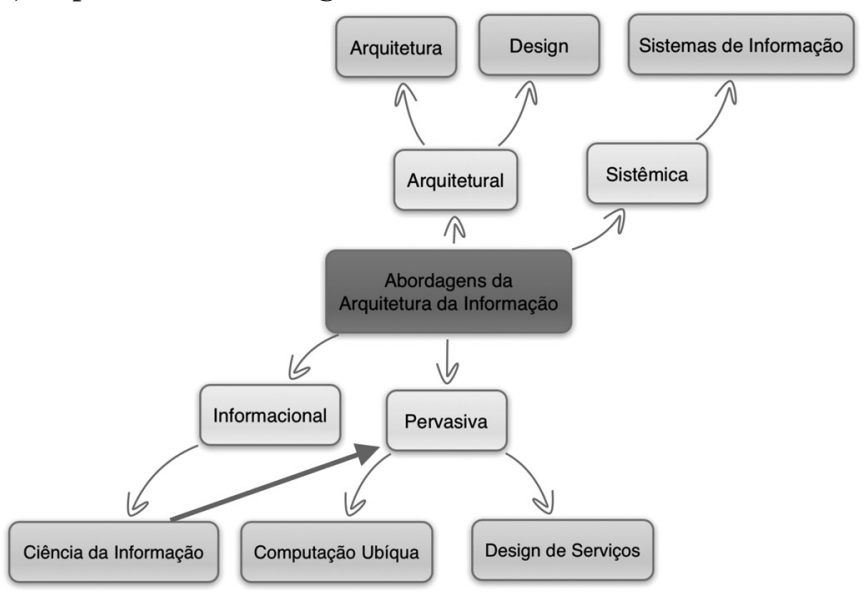

Figura 5 - Mapa Conceitual das Abordagens da Arquitetura da Informação. Fonte: Oliveira (2014).

Nossa compreensão acerca das abordagens da AI é representada pelas ideias de Oliveira (2014), que por sua vez dialoga com as obras de León (2008) e Resmini e Rosati (2011). Na realidade, Oliveira (2014) realiza uma releitura das contribuições de León (2008) e Resmini e Rosati (2011), transformando o que eles chamam de visão em abordagem e estruturando cada abordagem a partir de disciplinas externas à $\mathrm{AI}$, mas que a ela se amalgamam ao ponto de orientar seus estudos e práticas. Trata-se das abordagens arquitetural, sistêmica, informacional e pervasiva.

De agora em diante, apresentaremos as abordagens da AI articuladas por Oliveira (2014), considerando suas estruturas, a noção de informação que pode estar subjacente, os autores que se destacaram e suas contribuições para a AI. Vale destacar de antemão que a linha vermelha e pontilhada da Figura 5 sinaliza nossa compreen- 
são de que a Ciência da Informação tem um papel fundamental na abordagem pervasiva, pois, conforme defende Oliveira (2014), a pervasividade é um atributo da informação, como veremos adiante.

\section{Abordagem arquitetural}

Oliveira (2014) denomina abordagem arquitetural a primeira vertente que influencia com vigor a Arquitetura da Informação, sobretudo no contexto de seu nascimento e expansão. Tal abordagem gera uma Arquitetura da Informação com fundações interdisciplinares na arquitetura e no design.

A arquitetura é um campo devotado à racionalização dos espaços em função do uso que a sociedade ou os sujeitos lhe atribuem. Duarte (1999) sinaliza que a arquitetura, mais que para proteger os sujeitos das intempéries, é uma forma de organização de referências da cultura dos sujeitos e de seu posicionamento crítico junto ao ambiente natural, "[...] é um meio de transmissão de informações com o qual o homem vem dando sua medida aos territórios que ocupa [...]" (Duarte, 1999, p.13). De forma complementar, Artigas (1981, p.71) assevera que a arquitetura é antes de tudo uma "[...] expressão da cultura de um povo, que se serve do avanço técnico e da produção industrial, sobre os quais exerce também sua influência criadora [...]" e artística.

Com uma práxis projetiva que racionaliza o espaço, o território, o tempo, o belo, o bem-estar e as necessidades dos sujeitos, o campo arquitetônico "[...] situa-se numa área intermediária entre ciência e arte, tendo que responder questões não perfeitamente definidas e permitindo múltiplas abordagens [...]" (Kowaltowski et al., 2008, p.8). Numa perspectiva similar, Burden (2006, p.42) compreende a arquitetura como "[...] a arte e a ciência de projetar e construir edificações ou grupos de edificações de acordo com critérios estéticos e funcionais $[\ldots]$ ".

Discorrendo sobre a arquitetura e as tecnologias de informação e comunicação, Nardelli (2007) afirma que a arquitetura tradicional 
era a materialização de desenhos realizados sobre o papel, já a arquitetura contemporânea é a materialização das técnicas digitais que permitem a concepção de objetos com alto nível de complexidade.

A compreensão de Nardelli (2007) denota a adaptabilidade da arquitetura diante dos desafios da pós-modernidade, profundamente marcada pelas TIC. Além da arquitetura, o campo do design serviu de coluna para sustentação da abordagem arquitetural. Essa afirmação é corroborada por Camargo e Vidotti (2012, p.6), que consideram "[...] o design uma área base para compreensão da AI [...]".

Fazendo um apanhado etimológico sobre o termo design, Villas-Boas (2000, p.48) assevera que design é uma palavra inglesa originária do termo latino designo, que significa designar, indicar, representar, marcar, ordenar. Para o referido autor, o termo design faz uma maior aproximação com a noção de configuração palpável, de projeto.

Ampliando a análise conceitual do campo do design, Niemayer (2007, p.24) informa que o

[...] design tem sido entendido segundo três tipos distintos de prática e conhecimento. No primeiro, o design é visto como atividade artística, em que é valorizado no profissional o seu compromisso como artífice, com a estética, com a concepção formal, com a fruição do uso. No segundo entende-se o design como um invento, como um planejamento, em que o designer tem o compromisso prioritário com a produtividade do processo de fabricação e com a atualização tecnológica. Finalmente, no terceiro aparece o design como coordenação, onde o designer tem a função de integrar os aportes de diferentes especialistas, desde a especialização de matéria-prima, passando pela produção à utilização e ao destino final do produto. Neste caso, a interdisciplinaridade é a tônica. (Niemayer, 2007, p.24)

No paradigma arquitetural, o campo do design influencia os estudos e as práticas da Arquitetura da Informação por meio do design de informação, do design de interação, do design gráfico, entre outros. 
Refletindo sobre a interdisciplinaridade na AI, Caldas (2007, p.100) assevera que "[...] um campo limítrofe a Arquitetura da Informação - e que deve ser mencionado - é o design de informação [...]”. Camargo e Vidotti (2011, p.18) alegam que o design de informação “[...] enfoca o conteúdo, ele é o design da apresentação da informação para facilitar a compreensão do usuário [...]”. Discutindo o design de informação, Lunin, Martin e Hastings (2009) salientam a importância da visualização da informação como um meio para a transformação de dados em visualidades, formas compreensíveis que agora são discutidas em universidades e institutos de pesquisa em todo o mundo.

Para Resmini e Rosati (2011), o design de informação seria uma abordagem centrada nas contribuições de Richard Soul Wurman, arquiteto e designer que cunhou o termo Arquitetura da Informação.

O design de interação contribui para tornar os produtos interativos e, assim, fornecer suporte às atividades cotidianas das pessoas. Significa criar experiências que melhorem e ampliem as formas como as pessoas trabalham, se comunicam e interagem utilizando produtos tecnológicos e de informação (Preece; Rogers; Sharp, 2005). As autoras supracitadas definem que duas metas devem ser alcançadas no design de interação: a primeira diz respeito à usabilidade que assegura a facilidade de uso de um produto, para que seja eficiente e agradável; a segunda seria a meta da experiência do usuário para possibilitar que os produtos informacionais sejam divertidos, esteticamente apreciáveis, motivadores.

Na compreensão do estudioso Villas-Boas (2000, p.13), o design gráfico é "[...] a atividade profissional e a consequente área de conhecimento cujo objeto é a elaboração de projetos para reprodução por meio gráfico por peças expressamente comunicacionais [...]". A seu ver, o produto do design gráfico agrupa elementos estético-formais ordenados numa perspectiva de projeto, criando a possibilidade efetiva de reprodução a partir de um original.

A abordagem arquitetural é subjacente à revolução tecnológica que descrevemos neste livro com base em Castells (1999). Inclusive Wurman (2001), um dos principais representantes da abordagem arquitetural, discute elementos dessa revolução e frisa 
como a internet modificou nosso estilo de vida e nossa maneira de fazer negócios; como as tecnologias emergentes provocam crises em alguns setores, mas, de modo geral, instalam-se sem desalojar as tecnologias antigas. ${ }^{4}$ Nesse entrelaçado de modificações sociotécnicas, o crescente quantitativo de informações criou necessidades de reflexão e revisão das formas de apresentação da informação, considerando a espacialidade que ela ocupa em ambientes digitais e não digitais. Wurman (2001) evidencia o impacto dos volumes informacionais no cotidiano das pessoas ao discutir a ansiedade que a informação e a não informação causam nos sujeitos.

A ansiedade de informação é causada pela distância cada vez maior entre o que compreendemos e o que achamos que deveríamos compreender. É o buraco negro existente entre os dados e o conhecimento, que aparece quando a informação não diz o que queremos saber. (Wurman, 2001, p.14)

Os questionamentos de Wurman (2001) sobre as formas de organizar a informação em espaços digitais e não digitais a fim de minimizar a ansiedade gerada nos usuários tentam ser respondidos a partir de elementos teóricos e conceituais advindos das áreas de sua formação.

A visão de Wurman é derivada de sua formação como arquiteto, e seu principal propósito é estender os conceitos-chave de organização de espaços desenvolvidos na arquitetura para espaços informacionais. (Siqueira, 2008)

Essa argumentação sustenta-se nos recursos indicados por Wurman para estruturar e mapear a informação para que possa ser utilizada com facilidade. Estruturar e mapear a informação, para

4 Wurman (2005) exemplifica que o DVD substituiu as fitas de vídeo, mas não as extinguiu. Cita que a imprensa escrita e a TV indicam a seus públicos os portais de internet em que é possível acessar informações sobre produtos e serviços apresentados em suas grades de programação. Trata-se de um contexto de polinização cruzada entre tecnologias antigas e recém-consolidadas. 
Wurman (1996), é uma atividade semelhante ao projeto de espaços organizados e estruturados pelo arquiteto tradicional.

Oliveira (2014) adverte que Wurman não é o único a utilizar aspectos da arquitetura e do design na Arquitetura da Informação e utiliza a teoria do conceito (Dahlberg, 1978) como critério para identificar a abordagem arquitetural nas concepções de AI elaboradas por outros autores.

Influenciados pela abordagem arquitetural e preocupados com o desenvolvimento de ambientes para a web, Herrans e Mateos (2004) argumentam que, enquanto na arquitetura os profissionais projetam construções e criam espaços físicos funcionais e adequados ao uso e às tarefas das pessoas, na Arquitetura da Informação, criam-se desenhos de espaços de informação funcionais para sanar as necessidades de informação das pessoas que acessam sites. $\mathrm{Na}$ citação de Herrans e Mateos (2004) os núcleos conceituais espaço, funcionalidades e desenhos mostram a ligação com as concepções de arquitetura e design já apresentadas neste livro (Oliveira, 2014).

A visão de Hagedorn (2000) também contém elementos da abordagem arquitetural. A seu ver, a AI é um articulado de arte e ciência da organização da informação que se concretiza por meio da investigação, da análise, do desenho e da implementação, com foco nas necessidades de informação das pessoas. Oliveira (2014) destaca, com base na teoria do conceito, os núcleos conceituais: arte, organização e desenho como evidências da abordagem arquitetural.

A visão arquitetural apresentada por Hagedorn (2000) é corroborada por Rosenfeld e Morville (2006, p.4, tradução nossa) ao conceituarem a AI como "[...] a arte e ciência de modelar experiências e produtos de informação para apoiar a usabilidade e encontrabilidade [...]" e, ainda, como "[...] o design estrutural de ambientes de informação compartilhados [...]”. Nos conceitos extraídos da obra de Rosenfeld e Morville (2006) percebe-se que os autores também se apoiam na noção do belo ao associar a AI à arte e ainda fazem referência, de forma subliminar, à funcionalidade quando associam a $\mathrm{AI}$ à usabilidade e à encontrabilidade. Os núcleos conceituais arte e função, no primeiro conceito, e design estrutural, no 
segundo conceito, estão presentes por influência de uma abordagem arquitetural (Oliveira, 2014).

Nos estudos realizados por Everden e Everden (2003), encontramos a AI particionada em três gerações. Esses autores descrevem que a primeira geração tem foco nos sistemas de aplicações que não funcionavam na $w e b^{5}$ e que se utilizavam de analogias como a arquitetura de construção e diagramas 2D simples ou frameworks para fornecer uma visão arquitetural dos produtos de informação. A influência da abordagem arquitetural pode ser identificada nesta forma de enxergar a AI a partir do núcleo conceitual "arquitetura de construção".

Para Chiou (2003), a Arquitetura da Informação apropria-se da habilidade arquitetônica tradicional de planejar e relacionar elementos, orientando-se pelas similaridades que existem entre os ambientes de informação digital e os ambientes analógicos. Vemos aqui uma concepção de AI que incorpora dois elementos conceituais importantes: o projeto e o espaço. Quando o autor insere na AI a habilidade de planejar e de relacionar elementos, está fazendo menção à atividade de projeto da arquitetura e do design. Ao utilizar o termo "ambientes" é feita uma menção subliminar à espacialidade.

Taylor (2004) afirma que os arquitetos criam projetos de edifícios e estruturas para servirem às necessidades das pessoas incorporando beleza e funcionalidade. Para esse autor, o arquiteto da informação investiga as necessidades de acesso e uso da informação para modelar interfaces de modo que sejam funcionais e agradáveis ao usuário quando este se desloca nos ambientes de informação. Oliveira (2014) sinaliza os núcleos conceituais forma e função como vetores que apontam para a abordagem arquitetural.

As ideias de Hubert-Miller e Arbogast (2006) são visivelmente influenciadas pela abordagem arquitetural - inclusive, permitem-nos compreender que tanto a arquitetura quanto a Arquitetura da Informação empregam as noções de lugar e espaço. A seu ver, a arquitetura trata de um conjunto de atributos de um espaço, e a Arquitetura da Informação trata de um conjunto de atributos de

5 Sistemas standalone. Sistemas que funcionavam em redes locais e intranets. 
um espaço em que experiências informacionais ocorrem reunindo contexto, comunicação e conteúdo.

Nas afirmações de Camargo e Vidotti (2011), percebemos que a abordagem arquitetural absorve princípios da arquitetura e do design. Para essas autoras, a AI incorpora:

- beleza, a qual está expressa nos elementos externos do ambiente de informação digital através da estética e aparência;

- funcionalidade, que é expressa nos elementos internos do ambiente de informação digital reforçando a utilidade e praticidade.

De forma sintética, podemos dizer que a abordagem arquitetural se efetiva numa dialética entre o belo e o funcional, fazendo com que aspectos relacionados à arquitetura e ao design sejam abrigados no interior dessa abordagem. Trata-se de uma abordagem que compreende a Arquitetura da Informação como um campo que desenvolve padrões e orientações arquiteturais para tornar os espaços de informação organizados e acessíveis. Ela concebe o arquiteto da informação como sujeito responsável por criar estruturas e desenhos que possam oferecer ordem no espaço dos dados, tornando o acesso às informações mais simples, mais direto, e, finalmente, mais compreensível (Resmini; Rosati, 2011).

\section{Abordagem sistêmica}

Ao longo da história da Arquitetura da Informação, os ambientes de informação digital têm sido tratados, de forma recorrente, a partir de uma racionalidade sistêmica. O paradigma sistêmico age na Arquitetura da Informação, fornecendo modos de pensar que resultam de uma fundamentação na teoria geral dos sistemas e de uma necessidade de atuação no campo dos sistemas de informação.

Oliveira e Vidotti (2012) defendem que os estudos clássicos da Arquitetura da Informação se aportam em uma epistemologia sistêmica, influenciada pela teoria geral dos sistemas do biólogo alemão Ludwig von Bertalanffy (Bertalanffy, 1975). Trata-se de 
um conjunto de pesquisas publicadas e ações práticas executadas sob a influência da obra de Morville e Rosenfeld (2006) e que racionalizam os ambientes de informação digital de forma sistêmica (sistemas de navegação, sistemas de rotulagem, sistemas de organização, sistemas de busca e sistemas de representação) (Oliveira; Vidotti, 2012).

Discutindo o sistemismo como desenho epistêmico, os mesmos autores explicam que os objetos ou fenômenos de pesquisa são investigados a partir de suas partes. Estudos e pesquisas ancorados nesta epistemologia analisam a natureza dos sistemas e a maneira como se inter-relacionam, investigam a inter-relação entre os sistemas em diferentes espaços e, assim, tornam possível conhecer/ compreender o objeto ou fenômeno de pesquisa em sua integralidade (Oliveira; Vidotti, 2012).

$\mathrm{Na}$ abordagem sistêmica, a Arquitetura da Informação trata os ambientes de informação digital como um conjunto de sistemas, e cada sistema é um "[...] conjunto de elementos interdependentes, ou um todo organizado, ou partes que interagem formando um todo unitário e complexo (Batista, 2004, p.14 apud Camargo, 2010, p.67).

Os sistemas de informação são apresentados por Resmini e Rosati (2011) como um contexto que influenciou as pesquisas em AI, desenvolvidas na década de 1980. Tais pesquisas estavam preocupadas em maximizar o processamento de dados e informações para solver os problemas de gestão da informação no campo dos negócios e as necessidades logísticas das organizações.

A Arquitetura da Informação estaria, então, comprometida com a eficiência e a eficácia de um sistema de informação (SI), compreendido com base em Turban, McLean e Wetherbe (1996) como sistema que integra: pessoas, procedimentos, dados/informação, componentes de tecnologias de informação e comunicação (hardwares, softwares) e elementos de telecomunicações para recolher, processar, armazenar, analisar e distribuir informação como recurso útil à tomada de decisões.

Nos sistemas de informação, existem os inputs (dados, instruções) e outputs (relatórios, cálculos). O SI processa os inputs para 
produzir outputs que serão usados no processo decisório, como input para outros sistemas de informação ou, ainda, como input de retroalimentação para o mesmo sistema de informação (Turban; McLean; Wetherbe, 1996).

Recorremos a Oliveira (2014) para apresentar conceitos, visões e proposições relacionadas à Arquitetura da Informação com o intuito de visualizar a abordagem sistêmica na AI.

Conforme apresentado neste livro, a abordagem arquitetural está presente na visão de Morville e Rosenfeld (2006), porém não é a única abordagem que pode ser identificada nas compreensões de AI que os autores adotam. Para Morville e Rosenfeld (2006) a AI também seria "[...] a combinação de sistemas de organização, rotulagem, busca e navegação dentro de websites e intranets." (Morville; Rosenfeld; 2006, p.4, tradução nossa). Tal conceito repercute intensamente nos estudos e nas práticas de $\mathrm{AI}$ posteriores à publicação da obra Information Architecture for the World Wide Web, de Morville e Rosenfeld, em que os autores sistematizam, a partir de um paradigma sistêmico, uma forma de enxergar e analisar os sites da web e intranets como "um todo", como um ambiente de informação digital que se estrutura pela combinação "de partes", pela justaposição de subsistemas categorizados como organização, rotulagem, busca e navegação (Oliveira, 2014).

A compreensão de Carter (1999) sobre a AI também pode ser categorizada como sistêmica. Para Carter (1999), a AI é um caminho holístico de planejamento que atende as necessidades de organização da informação com objetivo de evitar duplicação e dispersão de dados. Para o autor, Arquitetura da Informação é um termo utilizado coletivamente para descrever os diversos componentes da infraestrutura global de informações de um modelo de negócios, preocupando-se principalmente com a arquitetura de dados, a arquitetura de sistemas e a arquitetura de computadores (Carter, 1999). Na visão de Carter, os núcleos conceituais "holismo" e "infraestrutura global" remetem a significados como integralidade e completude e, por conseguinte, referem-se ao todo; o núcleo conceitual "componentes" remete "às partes" do sistema (Oliveira, 2014). 
Também é possível visualizar a abordagem sistêmica na compreensão de AI apresentada por Everden e Everden (2003), para quem o aumento da complexidade e a densidade dos sistemas de informação colaboraram no desenvolvimento de programas com arquiteturas mais amplas que consideram o escopo, o impacto e os processos organizacionais. Assim, a Arquitetura da Informação seria um mecanismo para definição, controle e integração das interfaces e camadas de sistema. Esta última afirmação é a chave para a identificação da abordagem sistêmica. Ao apresentar a AI como mecanismo de estruturação de "interfaces e camadas", os autores referem-se às partes que integradas de forma holística substanciariam "o todo".

$\mathrm{Na}$ segunda geração de AI proposta por Everden e Everden (2003), a informação é entendida como recurso corporativo, e as práticas em AI se voltavam para a definição explícita de princípios e teorias para o desenvolvimento de arquiteturas multidimensionais de sistemas de informação (Everden; Everden, 2003). Na segunda geração, os autores descrevem que o foco da AI eram os "[...] sistemas como conjuntos integrados de componentes dentro de uma organização individual” (Everden; Everden, 2003, p.95, tradução nossa). Nessa proposição, a articulação dos termos "conjuntos", "integrados" e "componentes" mostra a presença da abordagem sistêmica. No contexto descrito pelos autores, a AI volta-se mais para as soluções tecnológicas, em vez de atuar no uso da informação nas organizações.

Everden e Everden (2003) apresentam a terceira geração da AI como uma alternativa para as limitações da primeira e da segunda geração, sobretudo como uma necessidade de fazer a Arquitetura da Informação voltar-se para os sujeitos. Os autores asseveram que "[...] aplicando esta distinção fica mais fácil o trabalho do arquiteto da informação para compreender as necessidades do usuário" [...] (Everden; Everden, 2003, p.95, tradução nossa).

A abordagem sistêmica influencia a AI, principalmente nas aplicações no campo dos sistemas de informação, porém incorpora preocupações para além das necessidades de informação dos sujeitos e das organizações, trazendo preocupações estritamente técnicas. 
Oliveira (2014) afirma que a abordagem sistêmica é fundamental na segunda geração da classificação de Everden e Everden (2003), mas as novas demandas, inclusive em contextos organizacionais, aproximam a terceira geração da AI à abordagem pervasiva.

Na fronteira sistêmica McGee e Prusak (1994) apresentam a Arquitetura da Informação como uma metáfora utilizada por teóricos e especialistas em projetos de sistemas para referir-se aos modelos de organização para a geração e o processamento de dados significativos para uma organização. Assim, teria como objetivo modelar um mapa de dados organizacionais e suas relações e fornecer subsídios para construção de sistemas de informação.

O sistemismo está presente nas ideias de Brancheau e Wetherbe (1986), que discutem a AI no plano do desenvolvimento dos sistemas de informação empresariais. A AI é interpretada por esses autores como

[...] um diagrama ou plano para modelagem dos requisitos globais de informação de uma empresa. Ela provê uma maneira para mapear as necessidades de informação de uma organização, relacioná-las com os processos de negócios específicos e documentar suas inter-relações. O mapeamento do processo de informação é então usado para guiar o desenvolvimento de aplicações e facilitar a integração e compartilhamento de dados. Uma arquitetura de informação fornece uma base pró-ativa para o desenvolvimento de sistemas de informação [...]. (Brancheau; Wetherbe, 1986, p.454, tradução nossa)

Para Oliveira (2014), a proposição supracitada mostra uma Arquitetura da Informação que mapeia, modela e diagrama a estrutura informacional de uma organização para orientar o desenvolvimento de sistemas de informações empresariais.

Na mesma linha interpretativa, Camargo e Vidotti (2011) evidenciam que com a valorização dos sistemas de informação enquanto fator estratégico para vantagem competitiva nas organizações, a 
AI passou a ser um requisito para facilitar o processo decisório e sanar as necessidades de informação dos sujeitos da organização.

Camargo (2010) assegura que a Arquitetura da Informação fornece uma base teórica para tratar aspectos informacionais, estruturais, navegacionais, funcionais e visuais de websites, utilizando métodos e procedimentos adequados para auxiliar o desenvolvimento de tais ambientes e potencializando o acesso aos conteúdos. A concepção da autora dialoga com o conceito sistêmico de AI pensado por Morville e Rosenfeld (2006).

Conforme defende Oliveira (2014), uma abordagem nem sempre atua de forma estanque, inclusive é possível notarmos a justaposição de abordagens distintas atuando em uma única pesquisa ou ainda influenciando a forma de conceituar um objeto ou fenômeno de investigação. O que acabamos de expor ocorre na visão de Vidotti, Cusin e Corradi (2008, p.182) quando afirmam que a

Arquitetura da Informação enfoca a organização de conteúdos informacionais e as formas de armazenamento e preservação (sistemas de organização), representação, descrição e classificação (sistema de rotulagem, metadados, tesauro e vocabulário controlado), recuperação (sistema de busca), objetivando a criação de um sistema de interação (sistema de navegação) no qual o usuário deve interagir facilmente (usabilidade) com autonomia no acesso e uso do conteúdo (acessibilidade) no ambiente hipermídia informacional digital. (Vidotti; Cusin; Corradi, 2008, p.182).

No conceito supracitado, Oliveira (2014) identifica as seguintes categorias sistêmicas: sistema de organização, sistema de busca, sistema de rotulagem, sistema de navegação e usabilidade, que são núcleos conceituais da concepção de AI apresentada por Morville e Rosenfeld (2006). Tal fato sinaliza a presença da abordagem sistêmica. Entretanto, Vidotti, Cusin e Corradi (2008) trazem elementos que ampliam a visão clássica de Morville e Rosenfeld (2006), elementos que subvertem a lógica conceitual sistêmica por uma lógica conceitual influenciada pela Ciência da Informação, locus discursivo de 
Vidotti, Cusin e Corradi. A visão de AI ora discutida acolheu uma dupla influência: de um lado, a contribuição da abordagem sistêmica; por outro lado, amplia a visão de AI incorporando núcleos conceituais da abordagem informacional, tecida na Ciência da Informação.

\section{Abordagem informacional}

O enfoque que orienta os estudos e as práticas da Arquitetura da Informação numa relação direta com o campo da biblioteconomia e da Ciência da Informação pode ser denominado abordagem informacional. Tal abordagem recebe contribuição efetiva de Petter Morville $^{6}$ e Louis Rosenfeld ${ }^{7}$ que têm formação em biblioteconomia e Ciência da Informação pela Universidade de Michigan. Em função da formação dos autores, suas contribuições apresentam nítidas marcas biblioteconômicas e da Ciência da Informação.

Nossos conhecimentos em Ciência da Informação e biblioteconomia têm se mostrado muito úteis para lidar com as relações entre as páginas e outros elementos que compõem um site inteiro. Bibliotecários têm uma longa história em organizar e prover acesso à informação e são treinados para trabalhar com busca, navegação e tecnologias de indexação. (Morville; Rosenfeld, 2006, p, 19, tradução nossa)

Inclusive, ao argumentarem sobre as formações necessárias para atuar como arquiteto da informação, deixam claro que não é necessário ter uma formação específica, porém muitos arquitetos da informação têm escolhido programas de pós-graduação relacionados à biblioteconomia, à Ciência da Informação ou à interação humano-computador (IHC) (Morville; Rosenfeld, 2006).

6 Cf. biografia disponível em: <http://semanticstudios.com/about/>. Acesso em: 1 out. 2013.

7 Cf. biografia disponível em: <http://louisrosenfeld.com/biography/>. Acesso em: 1 out. 2013. 
A afirmação de Morville e Rosenfeld (2006) tem sido corroborada no Brasil em estudos desenvolvidos por Oliveira e Vidotti (2013) e Vidotti, Oliveira e Lima (2013). Esses autores têm constatado que a Arquitetura da Informação está presente como disciplina na grade curricular formal de cursos brasileiros de graduação em biblioteconomia, bem como em cursos de pós-graduação em Ciência da Informação.

Em texto que trata dos arrolamentos interdisciplinares entre os sistemas da Arquitetura da Informação e alguns campos do conhecimento, Oliveira e Vidotti (2012) destacam que a biblioteconomia é um campo útil para tratar na AI o arcabouço de pressupostos teóricos e técnicos da biblioteconomia, ou seja, sua preocupação histórica com coleta, preservação, organização, acesso e uso de informações para os diversos públicos fornece subsídios para o projeto ambientes informacionais digitais.

Projetar os blocos de informações em um ambiente informacional digital, em função de critérios previamente estabelecidos, pode ser orientado pelas práticas biblioteconômicas de gestão, representação temática e descritiva, recuperação e uso da informação, devidamente adaptadas para o mundo digital. (Oliveira; Vidotti, 2012)

Quando tratamos da abordagem sistêmica, apresentamos um conceito de arquitetura defendido por Vidotti, Cusin e Corradi (2008) e lá observamos que esse conceito é uma releitura do conceito de AI apresentado por Morville e Rosenfeld (2006) com evidente influência do paradigma sistêmico. Todavia, tal conceito também incorpora a abordagem informacional, visto que traz categorias como organização, armazenamento, preservação, metadados, representação, descrição, classificação, tesauro, vocabulário controlado, recuperação, acesso e uso, usabilidade e acessibilidade. Trata-se de categorias largamente estudadas e investigadas nas áreas de biblioteconomia e Ciência da Informação.

Morville e Rosenfeld (2006) impelem à AI a tônica dos paradigmas sistêmico e informacional. Para tais autores, praticar Arquitetura da Informação no mundo real significa triangular o contexto, os conteúdos e os comportamentos dos usuários de um ambiente 
de informação digital. O conteúdo tem uma materialidade capaz de dar substância ao ambiente de informação, e as informações devem ser representadas de forma adequada para que seus conteúdos informacionais sejam recuperados em função das necessidades de informação dos usuários.

Oliveira (2014) destaca a abordagem informacional na obra de Morville e Rosenfeld (2006) e frisa que os aparatos teóricos da biblioteconomia e Ciência da Informação são uma recidiva ao longo da obra. Em diversas partes do texto, os autores fazem referência à biblioteca, conforme fragmento a seguir:

Um antigo catálogo de fichas de biblioteca é relativamente homogêneo. Ele organiza e provê acesso a livros. Ele não provê acesso a capítulos em livros ou coleções de livros. Ele não pode prover acesso a revistas ou vídeos. Essa homogeneidade permite um sistema de classificação estruturado. (Morville; Rosenfeld, 2006, p.56, tradução nossa)

A biblioteca também é citada como exemplo para contextualizar a utilização de esquemas de organizações orientados por audiência.

Encontramos nesta uma abordagem útil para o site oficial da Biblioteca de Michigan. A Biblioteca de Michigan tem três públicos principais: os membros do legislativo estadual e suas equipes, bibliotecas de Michigan e seus bibliotecários, e os cidadãos de Michigan. As informações disponíveis a partir do site são diferentes para cada um desses públicos, por exemplo, cada um tem uma política de circulação muito diferente. (Morville; Rosenfeld, 2006, p.154, tradução nossa)

Ao longo da obra supracitada, Oliveira (2014) identificou núcleos conceituais, como: biblioteca, catálogo, biblioteconomia, Ciência da Informação, gestão da informação, arquivos de autoridade, classificação decimal de Dewey, classificação facetada, tesauros, vocabulários controlados, organização da informação, nuvens de 
informação, modelos informacionais, mapeamento de informações, tecnologia da informação, entre outros. Esses núcleos conceituais são evidências da influência da abordagem informacional em Morville e Rosenfeld (2006). Inclusive, Resmini e Rosati (2011) reconhecem que eles são os principais representantes da abordagem orientada pela biblioteconomia e Ciência da Informação, que nós chamamos aqui de abordagem informacional.

\section{Abordagem pervasiva}

O debate relacionado à emergência de um novo momento na Arquitetura da Informação tem sido marcado pela necessidade de investigar e propor soluções para problemas informacionais e tecnológicos caracterizados pela pervasividade e ubiquidade. Para tratar da abordagem pervasiva, considerando seu caráter de ruptura, de novidade e de emergência, Oliveira (2014) destaca um conjunto de mudanças, de anomalias e de novos desafios que tornam significativo o surgimento e a expansão de uma Arquitetura da Informação Pervasiva.

Os subsídios teóricos para tratar o itinerário de mudanças que fazem emergir a Arquitetura da Informação Pervasiva advêm da obra de Kuhn (2003). Segundo Oliveira (2014), a transição para uma nova abordagem da AI tem um funcionamento semelhante às mudanças de paradigmas teorizadas por Kuhn (2003).

Na visão de Oliveira (2014), as noções de revolução apresentadas por Kuhn (2003) no contexto da ciência e por Castells (1999) no contexto da tecnologia se complementam e são oportunas para explicar o que tem ocorrido com a Arquitetura da Informação desde o início dos anos 2000. Referimo-nos aos novos tipos de fenômenos informacionais, anômalos e pouco passíveis de serem tratados pelos paradigmas arquitetural, sistêmico ou informacional da AI. O surgimento de novos e desafiadores problemas relacionados à Arquitetura da Informação suscitou uma revisão do que já estava posto sobre a AI. De modo que uma nova forma de enxergar a AI tem 
sido desenvolvida pelos pesquisadores Andrea Resmini e Luca Rosati, com destaque para o livro Pervasive information architecture: designing cross-channel user experiences, publicado pelos referidos autores em 2011. Nele, os autores sinalizam que a abordagem centralizada na Ciência da Informação, a qual Oliveira (2014) chamou de abordagem informacional, difundida de forma significativa por Morville e Rosenfeld (2006), apresentou um importante sucesso e impactou positivamente os projetos e as avaliações de ambientes de informação digital. Contudo, o cenário delineado a partir dos anos 2000 trouxe mudanças consideráveis no protagonismo dos sujeitos em ambientes de informação digital e no tipo de experiência que esses ambientes podem fornecer, sugerindo um diálogo da AI com a computação ubíqua e o design de serviços (Resmini; Rosati, 2011).

Evidencia-se uma busca por novos caminhos para tratar os problemas emergentes e solver, via Arquitetura da Informação, o que pode ser categorizado como as anomalias arrazoadas por Kuhn (2003), aquelas que são capazes de enfraquecer uma abordagem, embora nem sempre ela seja totalmente abandonada. Tais anomalias conduzem a uma mudança de paradigma [ou abordagem] e afetam profundamente os conhecimentos existentes (Kuhn, 2006).

Essas anomalias e mudanças vinculam-se, ligam-se e conectam-se ao processo tecnológico evolutivo pós-industrial. Trata-se de um continuum da revolução tecnológica descrita por Castells (1999) que, a partir dos anos 2000 se propaga por meio de novos problemas tecnológicos e de pesquisa tecnológica, intensificando-se em função dos novos comportamentos dos sujeitos que usam e produzem informação cotidianamente por meio das TIC, das novas demandas nos diversos setores da sociedade (Oliveira, 2014).

Em um cenário de permanentes mudanças tecnológicas, os comportamentos dos sujeitos também se modificaram, tornando-os produtores de informação e fazendo ganhar força, na literatura sobre TIC, o termo prosumer para designar os sujeitos que acessam, usam, criam e recriam informação digital, ou seja, consomem e produzem conteúdos digitais. Devemos considerar nesse contexto o intenso uso de tecnologias móveis como um vetor que complexifica 
o cenário de acesso, o uso e a produção de informações digitais, pois exige um redesenho dos aspectos de organização e representação da informação digital e das fronteiras computacionais (Resmini; Rosati, 2011). A informação digital está disponível em diferentes dispositivos e, portanto, necessita ser representada e organizada de modo fluido para que se adeque responsivamente ao dispositivo e ao contexto de uso.

Discutindo os comportamentos de consumo dos sujeitos, Resmini e Rosati (2011) apresentam estudos realizados nos Estados Unidos e na Europa que mostram padrões de consumo relacionados a uma espécie de cruzamento de informações como forma de potencializar o conhecimento do consumidor sobre os produtos que deseja adquirir. Os sujeitos utilizam a web e/ou dispositivos móveis para acessar informações sobre produtos que desejam comprar em lojas físicas ou em e-commerces. Os estudos demonstram que a mídia televisiva, os jornais, as revistas e a internet têm sido utilizados, por vezes simultaneamente, na aquisição de informações para realização de compras de produtos físicos ou digitais.

O que fora exemplificado no âmbito dos padrões de consumo também ocorre em outros setores da sociedade. Em uma biblioteca, por exemplo, um usuário pode interagir com o catálogo on-line e averiguar se há títulos que lhe interessam para posteriormente dirigir-se a ela e retirar os títulos, considerando que esse é um processo que começa digital e se torna físico.

No campo da saúde podemos citar a possibilidade de um paciente fazer o agendamento de um exame no site do laboratório que escolheu, posteriormente se dirigir ao laboratório na hora marcada e receber no comprovante de realização do exame, um login e uma senha para ter acesso aos resultados no seu computador por meio do site da clínica. Esse processo pode ser descrito como digital-físico-digital.

Resmini e Rosati (2011) chamam atenção para as experiências tecnológicas voltadas para hibridização de aspectos físicos e digitais em ambientes de informação: 
Nossas atividades do dia a dia estão mudando. Elas estão se tornando experiências cross-channel, exigindo que nos movamos não apenas de um meio para outro, de um dispositivo para outro, mas em todos os domínios: algo que começa digital, como um e-mail dizendo que um produto esperado está agora à venda, acaba sendo físico quando vamos pegá-lo na loja de varejo. Ou poderia ser o contrário, com algo sendo fornecido ou enviado para o nosso endereço, até mesmo um endereço eletrônico, após uma visita a um escritório. (Resmini; Rosati, 2011, p.41, tradução nossa)

As experiências cross-channel atualmente vivenciadas têm suscitado questionamentos sobre a Arquitetura da Informação em ambientes analógicos e digitais, no sentido de investigar formas para integrar esses tipos de ambientes por meio do compartilhamento de camadas de informação comuns, no sentido de promover experiências informacionais holísticas, ecológicas e pervasivas.

Em artigo publicado em 2009 na Association for Information Science and Technology (ASIS\&T), David Potente e Erika Salvini da University for Foreigners Perugia, tratam de estudos de caso sobre integração de ambientes analógicos e digitais argumentando que a concepção de um espaço físico pode e deve tirar proveito da arquitetura de informação e dos seus entregáveis, em particular, ao projetar um modelo integrado de AI para esses ambientes (Potente; Salvini, 2009). Nesse estudo, os autores apresentam os casos da Apple e do Ikea, ressaltando como suas arquiteturas da informação integram aspectos físicos no ambiente digital e vice-versa, incorporando as experiências bridge. Optamos por usar os termos cross-channel e bridge em língua inglesa por compreender que seus correspondentes literais em língua portuguesa - cruzamento de canais e ponte, respectivamente - são semanticamente insuficientes para atender ao conceito de "experiência cross-channel" e "experiência bridge".

Após investigar de forma aprofundada a arquitetura do site da Apple e a arquitetura na loja de varejo Apple, os autores destacaram: 
[...] o papel da Arquitetura da Informação na construção de experiências bridge. AI pode atravessar vários contextos de experiência com o objetivo de definir um modelo único de interação humano-informação por meio de uma organização adequada dos fluxos de informação e tarefas. (Potente; Salvini, 2009, p.33, tradução nossa)

Para expor os achados da pesquisa de maneira didática, Potente e Salvini (2009) apresentam um mapeamento que mostra uma camada que intersecciona elementos de informação, devidamente categorizados para integrar aspectos físicos e digitais da Apple, conforme pode ser visto na Figura 6.

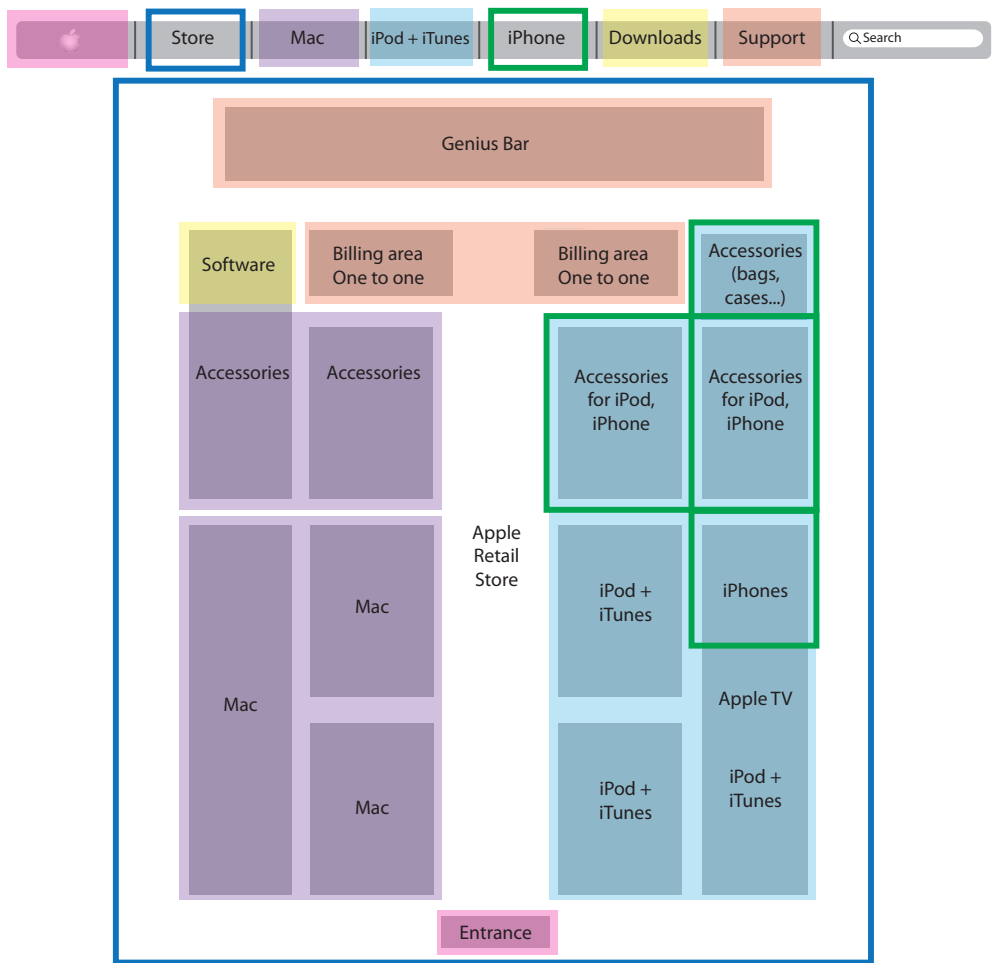

Figura 6 - Mapa de correspondências entre a taxonomia do site da Apple e colocação de produtos no interior da loja Apple.

Fonte: Potente e Salvini (2009, p.33). 
A Figura 6 demonstra um exemplo de eficiência e eficácia no cruzamento de AI entre dois ambientes: o site de vendas e o espaço físico de varejo da Apple. No mapeamento, as cores são utilizadas para demonstrar os elementos taxonômicos do ambiente digital e a distribuição de produtos e setores na loja física. O destaque em rosa mostra a correspondência entre a entrada da loja física e o botão home rotulado iconicamente com a logomarca da Apple. A marcação com uma linha azul, no site refere-se à aba que dá acesso à compra de produtos e na loja física corresponde a toda a espacialidade usada para expor produtos e serviços. O destaque em roxo marca no site o acesso a informações sobre o Mac e corresponde, na loja física, à área reservada para mostrar os computadores Mac. A região em azul evidencia no site a camada que trata do iPod e do iTunes, correspondendo à área destinada ao mostruário de iPod, produtos iTunes e Apple TV da loja física. A área reservada na loja física para os iPhones corresponde à aba denominada iPhones no site, ambas marcadas com uma linha verde. Temos ainda destacada a camada de downloads que corresponde na loja física ao espaço destinado às aplicações de software - essa correspondência foi destacada com a cor amarela. Por fim, temos na marcação laranja a área de suporte técnico rotulada no site pelo termo support, que corresponde à bancada genius para suporte a produtos, no fundo de uma loja de varejo Apple.

A integração e entrecruzamento de elementos informacionais no site da Apple e em sua loja física facilita a experiência do usuário, reduz a possibilidade de desorientação e aumenta o envolvimento dos usuários na aquisição de produtos e serviços. Trata-se de uma arquitetura de informação transversal, no sentido de que ela faz cruzar marcações cognitivas e sobrepõe marcações de informação por meio do reconhecimento de elementos do ambiente físico que estão no ambiente digital e/ou vice-versa. É nesse contexto que se realizam as experiências bridge, definidas como um

[...] modelo mental único através do qual o usuário pode manter uma série de conceitos, assegurando assim uma interação homogênea. Para transmitir essa homogeneidade, as pessoas precisam de sinais e pistas que ligam o espaço digital ao espaço físico. Con- 
teúdos textuais podem oferecer uma grande ajuda para obter esta consistência. (Potente; Salvini, 2009, p.35, tradução nossa) ${ }^{8}$

Os estudos de caso apresentados no artigo de Potente e Salvini (2009) mostram que os usuários coletam informações na web para usá-las no mundo físico e vice-versa. Os autores enfatizam o papel de usuários no melhoramento dos processos arquiteturais e de design. Desse modo, os usuários podem ajudar fazendo sugestões sobre o que precisam em termos de funções e conteúdo, bem como sobre a forma como reconhecem informações e interagem com elas. Trata-se de adotar uma estratégia de design participativo e envolver os usuários finais de forma pró-ativa no processo de concepção (Potente; Salvini, 2009).

O Quadro 1 mostra uma síntese de ocorrências que, segundo Resmini e Rosati (2011), fomentaram o surgimento da Arquitetura da Informação Pervasiva, enquanto nova abordagem na Arquitetura da Informação.

Quadro 1 - Fatos propulsores da Arquitetura da Informação Pervasiva

\begin{tabular}{|c|l|}
\hline $\begin{array}{c}\text { Arquiteturas } \\
\text { da informação } \\
\text { tornam-se } \\
\text { ecologias }\end{array}$ & $\begin{array}{l}\text { Quando diferentes mídias e contextos estão entrelaçados } \\
\text { com força, nenhum artefato pode ficar como uma } \\
\text { entidade isolada. Cada artefato torna-se um elemento } \\
\text { de uma ecologia maior. Todos esses artefatos têm vários } \\
\text { links ou relacionamentos uns com os outros e têm de ser } \\
\text { concebidos como parte de um processo único e contínuo } \\
\text { de experiência do usuário. }\end{array}$ \\
\hline $\begin{array}{c}\text { Usuários tornam- } \\
\text {-se mediadores }\end{array}$ & $\begin{array}{l}\text { Os usuários são mediadores nas ecologias e produzem } \\
\text { ativamente novos conteúdos ou corrigem o conteúdo } \\
\text { existente. A tradicional distinção entre autores e } \\
\text { leitores, ou produtores e consumidores, torna-se sutil, } \\
\text { a ponto de ser inútil e vazia de significado. }\end{array}$ \\
\hline
\end{tabular}

Continua

8 Bridge experience is defined by a unique mental model the user can keep through a range of concepts, thus ensuring homogeneous interaction. To convey this homogeneity, people need signals and cues connecting the digital world to the physical space. Textual contents can offer a great help to obtain this consistency (Potente; Salvini, 2009, p.35). 


\begin{tabular}{|c|l|}
\hline $\begin{array}{c}\text { Estático torna-se } \\
\text { dinâmico }\end{array}$ & $\begin{array}{l}\text { O papel ativo desempenhado pelos usuários/ } \\
\text { mediadores torna os conteúdos eternamente } \\
\text { inacabados, em constante mudança, perpetuamente } \\
\text { abertos ao aperfeiçoamento e manipulação. }\end{array}$ \\
\hline $\begin{array}{c}\text { Dinâmico torna-se } \\
\text { híbrido }\end{array}$ & $\begin{array}{l}\text { Essas novas arquiteturas abraçam diferentes domínios } \\
\text { (analógicos, digitais e híbridos), diferentes tipos de } \\
\text { entidades (dados, itens físicos e pessoas) e os diferentes } \\
\text { meios de comunicação. Todas as experiências são } \\
\text { experiências bridge ou cross-media, abrangendo } \\
\text { ambientes distintos. }\end{array}$ \\
\hline $\begin{array}{c}\text { Horizontal } \\
\text { prevalece sobre } \\
\text { vertical }\end{array}$ & $\begin{array}{l}\text { Em arquiteturas abertas e em constante mudança, os } \\
\text { modelos hierárquicos (top down) são difíceis de manter } \\
\text { e de dar suporte, como os usuários empurram as } \\
\text { arquiteturas em direção à espontaneidade, às estruturas } \\
\text { efêmeras ou temporárias de significado e à mudança } \\
\text { constante. }\end{array}$ \\
\hline $\begin{array}{c}\text { Design de produto } \\
\text { torna-se o design } \\
\text { da experiência }\end{array}$ & $\begin{array}{l}\text { Quando cada artefato (seja conteúdo, produto ou } \\
\text { serviço) é parte de uma ecologia maior, o foco muda de } \\
\text { como criar itens únicos para como criar experiências de } \\
\text { processo. }\end{array}$ \\
\hline $\begin{array}{c}\text { Experiências } \\
\text { tornam-se } \\
\text { experiências cross- } \\
\text {-media }\end{array}$ & $\begin{array}{l}\text { Múltiplas experiências bridge conectam mídias, } \\
\text { ambientes e a ecologia ubíqua, um processo único em } \\
\text { que todas as partes contribuem para uma experiência de } \\
\text { usuário global e sem emendas. }\end{array}$ \\
\hline
\end{tabular}

Fonte: Adaptado de Resmini e Rosati (2011, p.52-4).

O que apresentamos no Quadro 1 está integrado à conjuntura pós-moderna, com marcações sociotécnicas que reposicionam os sujeitos no que diz respeito ao uso das TIC. O que Resmini e Rosati (2011) apresentam são percepções recortadas do exercício profissional como arquitetos da informação e demonstram suas preocupações em justificar, de forma objetiva e inteligível, a Arquitetura da Informação Pervasiva.

De forma objetiva, salientamos que a Arquitetura da Informação Pervasiva é uma abordagem atual que estuda as ecologias informacionais complexas, sobretudo os processos de hibridização dos lugares humanos, digitais e não digitais, em que os sujeitos vivem, trabalham e divertem-se. 


\section{3 \\ ARQUITETURA DA INFORMAÇÃo PERVASIVA}

Como requisito para aprofundar a Arquitetura da Informação Pervasiva, trataremos da pervasividade, interligando-a à noção de ubiquidade que, no contexto tecnológico, também dialoga com a responsividade. Para tanto, tratamos a tríade pervasividade, ubiquidade e responsividade a partir de uma metáfora elaborada por Oliveira (2014).

Uma represa ou barragem armazena massas de água em função da escassez, da produção de energia, do abastecimento de cidades, da defesa contra enchentes, entre outros objetivos. A ideia básica é fazer uma barreira artificial para controle do fluxo da água num leito, para tanto possui dispositivos que permitem a maior ou menor passagem da água. A noção de pervasividade pode ser conectada à metáfora do rompimento de uma represa, cuja ocorrência faz a água se espalhar e invadir os espaços que encontrar no seu transcurso. A natureza pervasiva da água represada se assemelha à natureza pervasiva da informação. Podemos sugerir que, da mesma forma como a água da barreira que se rompeu invade espaços, casas, sítios, fazendas e tudo que encontrar pela frente, a informação digital invadiu a sociedade e a cultura, de modo que está presente nos espaços, ambientes analógicos e digitais, lugares web e não web, em diversos tipos de dispositivos, e modifica a vida dos sujeitos da 
mesma forma que a água da barreira que se rompeu modifica a vida dos sujeitos que encontrar pela frente (Oliveira, 2014).

O rompimento da represa faz a água invadir tudo aquilo que encontrar, rapidamente é incorporada aos espaços, aos objetos, às casas, ao solo - tudo fica molhado. Ao menos uma fina camada se instala na superfície das coisas, de modo que a água se torna presente em tudo que encontrar e isto nos remete novamente à informação, que também se incorpora aos ambientes, ao cotidiano e ao comportamento dos sujeitos. Quando a água molha, integra-se aos corpos assim como a informação se integra aos espaços e aos ambientes, remetendo-nos à ideia de ubiquidade. A informação é ubíqua e está incorporada aos múltiplos espaços, ambientes e comportamentos das pessoas (Oliveira, 2014).

A última ideia que queremos tratar de forma metafórica é a de responsividade. Ao integrar-se aos ambientes a água será melhor absorvida dependendo das características do material que entra em contato com ela - se mais poroso absorve mais água, se mais denso e compacto absorve menos água, e dependendo da dureza do objeto a água pode nem passar da camada externa e rapidamente evaporar. Analogamente temos a informação digital que penetra nos mais diversos produtos tecnológicos da pós-modernidade como notebooks, tablets, smarthphones, painéis digitais, televisão digital, outdoor digital, entre outros. Dependendo das características do dispositivo e da capacidade de seus ambientes de informação se moldarem ao contexto e à informação, os sujeitos poderão utilizar melhor a informação digital, fazendo pontes entre esses dispositivos e seus ambientes, mas também poderão não conseguir utilizar dispositivos não responsivos, assim como a água pode não penetrar objetos com maior grau de compactação e dureza (Oliveira, 2014).

Pelo que foi exposto, percebemos que a ideia de pervasivo engloba a ideia de ubíquo quando nos referimos à informação, e a ideia de responsivo se refere, na metáfora supracitada, às tecnologias. Em nosso entendimento, pervasivo é uma categoria mais ampla e por isso foi adotada neste estudo. 
Uma Arquitetura da Informação Pervasiva é capaz de integrar espaços, ambientes, pessoas e tecnologias de forma transparente e holística. A Arquitetura da Informação Pervasiva deve utilizar os aparatos tecnológicos de modo que se tornem invisíveis numa ecologia informacional.

O estabelecimento teórico e conceitual da Arquitetura da Informação Pervasiva está vinculado ao seu status científico. No entendimento de Oliveira (2014), a Arquitetura da Informação Pervasiva se encontra num estado de emergência que fragiliza qualquer laboração teórica e epistêmica que lhe forneça uma identidade científica autônoma, própria ou desvinculada, ao contrário, só faz sentido delinear o status científico da Arquitetura da Informação Pervasiva percebendo-a no interior da história da Arquitetura da Informação. Nesse sentido, parece ser razoável afirmar que, a partir das demandas informacionais e tecnológicas que surgem após os anos 2000, a Arquitetura da Informação Pervasiva desponta como uma abordagem vinculada à Arquitetura da Informação que goza do status de disciplina científica pós-moderna.

A Arquitetura da Informação Pervasiva se expande em meio às outras abordagens da Arquitetura da Informação, questionando a validade dessas abordagens diante dass demandas informacionais e tecnológicas que exigem a pesquisa científica e o projeto de ecologias informacionais com uma arquitetura baseada na complexidade, no holismo e na integração de espaços, ambientes, tecnologias, canais e comportamentos dos sujeitos. É delineada como abordagem teórico-prática de uma disciplina científica pós-moderna.

Na visão de Resmini e Rosati (2011) não se trata de uma ingênua ou proposital ampliação do escopo dos arquitetos da informação com novos temas e áreas quentes, mas de uma mudança de perspectiva e evolução para racionalizar os processos tecnológicos para além da web. Trata-se de deslocar os estudos e as práticas em Arquitetura da Informação para estruturar os processos, avançando um passo na escada de abstração, em que a Arquitetura da Informação é menos de um conjunto específico de ferramentas e mais de um projeto conector entre os canais e os contextos. 


\section{O indispensável na Arquitetura da Informação Pervasiva}

A visão de Resmini e Rosati (2011) sobre a Arquitetura da Informação Pervasiva se concretiza por meio de heurísticas que são o resultado dos anos de prática profissional e acadêmica desses autores, no campo Arquitetura da Informação. Reconhecemos que contribuem sobretudo para sinalizar um conjunto de boas práticas em Arquitetura da Informação Pervasiva. Todavia, Oliveira (2014) justifica que as heurísticas de Resmini e Rosati (2011) merecem ser ampliadas e utiliza o trato fenomenológico-sistêmico para produzir a construção teórica e conceitual sobre Arquitetura da Informação Pervasiva, na perspectiva da Ciência da Informação, o que inclui as heurísticas de Resmini e Rosati (2011).

A pervasividade é um elemento conceitual indispensável para se compreender e conceituar a Arquitetura da Informação Pervasiva. Araújo (2003) ressalta que o termo "pervasivo" não existe no vocabulário português e sugere que seja compreendido como uma tradução para o termo em inglês: pervasive, que tem em sua raiz o componente latino pervasus, que significa avançar, penetrar, estender-se, alastrar, invadir.

De forma ampla, podemos dizer que o termo pervasividade trata da capacidade ou tendência a propagação, infiltração, difusão total ou parcial através de vários meios, canais, sistemas, tecnologias etc. (Aulete, 2013).

Na computação, os termos pervasividade e ubiquidade têm sido usados em recorrentes contextos como equivalentes, fazendo referência ao ramo da computação ubíqua ou pervasiva (Ark; Selker, 1999). Nesse sentido, a computação pervasiva ou ubíqua trataria da combinação de computadores com elementos como sensores isolados ou em rede, múltiplas interfaces presentes em objetos de todo e qualquer tipo como aparelhos, mobília e vestuário, distribuídos em diversos lugares (Jandl Jr., 2011).

No contexto da Arquitetura da Informação Pervasiva, defendemos que os termos pervasividade e ubiquidade têm semânticas diferentes e complementares, ambos fazem parte do processo ho- 
lístico de investigação e construção de ecologias informacionais complexas. Assim, discordamos da equivalência de significados entre pervasivo e ubíquo, frequentemente utilizada na computação.

Oliveira (2014) assegura que numa Arquitetura da Informação que trata de ecologias informacionais complexas, o termo pervasivo refere-se em primeiro lugar à informação e lhe fornece a qualidade de ser pervasiva, de ser penetrante, de ser extensível, de alastrar-se nos espaços, ambientes, dispositivos tecnológicos da ecologia e incorporar-se aos comportamentos dos sujeitos. Por conseguinte, também se torna qualidade dos espaços, dos ambientes e dos dispositivos tecnológicos da ecologia.

Por outro lado, a ubiquidade diz respeito à capacidade de estar presente em todos os lugares ao mesmo tempo, numa analogia mais ampla é sinônimo de onipresença (Houaiss; Villar, 2004). Enraíza-se etimologicamente no latim: ubiquitas, tendo ubique como componente que significa: que pode ter diversas localizações; que está ao mesmo tempo em toda parte; onipresente; que pode dividir-se ou existir em muitos pontos ao mesmo tempo; cuja projeção pode ser capturada de vários e diferentes lugares (Eckert-Hoff, 2011). Na mesma linha de pensamento, Abbagnano (2007, p.988) afirma numa perspectiva filosófica que a ubiquidade "[...] consiste em estar tudo em todo o espaço, e tudo em qualquer parte do espaço [...]”. A noção supracitada traz em suas entrelinhas a visão de ubiquidade sistêmica, útil para este trabalho, pois o "tudo em todo o espaço" pode ser compreendido como a informação (tudo) que permeia a ecologia (todo o espaço), nesta linha de raciocínio o "tudo em qualquer parte do espaço" faria alusão novamente à informação que está presente em cada parte da ecologia, ou seja, está nos espaços, está nos ambientes analógicos, digitais ou híbridos, está nas tecnologias e está nos comportamentos dos sujeitos. Essa noção incorpora as ideias de parte e todo, bem como as ideias de dinamismo do todo a partir do funcionamento integrado das partes, presentes na teoria geral dos sistemas de Bertalanffy (1975).

O termo ubiquidade tem sido largamente utilizado na computação para descrever os métodos de melhoramento para o uso de produtos computacionais, disponibilizando tais artefatos em 
ambientes físicos de forma que se tornem efetivamente invisíveis, transparentes, imperceptíveis aos sujeitos (Weiser, 1994, 1993).

Ponderando a ubiquidade, no contexto da computação ubíqua, vale destacar que a informação é processada em torno de nós, nos mais variados tipos de objetos e atividades diárias focando o uso e consumo da informação. Trata-se de uma visão orientada para o sistema que remete a conceitos como auto-organização, sistemas de informação complexos e abertos que estão presentes no que chamamos de ecologias informacionais complexas. De forma objetiva, podemos nos apoiar em Kuniavsky (2010) que compreende a ubiquidade como a práxis de marchetar o processamento de informação e comunicação em rede nos ambientes cotidianos para prover serviços, informação e comunicação.

Assim como a pervasividade, a noção de ubiquidade incorporada à Arquitetura da Informação Pervasiva é, em primeiro plano, característica da informação e, por consequência, dos espaços, dos ambientes e das tecnologias componentes de ecologia informacional complexa. Atua de modo que a informação e os produtos tecnológicos se incorporem à ecologia de maneira transparente. Implementar ubiquidade em uma ecologia informacional complexa significa investigar e reprojetar essa ecologia numa perspectiva de transparência e do escondimento de aparatos tecnológicos nos espaços e ambientes de informação.

As reflexões sobre ubiquidade remetem à ideia de convergência. Nesse sentido, trazemos as contribuições de Adam Greenfield sobre everyware. A noção de everyware, na perspectiva de Greenfield (2006) nos parece indispensável à Arquitetura da Informação Pervasiva. Trata-se de um enquadramento teórico que tenta explicar uma tendência, um fenômeno geral de convergência apoiada pela computação móvel e ubíqua. O pressuposto básico de Adam Greenfield (2006) é que o processamento da informação está se dissolvendo em meio aos comportamentos dos sujeitos. Suas observações sobre everyware são construídas utilizando heurísticas com enunciados breves que destacam características do everyware.

Entre cerca de 81 heurísticas, Resmini e Rosati (2011) destacam sete heurísticas de Greenfield sobre everyware como importantes 
para compreender a dimensão de convergência que é incorporada à Arquitetura da Informação Pervasiva. O Quadro 2 apresenta as sete heurísticas destacadas por Resmini e Rosati (2011).

Quadro 2 - Fragmentos das heurísticas de Grenfield

\begin{tabular}{|l|l|}
\hline Heurística ou Tese 21 & $\begin{array}{l}\text { Everyware recombina práticas e tecnologias de modo a } \\
\text { torná-las maiores do que a soma de suas partes. }\end{array}$ \\
\hline Heurística ou Tese 22 & Everyware é relacional. \\
\hline Heurística ou Tese 31 & $\begin{array}{l}\text { Everywareé uma estratégia para a redução da sobrecarga } \\
\text { cognitiva. }\end{array}$ \\
\hline Heurística ou Tese 40 & $\begin{array}{l}\text { O discurso de uniformidade anula ou suprime } \\
\text { distinções significativas entre os sistemas. }\end{array}$ \\
\hline Heurística ou Tese 41 & $\begin{array}{l}\text { Antes de serem unidos, os sistemas que compreendem } \\
\text { everyware podem parecer convencionais e com } \\
\text { interfaces e atributos de uso bem compreendidos. } \\
\text { Quando interligados, eles vão certamente interagir de } \\
\text { formas emergentes e imprevisíveis. }\end{array}$ \\
\hline Heurística ou Tese 47 & $\begin{array}{l}\text { A prática do desenvolvimento tecnológico tende a } \\
\text { tornar-se mais descentralizada. }\end{array}$ \\
\hline Heurística ou Tese 49 & $\begin{array}{l}\text { A prática do desenvolvimento tecnológico tende a } \\
\text { tornar-se mais descentralizada. }\end{array}$ \\
\hline
\end{tabular}

Fonte: Greenfield (2006, tradução nossa)

Os elementos heurísticos apresentados respondem adequadamente à convergência demandada pela Arquitetura da Informação Pervasiva. Trata-se de sistemas complexos integrados holisticamente, que se tornam maiores que a soma de suas partes e dependem fortemente dos relacionamentos entre as partes. A correlação é o indicador heurístico que aborda essa qualidade, implicando práticas de Arquitetura da Informação Pervasiva sujeitas à evolução contínua, gerando sistemas imprevisíveis, inacabados, abertos e dinâmicos em função das ações dos sujeitos, dos fluxos e dos diversos contextos (Resmini; Rosati, 2011).

A noção de everyware é relevante para a Arquitetura da Informação Pervasiva, pois traz o contributo teórico da convergência na ecologia informacional complexa que tem, entre seus componentes, os dispositivos de computação móvel. 
Essencial à Arquitetura da Informação Pervasiva, o place-making é uma das heurísticas de Resmini e Rosati (2011). Tais autores o denominam como senso de localização, diz respeito à capacidade da Arquitetura da Informação Pervasiva de ajudar os usuários na redução da desorientação, construindo, assim, um sentido de localização e aumentando a legibilidade por meio de um conjunto de pistas em ambientes digitais, analógicos e cross-channel. A compreensão de place-making não depende de avanços tecnológicos, mas da compreensão dos mecanismos cognitivos e psicológicos básicos que orientam a forma como experimentamos o mundo a partir da nossa existência (Resmini; Rosati, 2011).

O senso de orientação interliga-se conceitualmente às noções de espaço, lugar e contexto. Em primeiro lugar, é necessário diferenciar espaço e lugar, pois a noção de espaço se funda em elementos físicos, objetivos, impessoais e estáveis. Um lugar se estrutura em camadas e incorpora características psicológicas, subjetivas, experimentais, dinâmicas e existenciais. "Lugar é o que nós projetamos num espaço de informação [...]” (Resmini; Rosati, 2011, p.77) - é o que nós chamamos neste livro de ambientes.

A noção de contexto é mais ampla que o conjunto de configurações e restrições de um projeto. Em um processo pervasivo, o contexto é espacial, dinâmico e se modifica de acordo com os sujeitos, com o ambiente, com o tempo e com o espaço (Resmini; Rosati, 2011). O contexto na Arquitetura da Informação Pervasiva é necessariamente múltiplo, fluido, flexível, mutável e complexo. Não faz sentido dizer que uma ecologia informacional complexa possui um contexto, pois nela reside um conjunto de contextos que interliga os sujeitos às partes da ecologia e que se modificam ao longo do processo ecológico (Oliveira, 2014).

A Arquitetura da Informação Pervasiva deve promover a construção de lugares que permitam experiências contextuais, dinâmicas e semânticas por meio dos diversos caminhos, bordas, nós, marcos e zonas. Assim o place-making deve ser implantado interna e externamente, permitindo que os sujeitos estejam orientados em um único canal ou artefato da ecologia (place-making interno) ou, 
ainda, experimentando a recordação e a continuidade em todas as partes da ecologia (place-making externo) (Resmini; Rosati, 2011).

Oliveira (2014) afirma que se olharmos para os sistemas de navegação e rotulagem de Morville e Rosenfeld (2006), encontraremos consonâncias com o place-making na Arquitetura da Informação Pervasiva. Na abordagem sistêmica/informacional de Morville e Rosenfeld (2006) a combinação entre os sistemas possibilita que o sujeito mantenha-se localizado dentro do ambiente de informação digital, sendo possível responder as questões: Onde estou? Para onde posso ir? Como retornar?

$\mathrm{Na}$ Arquitetura da Informação Pervasiva, a complexidade que articula espaços, ambientes e produtos tecnológicos imprime a necessidade de ampliar a visão rotulagem/navegação para considerar com maior atenção as questões comportamentais e cognitivas dos sujeitos. O deslocamento e a localização na ecologia serão mantidos de forma satisfatória se no projeto da ecologia forem considerados os mecanismos de funcionamento cognitivo que dão aos sujeitos o senso de localização no mundo físico.

O place-making traz à investigação e aos projetos em Arquitetura da Informação Pervasiva a dimensão cognitivo-comportamental dos sujeitos da ecologia, potencializando o diálogo com a psicologia cognitiva e comportamental e com a filosofia da mente (Oliveira, 2014).

A consistência também é uma heurística apresentada por Resmini e Rosati (2011) e diz respeito à capacidade da Arquitetura da Informação Pervasiva de atender às finalidades, aos contextos e aos sujeitos definidos no projeto de uma ecologia informacional complexa e manter a mesma lógica ao longo do uso de diferentes mídias e ambientes em diversos momentos em que os sujeitos atuam (Resmini; Rosati, 2011).

Os elementos empíricos são importantes para avaliar a consistência: seu contexto, seus objetivos, seus usuários e o clima cultural que o produziu. Na Arquitetura da Informação Pervasiva, a consistência tem duas facetas: uma é interna e tem a ver com a relevância geral do sistema; a outra é externa e refere-se a qualquer artefato 
dentro da ecologia, considerando a ecologia como um todo (Resmini; Rosati, 2011, p.107).

Na Arquitetura da Informação Pervasiva, a consistência está diretamente ligada aos processos de categorização e classificação e às taxonomias. Resmini e Rosati (2011) sugerem:

- o uso de abordagem de protótipo gradual, para superar a falta de fronteiras claras entre categorias da ecologia (os protótipos funcionam como elementos centrais ou intermediários);

- o uso de um modelo up-and-down, pois o processo de classificação é iniciado no meio, a partir das categorias prototípicas, agrupando-as em supercategorias e, em seguida, dividindo-os em subordinados, categorias mais específicas;

- o uso de categorias de base para fácil acesso, pois os usuários devem ser capazes de chegar a categorias de nível básico, o mais rapidamente possível.

A heurística de consistência dialoga com os sistemas de rotulagem e sistemas de representação - metadados, tesauros e vocabulários controlados - previstos por Morville e Rosenfeld (2006). Na obra supracitada, a rotulagem e a adoção de estratégias para representação da informação impactam diretamente a navegação e a recuperação da informação em um ambiente de informação digital. Transcendendo esse ponto de vista, na Arquitetura da Informação Pervasiva a consistência é a responsável pela manutenção do fio lógico linguístico que, por meio de categorizações adequadas, manterão a ecologia navegável em seus espaços, ambientes e produtos tecnológicos (Oliveira, 2014).

A resiliência é uma heurística que está relacionada à capacidade de a Arquitetura da Informação Pervasiva moldar-se e adaptar-se aos usuários específicos - que constituem necessidades também específicas e estratégias de buscas contextuais. Ela permite que um espaço de informação se adapte à evolução das necessidades de seus usuários em diferentes contextos de uso, lugares e tempos, e também possibilita múltiplas estratégias de busca por informação, inclusive nos processos de escrita e reescrita da informação (Resmini; Rosati, 2011). 
A resiliência pode ser viabilizada a partir da integração entre padrões botton-up e padrões top-down. Sugere-se executar coleta, filtragem e reutilização dos rastros deixados pelos usuários na ecologia (Resmini; Rosati, 2011).

Conforme salientamos ao apresentar o place-making, os lugares informacionais têm um componente espacial e um componente existencial, emocional, pessoal e social, que se estende para trás e para a frente, para o passado e para o futuro. Explorando esses sedimentos, essas narrativas, as ecologias informacionais complexas podem se tornar resilientes (Resmini; Rosati, 2011, p.125).

Investigar, delinear uma investigação ou projetar uma ecologia informacional complexa e resiliente significa concebê-la com capacidade de adaptação e flexibilidade suficientes para suportar diferentes estratégias de busca direcionadas e não direcionadas, ativas e passivas, dando-lhe impulso para injetar um nível suficiente de serendipidade, e tornando-a capaz de reestruturar-se de acordo com as mudanças, interações heterogêneas, ações e necessidades de seus usuários, considerados sujeitos biológicos, culturais e sociais (Resmini; Rosati, 2011, p.127).

A execução de ciclos de operações simples, como monitoramento, filtragem e reutilização dos rastros deixados na ecologia, pode fornecer os fundamentos e possíveis entendimentos sobre como a resiliência pode ser construída. O cotidiano fornece nossas interações com pessoas, lugares, objetos e informações, produzindo uma grande quantidade de dados (Resmini; Rosati, 2011).

Tratamos na resiliência de algo mais complexo que a recuperação da informação em função das necessidades de informações de sujeitos que utilizam um sistema de busca previsto por Morville e Rosenfeld (2006). Trata-se de tornar o desenho ecológico capaz de se adaptar responsivamente para fornecer experiências de encontrabilidade da informação, o que inclui o encontro ao acaso, sem compromisso, desvinculado de uma necessidade de informação expressa de forma sintática a um sistema de busca.

Como heurística de Resmini e Rosati, a redução diz respeito à capacidade de gerenciar grandes conjuntos de informações e mini- 
mizar o estresse e a frustração associada com a escolha de um conjunto cada vez maior de fontes de informação, serviços e produtos (Resmini; Rosati, 2011).

Na visão de Oliveira (2014), o cerne da questão não é reduzir o número de opções disponíveis, mas, considerando a ecologia informacional complexa, a qualidade do processo que interliga as opções e as apresenta aos sujeitos, permitir que possam tirar o máximo proveito delas. Nesse sentido, dois conceitos interagem em complementaridade no processo de redução: complexidade e simplicidade. Simplicidade e complexidade não são mutuamente excludentes. Complexidade é riqueza, e simplicidade é uma estratégia para tornar essa complexidade viável, compreensível. Como tal, são complementares e alteram positivamente o equilíbrio do processo de projeto (Resmini; Rosati, 2011).

A redução pode ser viabilizada em uma Arquitetura da Informação Pervasiva por meio de dois princípios estruturais e organizacionais:

- organize and cluster, ou seja, organização e agrupamento;

- focus and magnify, que significam foco e ampliação.

O Quadro 3 apresenta uma síntese desses princípios.

Quadro 3 - Síntese dos princípios de redução em uma AIP

\begin{tabular}{|l|l|}
\hline $\begin{array}{l}\text { Organize and } \begin{array}{l}\text { cluster (organização } \\
\text { e agrupamento) }\end{array} \\
\text { autoevidentes para que usuários possam agrupar itens, } \\
\text { conforme a Lei de Hick. }{ }^{1}\end{array}$ & $\begin{array}{l}\text { Liste os itens de menu utilizando significados, regras } \\
\text { Quando nenhuma ordem é possível, agrupe e organize em }\end{array}$ \\
\cline { 2 - 2 } & $\begin{array}{l}\text { níveis. Níveis aninhados são uma possível estratégia de } \\
\text { projeto, porque uma estrutura larga não oferece nenhuma } \\
\text { vantagem sobre uma estrutura profunda, se a Lei de Hick } \\
\text { não se aplica. }\end{array}$ \\
\hline
\end{tabular}

Continua

1 Lei de Hick: time $=a+b \log 2(n+1)$. Demonstra que a escolha não é tanto um problemade quantidade, do número de opções disponíveis, mas, sim, da qualidade, da forma em que tais opções são organizadas e apresentadas ao sujeito. 
Focus and magnify (foco e ampliação)

\begin{abstract}
Contextualização e personalização são outras duas maneiras de combater o paradoxo da escolha. Inicialmente, deve-se concentrar em um nicho, um item, e então ampliar e olhar ao redor para itens semelhantes na mesma área. Embora os resultados finais sejam análogos aos obtidos por meio da aplicação do princípio organização e agrupamento, o princípio de foco e ampliação permite trabalhar na experiência do usuário, e é provavelmente mais adequado para ser aplicado para redução interna.
\end{abstract}

Fonte: Adaptado de Resmini e Rosati (2011).

Internamente, a redução está relacionada à forma como apresentamos as escolhas e opções em um único artefato da ecologia. Já a redução externa ocorre quando criamos estratégias para reduzir o estresse induzido pela busca da mesma forma em todos os canais diferentes. Nesse segundo sentido, mais amplo, a redução funciona em conjunto com a consistência (Resmini; Rosati, 2011).

A correlação é uma heurística que traduz as capacidades que a Arquitetura da Informação Pervasiva possui para sugerir conexões relevantes entre elementos de informação, serviços e bens, com o intuito de ajudar os sujeitos a alcançar objetivos explicitados ou estimular necessidades latentes. Na correlação, criam-se caminhos e possibilidades e um significado compartilhado para peças da ecologia. A correlação arrisca-se a introduzir no processo de projeto um eixo que enfatiza o valor de relações horizontais entre os itens: coordenação, similaridade e ligações semânticas (Resmini; Rosati, 2011).

Os espaços e ambientes de uma ecologia são palimpsestos, ou seja, são lugares onde as pessoas escrevem e reescrevem suas interações com outras pessoas e com objetos. A correlação conecta ambientes entrelaçados, sujeitos e objetos, fornecendo uma experiência de continuidade e descoberta em todas as partes da ecologia (Resmini; Rosati, 2011). A correlação pode ser:

- interna, ligando recursos pertencentes ao mesmo canal;

- externa, proeminente em arquiteturas da informação pervasiva, correlacionando recursos entre os canais (Resmini; Rosati, 2011, p.189). 
Para assegurar que na Arquitetura da Informação Pervasiva se efetue a correlação, Resmini e Rosati (2011) sugerem que o projeto se concentre apenas nas relações hierárquicas entre itens (pai-filho, parte de uma classe etc.), mas que também reforcem as relações horizontais, por vezes marcadas por similaridades implícitas entre os itens e pelo comportamento social. Os autores sugerem ainda que se reforce a serendipidade e a descoberta, usando a correlação para eliciar necessidades não expressas, necessidades que podem eclodir a partir de conexões inesperadas. $\mathrm{O}$ que pode ser feito ligando-se itens em todas as partes e não limitando o fluxo de informação para um canal de cada vez.

As ecologias informacionais são sistêmicas e complexas, um dos maiores desafios da Arquitetura da Informação Pervasiva é interoperar os blocos sistêmicos promovendo o funcionamento dinâmico e integrado da ecologia. Nesse sentido, a interoperabilidade torna-se uma categoria indispensável para que se racionalize e conceitue a Arquitetura da Informação Pervasiva (Oliveira, 2014).

Para o Online Dictionary for Library and Information Science (Odlis)

a interoperabilidade pode ser compreendida como a capacidade de um sistema de hardware ou software se comunicar e trabalhar efetivamente no intercâmbio de dados com outro sistema, geralmente de tipo diferente, projetado e produzido por um fornecedor diferente.

Sayão e Marcondes (2012) afirmam que na área de tecnologia da informação há certo consenso de que a interoperabilidade diz respeito à capacidade de computadores e softwares de fabricantes distintos trocarem informações. Numa ecologia informacional há bem mais que computadores e softwares, de modo que a interoperabilidade técnica necessita ser ampliada e compreendida como uma faceta da interoperabilidade. 
Assim, Sayão e Marcondes (2012) recorrem a Miller (2000) e Ukoln (2005) para facetar a interoperabilidade, conforme apresentado no Quadro 4.

Quadro 4 - Facetas de interoperabilidade

\begin{tabular}{|c|c|}
\hline $\begin{array}{c}\text { Faceta de } \\
\text { interoperabilidade }\end{array}$ & Descrição \\
\hline $\begin{array}{l}\text { Interoperabilidade } \\
\text { técnica }\end{array}$ & $\begin{array}{l}\text { As considerações sobre os aspectos técnicos incluem } \\
\text { assegurar envolvimento de um conjunto de organizações } \\
\text { no contínuo desenvolvimento de padrões de comunicação, } \\
\text { transporte, armazenamento e representação de } \\
\text { informações. } \\
\text { Inclui também os esforços cooperativos para assegurar que } \\
\text { padrões individuais evoluam em benefício da comunidade } \\
\text { envolvida e para facilitar, onde for possível, convergência } \\
\text { desses padrões, de forma que seja possível que os sistemas } \\
\text { possam ter como base mais de um conjunto de padrões. }\end{array}$ \\
\hline $\begin{array}{l}\text { Interoperabilidade } \\
\text { semântica }\end{array}$ & $\begin{array}{l}\text { Relacionada ao significado ou à semântica das } \\
\text { informações originadas de diferentes recursos e é } \\
\text { solucionada pela adoção de ferramentas comuns e/ } \\
\text { ou mapeáveis de representação da informação, como } \\
\text { esquemas de metadados, classificações, tesauros e } \\
\text { ontologias. }\end{array}$ \\
\hline $\begin{array}{l}\text { Interoper } \\
\text { política/1 }\end{array}$ & $\begin{array}{l}\text { Independentemente das questões relacionadas à maneira } \\
\text { pela qual a informação é descrita e disseminada, a decisão } \\
\text { de tornar os recursos informacionais mais amplamente } \\
\text { disponíveis e interoperáveis tem implicações para } \\
\text { a organização, para as equipes envolvidas e para os } \\
\text { usuários em termos comportamentais, de recursos e de } \\
\text { treinamento. }\end{array}$ \\
\hline $\begin{array}{l}\text { Interoperabilidade } \\
\text { intercomunitária }\end{array}$ & $\begin{array}{l}\text { Enfoca a necessidade, cada vez mais urgente, } \\
\text { impulsionada pela crescente interdisciplinaridade, } \\
\text { principalmente nas áreas de pesquisa, de acesso a } \\
\text { informações provenientes de um espectro amplo de fontes } \\
\text { distribuídas por organizações, áreas de conhecimento e } \\
\text { comunidades de natureza distintas. }\end{array}$ \\
\hline $\begin{array}{l}\text { Interoperabilidade } \\
\text { legal }\end{array}$ & $\begin{array}{l}\text { Considera as exigências e as implicações legais de tornar } \\
\text { livremente disponíveis itens de informação. }\end{array}$ \\
\hline $\begin{array}{l}\text { Interoperabilidade } \\
\text { internacional }\end{array}$ & $\begin{array}{l}\text { Quando se atua em escala internacional é necessário } \\
\text { contornar a diversidade de padrões e normas, os } \\
\text { problemas de comunicação, as barreiras linguísticas, as } \\
\text { diferenças no estilo de comunicação e na falta de uma } \\
\text { fundamentação comum. }\end{array}$ \\
\hline
\end{tabular}

Fonte: Sayão e Marcondes (2012). 
As facetas de interoperabilidade apresentadas no Quadro 4 possibilitam que a arquitetura de uma ecologia informacional complexa seja investigada e/ou projetada tendo como princípio o intercâmbio de dados e informações entre as partes da ecologia e com outras ecologias (Oliveira, 2014). A interoperabilidade técnica possibilitará a comunicação, o transporte, o armazenamento e a representação de informações em partes da ecologia, e ainda colabora com o processo de redução, pois permite o reaproveitamento dos estoques de dados e informações da ecologia. A interoperabilidade semântica é um elemento essencial e que complementa o processo de consistência, pois trata dos processos de significação na ecologia na medida em que se estabelecem critérios para representação da informação, para o uso de padrões de metadados, para as classificações e para o uso de taxonomias, tesauros e ontologias. $\mathrm{Na}$ interoperabilidade política/humana, as preocupações extrapolam as questões técnicas e se deslocam para os sujeitos e as equipes envolvidas no complexus ecológico, observando-os em termos comportamentais para gerar os recursos adequados.

O que Sayão e Marcondes (2012) tratam como interoperabilidade intercomunitária possibilita, na arquitetura da ecologia informacional complexa, o intercâmbio de dados e informações com outras ecologias. A interoperabilidade legal possibilita que o dinamismo ecológico ocorra sob a observância da legislação vigente que regula os contextos informacionais da ecologia. A interoperabilidade internacional atua quando a ecologia se estrutura em escala internacional, trata da diversidade de padrões e normas ou ainda da falta de padronização internacional, bem como dos problemas deriváveis da comunicação e das barreiras linguísticas.

Oliveira (2014) assegura que é irrefutável a presença efetiva dos sujeitos no uso, no aproveitamento, na construção e na reconstrução dos acúmulos informacionais nos diversos canais, dispositivos, espaços e ambientes, de modo que a reflexão sobre as questões semânticas se tornem capitais, sobretudo no âmbito da Arquitetura da Informação Pervasiva. Vale salientar que as questões semânticas estiveram presentes ao longo da história da Arquitetura da Infor- 
mação, principalmente no livro de Morville e Rosenfeld (2006), que utilizam redes semânticas para o delineamento:

- de contexto, conteúdos e comportamentos dos usuários;

- para dar suporte na sistematização da navegação, da organização, da busca, da rotulagem e da representação em um ambiente de informação digital.

Existem diversas possibilidades para se aparar conceitualmente o termo "semântica". Neste trabalho, pareceu-nos razoável a acepção que a compreende como subárea da semiótica e "[...] doutrina que considera as relações dos signos com os objetos a que eles se referem, que é a relação de designação [...]” (Abbagnano, 2007, p.869). Trata do processo de atribuição de significados, via linguagem, aos objetos e fenômenos que nos são apresentados como realidade, o que inclui todas as experiências informacionais e tecnológicas.

No campo tecnológico e na Ciência da Informação, a web semântica tem sido estudada como um conjunto de práticas que permitem a atribuição de significados automáticos por computador. Oliveira (2014) ressalta que a Arquitetura da Informação Pervasiva atua em experiências para além da web, mas isso não significa que exclua os artefatos e experiências web, de modo que a categoria web semântica é relevante na construção de uma acepção conceitual sobre a Arquitetura da Informação Pervasiva.

O termo web semântica foi apresentado pelo criador da web Tim Berners-Lee em uma publicação na revista Scientific American, que tratava de como novos formatos de conteúdo poderiam revolucionar o acesso web com a possibilidade de computadores interpretarem os dados. Sobre esse contexto, Ramalho, Vidotti e Fujita (2007) asseveram que:

[...] a partir do final da década de 1990, começaram a formalizar-se pesquisas relacionadas ao desenvolvimento de uma nova geração da web, com o objetivo de possibilitar a incorporação de ligações semânticas aos recursos informacionais, de modo que os próprios computadores possam "compreendê-las" de forma automatizada. Machine understandable information, com esta sucinta expressão 
Berners-Lee (1998) impulsionou os primeiros estudos em direção ao projeto da web semântica.

A web semântica tem sido articulada ao desenvolvimento de ambientes digitais dotados de interoperabilidade semântica a partir de padrões que orientam a estruturação de dados. Na visão do World Wide Web Consortium (W3C) o termo web semântica se refere à web dos dados linkados e oferece às pessoas a capacidade de criarem repositórios de dados na web, construírem vocabulários e escreverem regras para interoperarem com esses dados. A linkagem de dados é possível com tecnologias como RDF, SPARQL, OWL, SKOS.

A web semântica tem sido compreendida fazendo-se um contraponto com a web sintática. Nesse sentido, a web sintática diria respeito à geração de artefatos web que fazem apenas a apresentação da informação digital, deixando a cargo do sujeito cognoscente a ação de interpretar. A web sintática se desenvolveu como um mecanismo para troca de documentos entre pessoas, e não como um mecanismo que fomente a troca de dados e informações que pudessem ser processadas e interpretadas automaticamente (Breitman, 2005).

Ramalho, Vidotti e Fujita (2007) apontam que, desde seus primórdios, o projeto web semântica foi concebido como um conjunto de tecnologias relacionadas. Nesse cenário o W3C, que dispunha de Tim Berners-Lee entre seus empreendedores, contribuiu com a primeira proposta de arquitetura da web semântica vista como uma série de camadas sobrepostas, em que cada camada ou tecnologia deveria obrigatoriamente ser complementar e compatível com as camadas inferiores, ao mesmo tempo em que não deveria depender das camadas superiores, de modo a possibilitar uma estrutura idealmente escalonável, que indicasse os passos e as tecnologias fundamentais para a concretização do projeto web semântica (Ramalho; Vidotti; Fujita, 2007).

Sobre a web semântica, Santarém Segundo e Vidotti (2011) salientam que o conceito cunhado por Tim Berners-Lee e homologado pelo W3C tem sido objeto de estudo da Ciência da Informação e da computação. Também chamada de web 3.0, a web semântica consiste num conjunto de padrões que objetivam fazer com que o 
material publicado na web possa ser recuperado de forma semântica, agrupando informações com similaridade de significado, independentemente de sua estrutura sintática.

O que apresentamos sobre a web semântica é aplicável às partes da ecologia informacional complexa devotadas ao funcionamento via $w e b$, possibilitando que, no fluxo informacional, os materiais sejam recuperados de forma semântica e que se fomente uma organização ecológica em função da similaridade de significados e não apenas de sua estrutura sintática.

Uma ecologia informacional complexa deve ser acessível à diversidade de sujeitos e de grupos sociais que nela interagem. Ademais, os sujeitos e grupos são diferentes e possuem necessidades específicas que não podem se constituir como um entrave à sua ação na ecologia. Considerando ainda que uma ecologia informacional complexa pode reunir ambientes analógicos, digitais e híbridos, a acessibilidade é uma condição indispensável na Arquitetura da Informação Pervasiva (Oliveira, 2014).

O Decreto Federal n. 5.296/2004, em seu artigo $8^{\circ}$, I, situa:

I - acessibilidade: condição para utilização, com segurança e autonomia, total ou assistida, dos espaços, mobiliários e equipamentos urbanos, das edificações, dos serviços de transporte e dos dispositivos, sistemas e meios de comunicação e informação, por pessoa portadora de deficiência ou com mobilidade reduzida (Brasil, 2004, p.1).

Essa acepção deve ser considerada em uma investigação científica ou em um projeto da Arquitetura da Informação Pervasiva, pois, em função de sua abrangência, viabiliza a racionalização de soluções de computação ubíqua para facilitar a permanência de sujeitos com necessidades especiais na ecologia informacional complexa. A legislação vigente sobre acessibilidade impõe que os bens materiais e simbólicos usados coletivamente sejam destinados a todas as pessoas, o que inclui pessoas com necessidades especiais.

Como complemento, citamos a Convenção Internacional sobre os Direitos das Pessoas com Deficiência, adotada pela ONU em 2007 e 
que no Brasil foi incorporada por meio do Decreto Federal n. 6.949 de 25 de agosto de 2009, que estabelece o seguinte texto em seu artigo $9^{\circ}$ :

A fim de possibilitar às pessoas com deficiência viver com autonomia e participar plenamente de todos os aspectos da vida, os Estados Partes deverão tomar as medidas apropriadas para assegurar-lhes o acesso, em igualdade de oportunidades com as demais pessoas, ao meio físico, ao transporte, à informação e comunicação, inclusive aos sistemas e tecnologias da informação e comunicação, bem como a outros serviços e instalações abertos ou propiciados ao público, tanto na zona urbana como na rural. (Brasil, 2009, p.1, grifo nosso)

Ainda tratando da acessibilidade na web, destacamos as contribuições do W3C que, por meio do grupo de trabalho sobre acessibilidade, têm contextualizado o tema "acessibilidade na web" no cotidiano das pessoas e têm fomentado a discussão sobre as principais barreiras de acesso à web pelos diferentes grupos de usuários. O grupo supracitado também tem apresentado recomendações e diretrizes que podem ser usadas por desenvolvedores de aplicações e soluções web para evitar ou eliminar barreiras de acesso, tem indicado as respectivas fontes de consulta, orientado em relação aos procedimentos que devem ser adotados para avaliar a acessibilidade de um ambiente web e alertado os cidadãos e seus representantes sobre como devem proceder para cobrar a acessibilidade em websites (Brasil, 2005).

Oliveira (2014) reforça que as questões de acessibilidade na arquitetura de uma ecologia informacional complexa são indispensáveis e devem ser pensadas considerando o fluxo de informação nos espaços, ambientes e artefatos tecnológicos, vinculando-os aos comportamentos dos sujeitos da ecologia.

A usabilidade, categoria indispensável para se pensar na Arquitetura da Informação Pervasiva, possibilita que os artefatos informacionais e tecnológicos sejam mais bem utilizados pelos sujeitos da ecologia informacional complexa.

De forma abrangente, a usabilidade pode ser concebida como uma "[...] medida na qual um produto pode ser usado por usuários específicos para alcançar objetivos específicos com eficácia, eficiên- 
cia e satisfação em um contexto específico de uso [...]" (Associação Brasileira de Normas Técnicas, 2002, p.3). A partir desse conceito, podemos dizer que usabilidade está relacionada à capacidade apresentada pelos componentes da ecologia de possibilitar experiências informacionais e tecnológicas eficazes, eficientes e agradáveis.

O debate sobre a encontrabilidade ou findability está presente na obra de Morville e Rosenfeld (2006) que a compreendem como um fator crítico de sucesso para a usabilidade geral. Ressaltam, ainda, que em um ambiente de informação digital usuários devem encontrar o que precisam por meio de uma combinação de navegação, busca e perguntas, do contrário o ambiente se apresentará falho. A nosso ver, a assertiva de Morville e Rosenfeld (2006) sobre a encontrabilidade continua válida e pode ser aplicada aos artefatos da ecologia informacional complexa.

Ampliando a noção de encontrabilidade apresentada por Morville e Rosenfeld (2006), Vechiato (2013) elabora um conceito de encontrabilidade da informação que é pertinente para ser usado no âmbito da Arquitetura da Informação Pervasiva. Para Vechiato (2013, p.169) trata-se de "[...] elemento que se situa entre as funcionalidades de um ambiente informacional tradicional, digital ou híbrido e as características dos sujeitos [...]”.

Ainda acrescenta que a encontrabilidade da informação está relacionada

[...] aos processos que compõem o fluxo infocomunicacional, desde a produção até a apropriação da informação. Isso porque possibilita aos sujeitos o encontro da informação adequada às suas necessidades em uma determinada situação de busca, isto é, a partir da recuperação da informação por meio dos mecanismos de busca e/ ou por meio da navegação em arquiteturas da informação top-down e/ou bottom-up. (Vechiato, 2013, p.169)

A encontrabilidade considera a intencionalidade dos sujeitos nas interações durante o processo de comunicação que, inclusive, subsidia a elaboração técnica e de tecnologias para a organização e para a representação da informação (Vechiato, 2013). 
Apresentamos em seguida um quadro adaptado de Oliveira (2014), como síntese dos elementos indispensáveis à construção teórica sobre a Arquitetura da Informação Pervasiva.

Quadro 5 - Atributos da Arquitetura da Informação Pervasiva

\begin{tabular}{|c|c|c|}
\hline Atributo & Enunciado & $\begin{array}{c}\text { Autores } \\
\text { relevantes }\end{array}$ \\
\hline Status científico & $\begin{array}{l}\text { Abordagem teórica e prática da } \\
\text { Arquitetura da Informação enquanto } \\
\text { disciplina científica pós-moderna. }\end{array}$ & $\begin{array}{l}\text { Macedo (2005) } \\
\text { Albuquerque } \\
(2010) \\
\text { Albuquerque e } \\
\text { Lima-Marques } \\
(2011)\end{array}$ \\
\hline $\begin{array}{l}\text { Ecologia } \\
\text { informacional } \\
\text { complexa }\end{array}$ & $\begin{array}{l}\text { Objeto de investigação da Arquitetura } \\
\text { da Informação Pervasiva. Conjunto } \\
\text { de relações entrecruzadas de sujeitos, } \\
\text { processos, estruturas informacionais, } \\
\text { estruturas tecnológicas, espaços, } \\
\text { ambientes, canais, dispositivos e } \\
\text { quaisquer elementos pertencentes } \\
\text { aos ambientes analógicos, digitais } \\
\text { ou híbridos. Trançados por meio da } \\
\text { noção de complexidade de forma } \\
\text { interdependente, interativa as partes e o } \\
\text { todo, o todoe as partes, as partes entre si. }\end{array}$ & $\begin{array}{l}\text { Davenport (1998) } \\
\text { Morin (1998) } \\
\text { Oliveira (2014) }\end{array}$ \\
\hline Pervasividade & $\begin{array}{l}\text { Capacidade ou tendência que a } \\
\text { informação possui de propagar- } \\
\text { se, infiltrar-se, difundir-se total ou } \\
\text { inteiramente através de vários meios, } \\
\text { canais, sistemas, tecnologias etc. }\end{array}$ & Oliveira (2014) \\
\hline Ubiquidade & $\begin{array}{l}\text { Capacidade que a informação possui } \\
\text { de estar presente em todos os lugares ao } \\
\text { mesmo tempo. Espécie de onipresença } \\
\text { tecnológica. }\end{array}$ & $\begin{array}{l}\text { Eckert-Hoff (2011) } \\
\text { Abbagnanno (2007) }\end{array}$ \\
\hline Everyware & $\begin{array}{l}\text { Tendência, fenômeno geral de } \\
\text { convergência para o processamento } \\
\text { da informação dissolvida em meio aos } \\
\text { comportamentos dos sujeitos. }\end{array}$ & Greenfield (2006) \\
\hline Place-making & $\begin{array}{l}\text { Capacidade de redução da } \\
\text { desorientação, capacidade de } \\
\text { construção do sentido de localização na } \\
\text { ecologia informacional complexa. }\end{array}$ & $\begin{array}{l}\text { Resmini e Rosati } \\
\text { (2011) }\end{array}$ \\
\hline
\end{tabular}




\begin{tabular}{|c|c|c|}
\hline Consistência & $\begin{array}{l}\text { Capacidade de atender finalidades, } \\
\text { contextos e pessoas na ecologia } \\
\text { informacional complexa. }\end{array}$ & $\begin{array}{l}\text { Resmini e } \\
\text { Rosati (2011) }\end{array}$ \\
\hline Resiliência & $\begin{array}{l}\text { Capacidade de moldar-se e adaptar- } \\
\text { se a usuários específicos, necessidades } \\
\text { específicas e estratégias de busca } \\
\text { contextuais. }\end{array}$ & $\begin{array}{l}\text { Resmini e } \\
\text { Rosati (2011) }\end{array}$ \\
\hline Redução & $\begin{array}{l}\text { Capacidade de gerenciar grandes conjuntos } \\
\text { de informações e minimizar o estresse } \\
\text { e frustração associada à escolha de um } \\
\text { conjunto cada vez maior de fontes de } \\
\text { informação, serviços e produtos. }\end{array}$ & $\begin{array}{l}\text { Resmini e } \\
\text { Rosati (2011) }\end{array}$ \\
\hline Correlação & $\begin{array}{l}\text { Capacidade de sugerir conexões relevantes } \\
\text { entre elementos de informação, serviços e } \\
\text { bens para ajudar os usuários a alcançar } \\
\text { objetivos explicitados ou estimular } \\
\text { necessidades latentes. }\end{array}$ & $\begin{array}{l}\text { Resmini e } \\
\text { Rosati (2011) }\end{array}$ \\
\hline Interoperabilidade & $\begin{array}{l}\text { Capacidade de uma ecologia ou de partes } \\
\text { de uma ecologia se comunicar e trabalhar } \\
\text { efetivamente no intercâmbio de dados ou } \\
\text { informações com outra ecologia ou com } \\
\text { outra parte da ecologia, geralmente de tipo } \\
\text { diferente, projetada e produzida de forma } \\
\text { diferente. }\end{array}$ & $\begin{array}{l}\text { Sayão e } \\
\text { Marcondes } \\
(2012)\end{array}$ \\
\hline Semântica & $\begin{array}{l}\text { Processo de atribuição de significados, via } \\
\text { linguagem, aos objetos e fenômenos que } \\
\text { nos são apresentados como realidade. }\end{array}$ & $\begin{array}{l}\text { Abbagnano } \\
(2007)\end{array}$ \\
\hline Acessibilidade & $\begin{array}{l}\text { Possibilidade e condição de alcance, } \\
\text { percepção e entendimento para a utilização } \\
\text { com segurança e autonomia de edificações, } \\
\text { espaços, mobiliários, equipamentos } \\
\text { urbanos e elementos tecnológicos. }\end{array}$ & $\begin{array}{l}\text { ABNT NBR } \\
9050 / 2004\end{array}$ \\
\hline Usabilidade & $\begin{array}{l}\text { Capacidade dos elementos da ecologia de } \\
\text { serem usados com eficiência, eficácia e } \\
\text { satisfação pelos sujeitos. }\end{array}$ & ISO (2002) \\
\hline Encontrabilidade & $\begin{array}{l}\text { Processo que se situa entre as } \\
\text { funcionalidades de um ambiente } \\
\text { informacional tradicional, digital ou } \\
\text { híbrido e as características dos sujeitos, } \\
\text { comporta desde a produção até a } \\
\text { apropriação da informação e possibilita a } \\
\text { recuperação da informação por meio dos } \\
\text { mecanismos de busca. }\end{array}$ & $\begin{array}{l}\text { Morvile e } \\
\text { Rosenfeld } \\
(2006) \\
\text { Vechiato } \\
(2013)\end{array}$ \\
\hline
\end{tabular}

Fonte: Adaptado de Oliveira (2014). 


\section{Modelo conceitual para Arquitetura da Informação Pervasiva}

Utilizando os aparatos teóricos da fenomenologia e do sistemismo, Oliveira (2014) articulou (no plano da linguagem) uma construção interpretativa (no plano ontológico) sobre a Arquitetura da Informação Pervasiva, sintetizada "[...] com poucas variáveis-fatores manejáveis, de tal sorte que as relações mais significativas possam ser identificadas e estudadas" (Martins; Teophilo, 2009, p.29).

O empreendimento teórico de Oliveira (2014) diferencia conceito e significado com base no livro Pensar conceitos, de Jonh Wilson (2001). A distinção entre os termos conceito e significado, apesar de estarem estreitamente vinculados, é clara:

[... não há - rigorosamente falando - "o" significado de uma palavra, tampouco "o" conceito de um objeto. Quando falamos - numa espécie de linguagem taquigráfica - sobre "o" significado de uma palavra, nos referimos aos elementos significativos que aparecem nos numerosos e variados usos da palavra e que a tornam compreensível. Do mesmo modo, quando falamos sobre "o" conceito de um objeto, nos referimos quase sempre, abreviadamente, a todos os diferentes conceitos daquele objeto que os indivíduos tenham, na medida que todos coincidam. (Wilson, 2001, p.52)

Para Oliveira (2014), o uso que fazemos de uma palavra e a compreensão que temos dela têm relação com o conceito que temos de um objeto; trata-se de um fenômeno contextual que depende de referências que se estabelecem no espaço, no tempo e na cultura. Wilson (2001) reconhece que a atividade de especificação de um conceito tem alto grau de arbítrio, assim como toda e qualquer atividade de interpretação e categorização.

Um conceito pode ser considerado como um processo de significação dos objetos ou fenômenos por meio das palavras, estruturados de maneira lógica e psicológica (Wilson, 2001). Na formação 
de conceitos, os aspectos lógicos podem ser analisados do ponto de vista linguístico, pois " [...] o uso e o entendimento da linguagem servem, ao mesmo tempo, como guias para a formação de conceitos e como testes de conceitos já formados" (Wilson, 2001, p.35). Os aspectos psicológicos de um conceito trazem o componente subjetivo, inerente ao sujeito que cria ou interpreta ou, ainda, interpreta quando cria, fazendo-o com base na sua história, cultura e contextos espaçotemporais (Oliveira, 2014).

Para Deleuze e Guattari (2004) não existe um conceito simples ou composto por um só componente - todo conceito tem componentes que o define, de modo que cada conceito é uma multiplicidade de afirmações.

Nessa linha teórica e analítica de construção conceitual, a pesquisadora alemã Dahlberg (1978) compreende que "[...] o conceito é constituído de elementos que se articulam numa unidade estruturada [...]" e abrange "[...] o conceito como a compilação de enunciados sobre determinado objeto, fixada por um símbolo linguístico [...]" (Dahlberg, 1978, p.102). Para a autora a construção de um conceito necessita de um rol de enunciados e uma ação de compilação/fixação desses enunciados de forma discursiva. Tal embasamento apresentou-se adequado para Oliveira (2014) elaborar uma construção conceitual para Arquitetura da Informação Pervasiva a partir da compilação dos enunciados obtidos no exercício fenomenológico de captura das essências (ver Quadro 5).

O conceito de Arquitetura da Informação Pervasiva elaborado por Oliveira (2014) articula discursivamente quatro princípios básicos que respondem sobre o status científico da Arquitetura da Informação Pervasiva, seu objeto de investigação, sua efetiva contribuição e sua materialidade. A Arquitetura da Informação Pervasiva pode ser compreendida a partir da seguinte modelagem conceitual

[...] uma abordagem teórico-prática da disciplina científica pós-moderna Arquitetura da Informação, trata da pesquisa científica e do projeto de ecologias informacionais complexas. Busca man- 
ter o senso de localização do usuário na ecologia e o uso de espaços, ambientes e tecnologias de forma convergente e consistente. Promove a adaptação da ecologia a usuários e aos novos contextos, sugerindo conexões no interior da ecologia e com outras ecologias. Facilita a interação com conjuntos de dados e informações ao considerar os padrões interoperáveis, a acessibilidade, a usabilidade, as qualidades semânticas e a encontrabilidade da informação, portanto deve buscar bases na Ciência da Informação. (Oliveira, 2014, p.166)

Em consonância com a modelagem conceitual supracitada, a Figura 7 ilustra que a Arquitetura da Informação Pervasiva tem, na atualidade, o status de abordagem teórica e prática, vinculada à Arquitetura da Informação enquanto disciplina científica pós-moderna. Quando indagamos do que trata a Arquitetura da Informação Pervasiva, fica claro que seu objeto ou fenômeno de investigação são as ecologias informacionais complexas, que integram e articulam de forma holística espaços, ambientes, tecnologias, artefatos tecnológicos e sujeitos. Conforme visto na Figura 7, a Arquitetura da Informação Pervasiva possibilita a realização de investigações científicas e/ou projetos de ecologias informacionais complexas que busquem:

- manter os sujeitos orientados dentro da ecologia;

- o funcionamento convergente das partes da ecologia e de seu todo em relação a outras ecologias;

- a adaptabilidade da partes da ecologia aos novos contextos e aos comportamentos dos sujeitos;

- a interoperabilidade; a atenção às questões semânticas, de acessibilidade, de usabilidade e de encontrabilidade. 


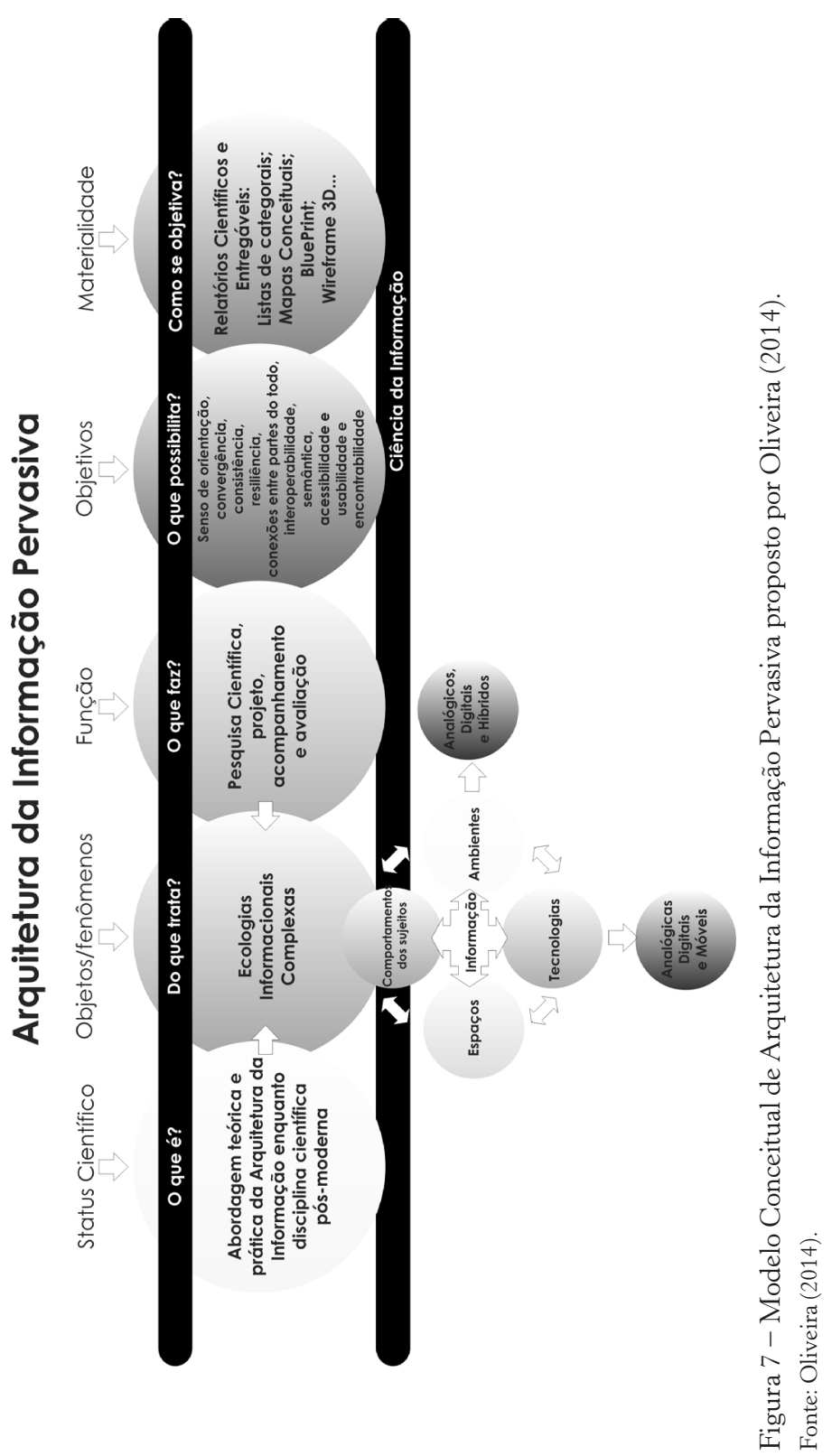


A Figura 7 sinaliza que a Arquitetura da Informação Pervasiva se materializa por meio de produtos científicos (relatórios de pesquisa, artigos em periódicos, textos completos em anais de congressos, livros, capítulos de livros, monografias, trabalhos de conclusão de curso, dissertações, teses, entre outros) e ainda por meio de entregáveis. Os entregáveis têm sido utilizados ao longo da história da Arquitetura da Informação e podem ser compreendidos como representações das etapas do processo de projeto ou avaliação em AI; são racionalizações expressas sob a forma de listas de categorias, mapas conceituais, vocabulários controlados, blueprints, padrões de metadados e wireframes 2D e 3D. Destacamos ainda a barra que faz a Ciência da Informação interceptar os elementos conceituais indicando que o processo de construção conceitual foi realizado no interior da Ciência da Informação e reforçando nosso argumento de que a pervasividade é uma característica da informação que é objeto da CI.

\section{Reflexões hipotéticas sobre uma livraria pervasiva}

Com o objetivo de incitar a imaginação dos leitores para refletir sobre as ecologias informacionais complexas e sobre o conceito de Arquitetura da Informação Pervasiva, apresentamos a seguir um contexto hipotético, sob a forma de narrativa, do que chamamos de experiência pervasiva em uma ecologia informacional complexa. Trata-se de uma situação imaginada, na qual utilizamos nomes e lugares fictícios.

Miguel é um ávido leitor e viu, num comercial de TV, que foi lançada uma nova biografia sobre Albert Eisntein, o que o deixou bastante interessado.

Rapidamente, Miguel abre seu notebook para realizar uma pesquisa na internet e identificar as livrarias que já disponibilizam a nova obra. Embora Miguel seja muito ligado aos avanços da técnica e da tecnologia - razão pela qual possui computador de mesa, notebook, tablet e smatphone -, não dispensa a leitura de um livro em papel. 
Por meio de um site de buscas, ele encontra a obra disponível para compra em quatro livrarias, em suporte papel e em formato digital para leitura em dispositivos móveis. Em três livrarias é possível fazer a compra online. Miguel escolhe a Livraria Information que apresentou o menor preço para o livro, tanto no suporte papel quanto em formato digital. A navegação no site da Livraria Information pode ser realizada com ou sem identificação do usuário, Miguel prefere acatar a sugestão do site e identifica-se para usufruir das potencialidades deste ambiente de informação digital.

Assim, ele encontra a obra que está interessado, mas também navega em outros títulos que lhe foram sugeridos enquanto paginava as camadas do site. Durante a experiência de navegação, recebe um convite da Livraria Information para que visite a loja física e realize gratuitamente uma experiência de leitura interativa. Intrigado com o convite, Miguel decide aceitá-lo e informa no site que comparecerá à livraria.

O trajeto de táxi para a Livraria Information foi tranquilo. Miguel pôde olhar a paisagem da cidade, ver os Ipês amarelos derramando um tapete que muda o colorido das ruas. Miguel chega à Livraria Information, paga o taxista e, na entrada da livraria, dirige-se a uma funcionária da recepção e informa que veio participar de uma tal "leitura interativa". A atendente entra no sistema de informações e resgata os dados de Miguel, solicitando a ele que espere alguns minutos, pois logo será levado para o ambiente de leitura interativa.

Uma segunda atendente, Marília, conduz Miguel pela livraria, mostrando todos os espaços e explicando que a empresa tem modificado sua arquitetura e a arquitetura de seus ambientes digitais para propiciar uma experiência pervasiva aos clientes. Salienta ainda que o ambiente de leitura interativa faz parte dessa rearquitetura.

Os dois chegam ao ambiente de leitura interativa - uma sala composta por células de leitura com cadeiras confortáveis, luminárias e uma mesa de apoio. Marília informa a Miguel que a célula de 
leitura 8 foi preparada especialmente para ele e lhe deseja uma boa experiência de leitura.

Conforme orientação de Marília, Miguel se dirige à célula 8 e encontra em cima da mesa de apoio o livro em papel com a nova biografia de Albert Einstein, um tablet, um smartphone e outros títulos em papel escolhidos com base na navegação que Miguel realizou quando estava em casa, logado no site da Livraria Information.

Ansioso, ele pega o livro em papel e se acomoda na cadeira reclinável. Nesse momento, sem que aperte nenhum botão, percebe que o estofamento da cadeira ajusta-se ao seu corpo aumentando o nível de conforto, percebe também que e luminária ajusta a iluminação dirigida para favorecer a leitura.

Miguel folheia o livro, lê o prefácio e começa a degustar o primeiro capítulo, quando percebe que há na cadeira um device com tela sensível ao toque e que pode ser usado para pedir cafés.

Um café espresso curto é escolhido por Miguel.

Enquanto o café chega ele abre o tablet e na tela um App da Livraria Inspiration lhe solicita login e senha.

Logado no tablet, Miguel navega no App que se parece com o ambiente físico da livraria, tem cores e layout semelhantes. Ele tem a sensação de que já havia usado aquele App, quando conclui que tal familiaridade tinha a ver com o momento que Marília lhe apresentou a livraria, mostrando todos os espaços e produtos nela distribuídos.

Concentrado na leitura no tablet, Miguel percebe pelo aroma de café que uma funcionária da lanchonete estava a postos com o seu café. Miguel degusta-o lentamente. O grão de sabor forte e encorpado lembra os vários cafés que Miguel tomou em viagens pelo mundo.

Após algum tempo, o device que ficava meio escondido, meio transparente na cadeira solicita que Miguel avalie o café espresso utilizando uma escala de 0 a 10 . O café recebe nota 9 e o device pergunta se Miguel deseja outro café, oferecendo uma opção mais suave e uma opção mais encorpada. Ele escolhe a opção mais encorpada e se anima para tomar um segundo café. 
No tablet, Miguel recebe a informação de que os cafés estão disponíveis para venda na lanchonete da livraria. Ele rapidamente fica interessado em levar para casa o café que experimentou.

Lê mais um pouco no tablet e decide usar o smartphone, que estava sobre a mesa. Loga-se e percebe que o App no smartphone o levou para a mesma página do mesmo livro que lia no tablet. Ele está encantado com essa tal de experiência pervasiva.

Miguel dirige-se à lanchonete e pega dois pacotes de café, em seguida compra a nova biografia de Albert Einstein em papel e a versão digital para leitura em seus dispositivos móveis. Depois de ter pago decide ouvir um pouco de música na seção Music\&Cinema. Por meio de um toten, ele aprecia a voz forte, a musicalidade da cantora Donna. No próprio toten, Miguel compra três faixas do último disco de Donna e já sai ouvindo no seu smartphone.

Ele retorna à sua casa e, nas redes sociais da Livraria Information, faz elogios, agradece o atendimento e fala de como foi boa essa tal de experiência pervasiva. 


\section{REFERÊNCIAS}

ABBAGnanO, N. Dicionário de Filosofia. 5.ed. São Paulo: Martins Fontes, 2007.

AGAZZI, E. El impacto epistemológico de la tecnología. Génova: Universidad Génova, 1997. Disponível em: <http://www.argumentos.us.es/ numero1/agazzi.htm> Acesso em: 25 ago. 2012.

ALBUQUERQUE, A.R.R. Discurso sobre fundamentos de Arquitetura da Informação. 2010. 241 f. Tese (Doutorado em Ciência da Informação) - Faculdade de Ciência da Informação. Universidade de Brasília, Brasília, 2010.

ALBUQUERQUE, A.R.R.; LIMA-MARQUES, M. Sobre os fundamentos da Arquitetura da Informação. Perspectivas em Gestão $\mathcal{E}$ Conhecimento, João Pessoa, v. 1, p.60-72, 2011.

AMDAHL, Gene M.; BLAAUW, Gerrit A.; BROOKS, F. P. Architecture of the IBM System/360. IBM Journal of Research and Development, v. 8, n. 2, p.87-101, 1964. Disponível em: <http://ieeexplore. ieee.org/stamp/stamp.jsp?tp=\&arnumber $=5392210>$ Acesso em: 27 mar 2013.

ARAÚJO, R.B. Computação ubíqua: Princípios, tecnologias e desafios. In: XXI Simpósio Brasileiro de Redes de Computadores, 21., 2003, Natal. Anais... . Natal: UFRN, 2013. v. 1, p.11-3.

ARK, Wendy S., TED Selker. A look at human interaction with pervasive computers. IBM Systems Journal, v.38, n.4, p.504-7, 1999.

ARTIGAS, J.B.V. Caminhos da arquitetura. São Paulo: Lech, 1981. 


\section{ASSOCIAÇÃO BRASILEIRA DE NORMAS TÉCNICAS. NBR}

9241-11: requisitos ergonômicos para trabalho de escritório com computador - Parte 11 - orientações sobre usabilidade. Rio de Janeiro: ABNT, 2002.

AULETE, C. Aulete Digital - Dicionário contemporâneo da Língua Portuguesa. Disponível em: <http://aulete.uol.com.br>. Acesso em: 30 jan. 2014.

BAUMAN, Z. Ética pós-moderna. São Paulo: Paulus, 1997. Modernidade líquida. Rio de Janeiro: Zahar, 2003.

BELL, D. O advento da sociedade pós-industrial. São Paulo: Cultrix, 1973.

BORKO, H. Information science: what is it? American Documentation, v.19, n. 1, 1968.

BRANCHEAU, J.C.; SCHUSTER, L.; MARCH, S.T. Building and implementing an information architecture. ACM SIGMIS Database, v.20, n.2, p.9-17, 1989.

BRANCHEAU, J.C.; WETHERBE, J.C. Information architectures: methods and practice. Information Processing \& Management, v.22, n.6, p.453-63, 1986.

BRASIL. Arquivo Nacional. Dicionário brasileiro de terminologia arquivística. Rio de Janeiro: Arquivo Nacional, 2005.

BRASIL. Decreto n. 5.296, de 2 de dezembro de 2004. Regulamenta as Leis n. 10.048, de 8 de novembro de 2000, que dá prioridade de atendimento às pessoas que especifica, e a n. 10.098, de 19 de dezembro de 2000, que estabelece normas gerais e critérios básicos para a promoção da acessibilidade das pessoas portadoras de deficiência ou com mobilidade reduzida, e dá outras providências. 2004. Disponível em: <http://www.planalto.gov.br/ccivil_03/_Ato2004-2006/2004/ Decreto/D5296.htm>. Acesso em: 26 jan. 2014.

BRASIL, 2005. Recomendações de Acessibilidade para Construção e Adaptação de Conteúdos do Governo Brasileiro na Internet: eMag, Acessibilidade de Governo Eletrônico. Cartilha Técnica. Departamento de Governo Eletrônico. Secretaria de Logística e Tecnologia da Informação. Ministério do Planejamento, Orçamento e Gestão. Versão 2.0. 14 de Dezembro de 2005. Disponível em: <https://www.governoeletronico.gov.br/acoes-e-projetos/e-MAG>. Acesso em: 15 abr. 2008.

BRASIL. Decreto n. 6.949, de 25 de agosto de 2009. Promulga a Convenção Internacional sobre os Direitos das Pessoas com Deficiência e seu Protocolo Facultativo. 2009. Disponível em: http://www.planalto. 
gov.br/ccivil_03/_Ato2007-2010/2009/Decreto/D6949.htm. Acesso em: 26 jan. 2014.

BREITMAN, K. Web Semântica: a internet do futuro. São Paulo: LTC, 2005.

BROOKES, B.C. The foundations of information science. Part. I. Philosophical aspects. Journal of Information Science, v.2, p.125-133, 1980.

BURDEN, E. Dicionário ilustrado de arquitetura. 2.ed. São Paulo: Bookman, 2006.

CALEGARE, M.G.A.;. SILVA JUNIOR, N.S. Inter e/ou transdiciplinariedade como condição de estudo de questões socioambientais. Interthesis, Florianópolis, v.9, n.2, jul./dez., 2012.

CAMARGO, L.S.A.; VIDOTTI, S.A.B.G. Arquitetura da informação: uma abordagem prática para o tratamento de conteúdo e interface em ambientes informacionais digitais. Rio de Janeiro: LTC, 2011.

CAMARGO, L.S.A. Metodologia de desenvolvimento de ambientes informacionais digitais a partir dos princípios da Arquitetura da Informação. 2010. 287f. Tese (Doutorado em Ciência da Informação) - Faculdade de Filosofia e Ciências, Universidade Estadual Paulista, Marília, 2010.

CAPURRO, R. Epistemologia e Ciência da Informação. 2003. Disponível em: <http://www.capurro.de/enancib_p.htm>. Acesso em: 10 mai. 2013.

CARTER, H. Information architecture. Work study, v. 48, n. 5, p.182185, 1999. Disponível em: <http://www.emeraldinsight.com/journals.htm? issn $=0043-8022$ \& volume $=48$ \&issue $=5$ \&articleid $=851315$ $\&$ show $=$ pdf $>$. Acesso em: 2 dez. 2013.

CASTELLS, M. A sociedade em rede. 8. ed. São Paulo: Paz e Terra, 1999.

CHIOU, F. We are all connected: the path from Architecture to Information Architecture, boxes and arrows. 2003. Disponível em: <http:// boxesandarrows.com/we-are-all-connected-the-path-from-architecture-to-information-architecture/>. Acesso em: 10 jan. 2012.

COOK, M.A. Building enterprise information architecture: reengineering information systems. Upper Saddle River: Prentice Hall, 1996.

DAHLBERG, I. Teoria do conceito. Ciência da informação, Brasília, v.7, n.2, p.101-7, 1978.

DELEUZE, G.; GUATTARI, F. O que é a filosofia? 2.ed. São Paulo: Editora 34, 2004.

DICKSON, G.W.; WETHERBE, J.C. The management of information system. New York: McGraw-Hill, 1985. 
DILLON, A. Information Architecture why, what $\mathcal{E}$ when? 2003. Disponível em: <http://www.asis.org/Conferences/Summit2000/dillon/>. Acesso em: 26 nov. 2011.

DUARTE, F. Arquitetura e tecnologias de informação: da Revolução Industrial à Revolução Digital. São Paulo: Annablume, 1999.

ECKERT-HOFF, B.M. Apresentação e Editorial. Revista de Estudos de Tecnologia de Informação e Comunicações. v.1, n.1, 2011. Disponível em: <http://www.anchieta.br/unianchieta/revistas/ubiquidade/Site/ubiquidade/pdf/Ubiq-N01-V01.pdf>. Acesso em: 1 fev. 2014.

EVERNDEN, R.; EVERNDEN, E. Third-generation information architecture. Communications of the ACM. v. 46, n. 3, p.95-98, 2003.

FARRADANE, J. Knowledge, information and Information Science. Journal of Information Science. v.2, p.75-80, 1980.

FREIRE, G.H. Ciência da Informação: temática, histórias e fundamentos. Perspectivas em Ciência da Informação. Belo Horizonte, v.11 n.1, p.6-19, jan./abr. 2006.

FROHMANN, B. Taking information policy beyond information science: applying the actor network theory. In: Annual Conference Canadian Association for Information Science, 23, 1995, Edmond, Alberta. Proceedings... Alberta, 1995. Disponível em: <http://www.cais-acsi.ca/proceedings/1995/frohmann_1995. pdf>. Acesso em: 10 mar. 2013.

GATTI, B.A. Pesquisa, Educação e Pós-Modernidade: confrontos e dilemas. Cadernos de Pesquisa. v.35, n.126, p.595-608, set./dez. 2005.

GIDDENS, A. Modernidade e identidade. Rio de janeiro: Zahar, 2002.

GONZÁLEZ DE GOMEZ, M.N. Metodologia de pesquisa no campo da Ciência da Informação. DataGramaZero - Revista de Ciência da Informação, v.1, n.6, dez. 2000.

HABERMAS, J. Discurso filosófico da modernidade. Lisboa: Dom Quixote, 1990.

HAGEDORN, K. The information architecture glossary. Argus Center for Information Architecture, 2000.

HALL, S. A identidade cultural na Pós-Modernidade. Rio de Janeiro: DP\&A, 2006.

HEARST, M. Search user interfaces. Oxford: Cambridge University Press, 2009.

HOUAISS, A.; VILLAR, M.S. Minidicionário Houaiss da língua portuguesa. 2.ed. Rio de Janeiro: Objetiva, 2004. 
HUBERT MILLER, D.; ARBOGAST, B. The IA of potentiality: Toward a grounded theory of information architecture philosophy, theory and research. Bulletin of the American Society for Information Science and Technology, v. 32, n. 6, p.10-12, 2006.

ILHARCO, F. Filosofia da informação: uma introdução à informação como fundação da acção, da comunicação e da decisão. Lisboa: Universidade Católica, 2003.

JANDL JUNIOR, P. Computação, Ubiquidade e Transparência. Revista de Estudos de Tecnologia de Informação e Comunicações. v.1, n. 1, 2011. Disponível em: <http://www.anchieta.br/unianchieta/revistas/ ubiquidade/Site/ubiquidade/pdf/Ubiq-N01-V01.pdf>. Acesso em: 1 fev. 2014.

JAPIASSU, H.; MARCONDES, D. Dicionário básico de filosofia. 4. ed. Rio de Janeiro: Jorge Zahar, 2006.

KAHN, P.; LENK, K. Website information architecture. Indianapolis: New Riders, 1998.

KOWALTOWSKI, D.C.C.K., et al. Reflexão sobre metodologias de projeto arquitetônico. Ambiente construído, v.6, n.2, p.7-19, 2008.

KUHN, T.S. A estrutura das revoluções científicas. 7. ed. São Paulo: Perspectiva, 2003.

KUNIAVSKY, M. Smart things: ubiquitous computer user experience design. Burlington: Morgan Kaufmann, 2010.

LEIS, H.R. Sobre o conceito de interdisciplinaridade. Caderno de pesquisa interdisciplinar em Ciências Humanas. n.73, p.3-22, 2005.

LEÓN, Rodrigo Ronda. Arquitectura de Información: análisis histórico-conceptual. No sólo usabilidade Journal, n.7, abr. 2008. Disponível em: <http://www.nosolousabilidad.com/articulos/ai_cc_informacion.ht historia_arquitectura_informacion.htmm>. Acesso em: 20 abr. 2013.

LIPOVETSKY, G.; CHARLES, S. Os tempos hipermodernos. São Paulo: Barcarolla, 2004.

LÖWY, M0. As aventuras de Karl Marx contra o Barão de Müchhausen: marxismo e positivismo na sociologia do conhecimento. 5.ed. São Paulo: Busca Vida, 1987.

LUNIN, L.F.; MARTIN, K.; HASTINGS, S.K. Design: Information technologies and creative practices. Journal of the American Society for Information Science and Technology, v.60, n.9, p.1847, 2009.

LYOTARD, J.-F. O pós-moderno. Rio de Janeiro: José Olympio, 1993. 
MACEDO, F.L.O. Arquitetura da informação: aspectos epistemológicos, científicos e práticos. 2005. 190 f. Dissertação (Mestrado em Ciência da Informação) - Faculdade de Ciência da Informação, Universidade de Brasília, Brasília, 2005.

MARTINS, G.A.; THEÓPHILO, C.R. Metodologia da investigação científica para ciências sociais aplicadas. São Paulo: Atlas, 2009.

MCGEE, J.V.; PRUSAK, L. Gerenciamento estratégico da informação. Rio de Janeiro: Campus, 1994.

MCLUHAN, M. A galáxia de Gutenberg: a formação do homem tipográfico. São Paulo: Edusp, 1972.

MILLER, P. Interoperability. What is it and why should I want it? Ariadne, n.24, 2000. Disponível em: <http://www.ariadne.ac.uk/ issue24/interoperability/>. Acesso em: 18 mar. 2007.

MORVILLE, P.; ROSENFELD, L. Information for Architecture for the Word Wide Web. 3.ed. Sebastopol, CA: O’Reilly, 2006.

NARDELLI, E.S. Arquitetura e projeto na era digital. Arquitetura e Revista, v.3, n.1, p.28-36, 2007.

NEGROPONTE, N. A vida digital. São Paulo: Companhia das Letras, 2008.

NIELSEN, J. Designing Websites with authority: secrets of an information architecture. Indianapolis: New Riders, 1998.

NIEMEYER, L. Design no Brasil: origens e instalação. 4. ed. Rio de Janeiro: 2AB, 2007.

OLIVEIRA, H.P.C. Arquitetura da informação pervasiva: contribuições conceituais. 2014. 202 f. Tese (Doutorado em Ciência da Informação) - Faculdade de Filosofia e Ciências, Universidade Estadual Paulista, Marília, 2014.

OLIVEIRA, H.P.C.; VIDOTTI, S.A.B.G. Arquitetura da informação digital: conexões interdisciplinares dentro da abordagem sistêmica. In: CAVALCANTE, L.E.; BENTES PINTO, V.; VIDOTTI, S.A.B.G. Ciência da informação e contemporaneidade: tessituras e olhares. Fortaleza: UFC, 2012. p.184-202.

OLIVEIRA; H.P.C.; VIDOTTI, S.A.B.G. O ensino de Arquitetura da Informação e organização/representação da informação digital: uma análise curricular dos cursos de Biblioteconomia do Brasil. In: I Congresso Isko Espanha e Portugal XI Congreso Isko España. 1., 2013. Anais... Porto: Universidade do Porto, 2013. Disponível em: <http:// http://www.youblisher.com/p/749221-I-Congresso-ISKO-Espa- 
nha-e-Portugal-XI-Congreso-ISKO-Espana/>. Acesso em: 1 dez. 2013.

PAKE, G.E. Research at Xerox PARC: a founder's assessment. IEEE Spectrum, 1985. In: HEARST, M.A. Research in Support of Digital Libraries at Xerox PARC. Part I: The Changing Social Roles of Documents. D-Lib Magazine, May 1996. Disponível em: <http://www. nosolousabilidad.com/articulos/historia_arquitectura_informacion. htm\#sthash.zYXIMbIU.dpuf>. Acesso em: 19 mar. 2012.

PINHEIRO, L.V.R. Processo evolutivo e tendências contemporâneas da Ciência da Informação. Informação $\mathcal{E}$ Sociedade: Estudos, João Pessoa, v.15, n.1, p.13-48, jan./jun. 2005.

PINTO, A.V. O conceito de tecnologia. Rio de Janeiro: Contraponto, 2005. POTENTE, D.; SALVINI, E. Apple, Ikea and their integrated architecture. Bulletin of the American Society for Information Science and Technology, v. 35, n.4, p.32-42, 2009.

PREECE, J.; ROGERS, Y.; SHARP, H. Design de interação: além da interação homem-computador. Porto Alegre: Bookman, 2005.

RAMALHO, R.A.S.; VIDOTTI, S.A.B.G.; FUJITA, M.S.L. Web semântica: uma investigação sob o olhar da Ciência da Informação. DataGramaZero, v.8, n.6 dez. 2007. Disponível em: <http://www. dgz.org.br/dez07/F_I_aut.htm>. Acesso em: 10 out. 2011.

RESMINI, A; ROSATI, L. Pervasive information architecture: designing cross-channel user experiences. Burlington: Elsevier, 2011.

ROSENFELD, L.; MORVILLE, P. Information Architecture for the World Wide Web. Beijing: O'Reilly, 1998.

SANTARÉM SEGUNDO, J.E.; VIDOTTI, S.A.B.G. Representação iterativa e folksonomia assistida para repositórios digitais. Liinc em Revista, v.7, n.1, março 2011, Rio de Janeiro, p.283-300.

SANTOS, B.S. Um discurso sobre as ciências. Porto: Afrontamento, 1987. Um discurso sobre as ciências na transição para uma ciência pós-moderna. Estudos avançados. v.2, n.2, p.46-71, 1988.

SANTOS, P.L.V.A.C.; VIDOTTI, S.A.B.G. Perspectivismo e Tecnologias de Informação e Comunicação: acréscimos à Ciência da Informação? DataGramaZero: revista de Ciência da Informação, Rio de Janeiro, v.10, n.3, jun. 2009. Disponível em: <http://dgz.org.br/ jun09/Art_02.htm \>. Acesso em: 10 jul. 2013.

SARACEVIC, T. Ciência da informação: origem, evolução e relações. Perspectivas em Ciência da Informação. Belo Horizonte, v.1, n.1, p.4162, jan./jun., 1996. 
SAYÃO, L.F.; MARCONDES, C.H. O desafio da interoperabilidade e as novas perspectivas para as bibliotecas digitais. Transinformação, v.20, n.2, 2012. Disponível em: <http://200.18.252.94/seer/index. $\mathrm{php} /$ transinfo/article/download/530/510 >. Acesso em: 2 fev. 2014.

SILVA, A.M. A Informação: da compreensão do fenômeno e construção do objecto cientifico. Porto: Afrontamento, 2006.

SILVA, A.M.; RIBEIRO, F. Das "Ciências" Documentais à Ciência da Informação: ensaio epistemológico para um novo modelo curricular. Porto: Afrontamento, 2002.

Paradigmas, serviços e mediações. Recife: Néctar, 2011.

SQUIRRA, S. Sociedade do conhecimento. In: MARQUES DE MELO; SATHER (orgs.). Direitos à comunicação na sociedade da informação. São Bernardo do Campo: Editora da UMESP, 2005.

TAYLOR, A.G. The organization of information. 2.ed. London: Westport Connecticut, 2004.

TOSETE HERRANZ, F.; RODRÍGUEZ MATEOS, D. Arquitectura de la información y el diseño de sedes web. In La información en la posmodernidad: la sociedad del conocimiento en España e Iberoamérica. Madrid: Centro de Estudios Ramón Areces, 2004. p.205-17.

TRAMULLAS, J. Documentos y servicios digitales: de la usabilidad al diseño centrado en el usuario. El profesional de la información, v.12, n.2, p.107-10, 2003.

TURBAN, E.; MCLEAN, E.; WETHERBE, J.C. Information technology for management. Indianapolis: Wiley, 1996.

UKOLN. Interoperability focus: looking at interoperability. 2005. Disponível em: <http://www.ukoln.ac.uk/interop-focus/about/ leaflet. html>. Acesso em: 1 fev. 2014.

VECHIATO, F.L. Encontrabilidade da informação: contributo para uma conceituação no campo da Ciência da Informação. 2013. 206 f. Tese (Doutorado em Ciência da Informação) - Faculdade de Filosofia e Ciências, Universidade Estadual Paulista, Marília, 2013.

VIDOTTI, S.A.B.G.; OLIVEIRA, H.P.C; LIMA, I.F. Ensino de tecnologias de informação e comunicação: um diagnóstico nos cursos de graduação em Biblioteconomia, Arquivologia e Museologia do Brasil. In: Enancib - Encontro Nacional de Pesquisa em Ciência da Informação, 14., 2013 Anais eletrônicos... Florianópolis: Ancib, 2013. Disponível em: <http://enancib.sites.ufsc.br/index.php/ enancib2013/XIVenancib/schedConf/presentations>. Acesso em: 23 nov. 2013. 
VIDOTTI, S.A.B.G.; CUSIN, C.A.; CORRADI, J.A.M. Acessibilidade digital sob o prisma da Arquitetura da Informação. In: GUIMARÃES, J.A.C.; FUJITA, M.S.L. Ensino e pesquisa em biblioteconomia no Brasil: a emergência de um novo olhar. São Paulo: Cultura Acadêmica, 2008.

VILLAS-BOAS, A. O que é [e o que nunca foi] design gráfico. Rio de Janeiro: 2AB, 2000.

VOGEL, D.R.; WETHERBE, J.C. University planning: Developing a long-rage Information Architecture. Planning and Changing. fall 1984. Information architecture: sharing the sharable resource. CAUSE/ EFFECT, 14, p.4-9, 1991.

VON BERTALANFFY, L. Teoria geral dos sistemas. São Paulo: Vozes, 1975.

WEITZMAN, L.M. The architecture of information: interpretation and presentation of information in dynamic environments. 1995. $152 \mathrm{f}$. Tese (Doutorado) - Massachusetts Institute of Technology, Massachusetts Institute of Technology, Cambridge, 1995. Disponível em: $<$ http://citeseerx.ist.psu.edu/viewdoc/download;jsessionid=7D93C 33E6C04D3D70DD1B7D793035CF2?doi=10.1.1.132.4379\&rep=r ep1\&type $=$ pdf $>$. Acesso em: 25 out. 2013.

The world is not a desktop. In: ACM Interactions. v.1, n.1, p.7-8, 1994.

WETHERBE, J.C.; DAVIS, G.B. Developing a long-range information architecture. In: National Computer Conference, 1983, Anaheim. Proceedings... Anaheim: ACM, 1983. p.261-9. Disponível em: <http:// dl.acm.org/citation.cfm?id=1500709 >. Acesso em: 2 dez. 2013.

Information Architectures and data modelling: cornerstone for succeeding in the information society. In: International Conference On Entity-Relationship Approach, 6th, 1987. Proceedings... NorthHolland Publishing Co., 1987. Disponível em: <http://www.bibsonomy.org/bibtex/243185ccd91e14dc4a2511ac1c7d69bd1/dblp>. Acesso em: 2 dez. 2013.

WILSON, J. Pensar com conceitos. São Paulo: Martins Fontes, 2001. WURMAN, R.S. Information architects. Zurich: Graphis, 1996. Ansiedade de Informação 2. 2. ed. São Paulo: Editora de Cultura, 2005. 


\section{SOBRE OS AUTORES}

Henry Poncio Cruz de Oliveira. Físico (2007) pela Universidade Federal da Paraíba (UFPB). Mestre (2010) em Ciência da Informação pelo Programa de Pós-Graduação em Ciência da Informação da Universidade Federal da Paraíba (UFPB). Doutor (2014) em Ciência da Informação pelo Programa de Pós-Graduação em Ciência da Informação da Universidade Estadual Paulista Júlio de Mesquita Filho (Unesp-Marília). Professor adjunto do Departamento de Ciência da Informação da Universidade Federal da Paraíba (UFPB). Foi docente (2010-2015) da Universidade Federal do Cariri (UFCA), atuou como coordenador de Inovação na Pró- Reitoria de Pesquisa e Inovação da UFCA, implantou o Portal de Periódicos da UFCA e a plataforma editorial de e-books da UFCA.

Silvana Aparecida Borsetti Gregorio Vidotti. Licenciada em Matemática (1986) pelo Instituto de Biociências, Letras e Ciências Exatas da Unesp. Especialista em Ciência da Computação (1987) pelo Instituto de Ciências Matemáticas de São Carlos, USP. Mestre em Ciências - área de concentração Ciências da Computação e Matemática Computacional (1993) - pelo Instituto de Ciências Matemáticas de São Carlos. Doutora em Educação - área de concentração Educação Brasileira (2001) - pela Faculdade de Filosofia e Ciências da Unesp. Professora assistente doutora em regime 
de dedicação integral à docência e à pesquisa da Unesp-Marília, Departamento de Ciência da Informação e Programa de Pós-Graduação em Ciência da Informação. Assessora da Pró-Reitoria de Pós-Graduação da Unesp (Propg) desde 2013. Pesquisadora de Produtividade-PQ-CNPq.

Virgínia Bentes Pinto. Bacharel (1979) em Biblioteconomia pela Universidade Federal do Ceará (UFG). Mestre (1989) em Ciências da Informação pela Universidade Federal de Minas Gerais. Doutora (1999) em Sciences de l'Information et de la Communication - Université Stendhal-Grenoble-3-França. Pós-Doutora em Filosofia - Tratamento cognitivo da informação - Laboratoire d'analyse cognitive de l'information (Lanci) Université du Quebec à Montreal-Dept. (2006). Estágio pós-doutoral no Instituto de Linguística Aplicada (Iula) da Universidade Pompeu Fabra- Barcelona e Cátedra Interuniversitária de Derecho y Genoma Humano - Universidad de Deusto-Pais Basco (2013). Professora Associada no Departamento de Ciências da Informação da Universidade Federal do Ceará (UFC). Coordenadora do Doutorado Interinstitucional em Ciência da Informação - Unesp-DCIMarília/UFC-DCINF. Colaboradora do Programa de Pós-Graduação em Ciência da Informação das Universidades Estadual Paulista Júlio de Mesquita Filho (Unesp) e Universidade Federal da Paraíba (UFPB). Pesquisadora de Produtividade-PQ-CNPq. 
SOBRE O LIVRO

Formato: $14 \times 21 \mathrm{~cm}$

Mancha: 23,7 x 42,5 paicas

Tipologia: Horley Old Style 10,5/14

EQUIPE DE REALIZAÇÃO

Coordenação Geral

Atarukas Studio 